This PDF is a selection from a published volume from the National Bureau of Economic Research

Volume Title: Strained Relations: U.S. Foreign-Exchange Operations and Monetary Policy in the Twentieth Century

Volume Author/Editor: Michael D. Bordo, Owen F. Humpage, and Anna J. Schwartz

Volume Publisher: University of Chicago Press

Volume ISBN: 0-226-05148-X, 978-0-226-05148-2 (cloth);

978-0-226-05151-2 (elSBN)

Volume URL: http://www.nber.org/books/bord12-1

Conference Date: n/a

Publication Date: February 2015

Chapter Title: U.S. Intervention during the Bretton Woods Era, 19621973

Chapter Author(s): Michael D. Bordo, Owen F. Humpage, Anna J. Schwartz

Chapter URL: http://www.nber.org/chapters/c13540

Chapter pages in book: (p. $120-209)$ 


\section{US Intervention during the Bretton Woods Era, 1962-1973}

There is little evidence . . of any systematic effort by the Federal Reserve to conduct monetary policy in a manner consistent with the requirements of a fixed exchange rate system. And, there is no evidence that any of the administrations objected to this neglect.

—Allan H. Meltzer (1991, 55)

\subsection{Introduction}

The Bretton Woods fixed-exchange-rate system attempted to maintain par values and promoted free cross-border financial flows while still allowing countries to promote domestic macroeconomic objectives, notably full employment. It hoped to do so by allowing countries to alter parities in the face of fundamental disequilibria and to temporarily impose restraints on financial flows. Whether such a system ever offered a long-term, viable solution to the fundamental trilemma of international finance seems unlikely, but more immediate flaws shortened whatever longevity Bretton Woods may have had.

By the early 1960s, as Bretton Woods became fully functional, the amount of US dollar claims held abroad began to exceed the US government's stock of gold. This situation implied that the United States could not fully keep its pledge to convert dollars into gold at the official price and raised fears of a dollar devaluation. These dollars, once necessary to maintain the system, were becoming a source of instability. By the late 1960s, a rising US inflation rate and speculative flows in anticipation of cross exchange-rate adjustments were adding even more unwanted dollars to many foreign centralbank portfolios.

Hoping to neutralize the growing speculative activity, the US Treasury began intervening in the foreign exchange market in March 1961. A year later, the Federal Reserve also began foreign-exchange-market operations primarily aimed at forestalling foreign central-bank claims on the US gold stock. These operations were stopgap, which seemed appropriate in the early 1960s. United States administrations blamed transitional factors, largely associated with the postwar global recovery and military needs, for much 
of the pressure on the US balance of payments, so mechanisms designed to buy time for an inevitable adjustment seemed suitable.

By the late 1960s, however, US inflation aggravated the structural weaknesses of Bretton Woods. Increasingly the situation appeared to be a dollar problem. Within the Bretton Woods framework, either the United States had to forgo its domestic growth and employment goals or the other developed countries had to sacrifice their inflation objectives. Ultimately, elected officials were unwilling to do so and jettisoned the fixed-parity framework. The United States closed its gold window in August 1971, and generalized floating commenced in March 1973. As a solution to the fundamental trilemma, Bretton Woods failed.

The US foreign-exchange operations between 1961 and 1973 were paradoxically both a short-term success and a long-term failure. By raising the costs of speculation and by providing cover for unwanted, temporary, and ultimately reversible dollar flows, these operations forestalled US gold losses and boosted credibility in the Bretton Woods system, but to the extent that these operations substituted for more fundamental adjustments, they only postponed and heightened the inevitable collapse of Bretton Woods. In addition, the institutional arrangements girding these foreign-exchange operations raised important issues about the Federal Reserve's independence, which would often resurface over the next twenty-five years or so.

\subsection{Bretton Woods: Prospects and Problems}

The officials who signed the International Monetary Fund (IMF) Articles of Agreement at Bretton Woods, New Hampshire, in July 1944 envisioned an international financial system based on close cooperation that would foster stability, promote full employment, and prevent a return to the beggarthy-neighbor policies of the early 1930s. ${ }^{1}$ Under the agreement, the United States pegged the dollar to gold at $\$ 35$ per ounce and pledged to buy and sell the metal freely at this price. Other nations established parities for their currencies relative to the dollar and were obliged to keep their exchange rates within a 1 percent band around the central value through foreignexchange interventions, restraints on financial flows, and presumably the adoption of compatible macroeconomic policies. ${ }^{2}$ When faced with a transitory balance-of-payments problem, a country with insufficient reserves to finance its intervention could borrow from the IMF instead of quickly instituting deflationary macroeconomic programs. The ability to borrow reserves would also lessen the deficit country's incentive to impose trade restraints or exchange controls on current-account transactions.

Exchange rates were not immutable under the Bretton Woods system. After IMF consultation and approval, countries facing a "fundamental disequilibrium" in their balance of payments could adjust their parities. In principle, the IMF could also insist that the country adopt macroeconomic 
policies consistent with any exchange-rate realignment, but the IMF lacked a credible enforcement mechanism. Deficit countries, which felt pressures to adjust more immediately than surplus countries, postponed devaluation to avoid the stigma - one of "failed economic policies" - that devaluation carried.

Although the Bretton Woods system began operating in 1946, European currencies remained inconvertible for current-account transactions until late 1958, and the Japanese yen stayed similarly inconvertible until 1964. Initially, these war-ravaged countries maintained inconvertible currencies as a means of limiting their current-account deficits. Most lacked sufficient international reserves to sustain growing deficits for long, even after allowing for IMF credits. In 1949, the situation compelled many European countries to devalue their currencies relative to the dollar. France devalued in 1957 and again as late as $1959 .^{3}$

During the 1950s, however, the international position of the war-torn industrialized countries greatly improved. Foreign productivity and competitiveness recovered. Government grants and long-term financial outflows from the United States helped the recovery process. The resulting US balance-of-payments deficits provided a source of much needed international reserves to accommodate expanding international trade. A general quota increase in 1959 also augmented IMF funds that were available for temporary balance-of-payments assistance. By the late 1950s, more than a decade after its beginning, the Bretton Woods exchange-rate system became fully functional.

At about the same time, however, markets and central banks were quickly losing confidence in the viability of the official dollar gold price, the keystone of the entire Bretton Woods structure. Two interrelated developments proved particularly problematic: Triffin's paradox, which describes a fundamental defect in gold-exchange standards like Bretton Woods, and an accelerating US inflation rate after 1965. A third factor, which acquired importance only in conjunction with the previous two, stemmed from inevitable cross-rate adjustment problems among participating countries other than the United States. We describe each of these factors in turn.

\subsubsection{Triffin's Paradox}

The framers of Bretton Woods set the official price of gold at $\$ 35$ per ounce, the same price that the US Gold Reserve Act of 1934 had established. Because of inflation during World War II and shortly thereafter, this official price became too low in real terms to induce sufficient gold production for expanding reserve needs (see Bordo 1993; James 1996; Meltzer 1991). By the early 1950s, the real price of gold was only half of its 1934 value (see figure 4.1). ${ }^{4}$ Between 1948 and 1958, the free world's gold stock increased only 16 percent while its imports rose 68 percent (Triffin 1960, table 14, 72-73).

The United States, as noted, provided needed liquidity by running per- 


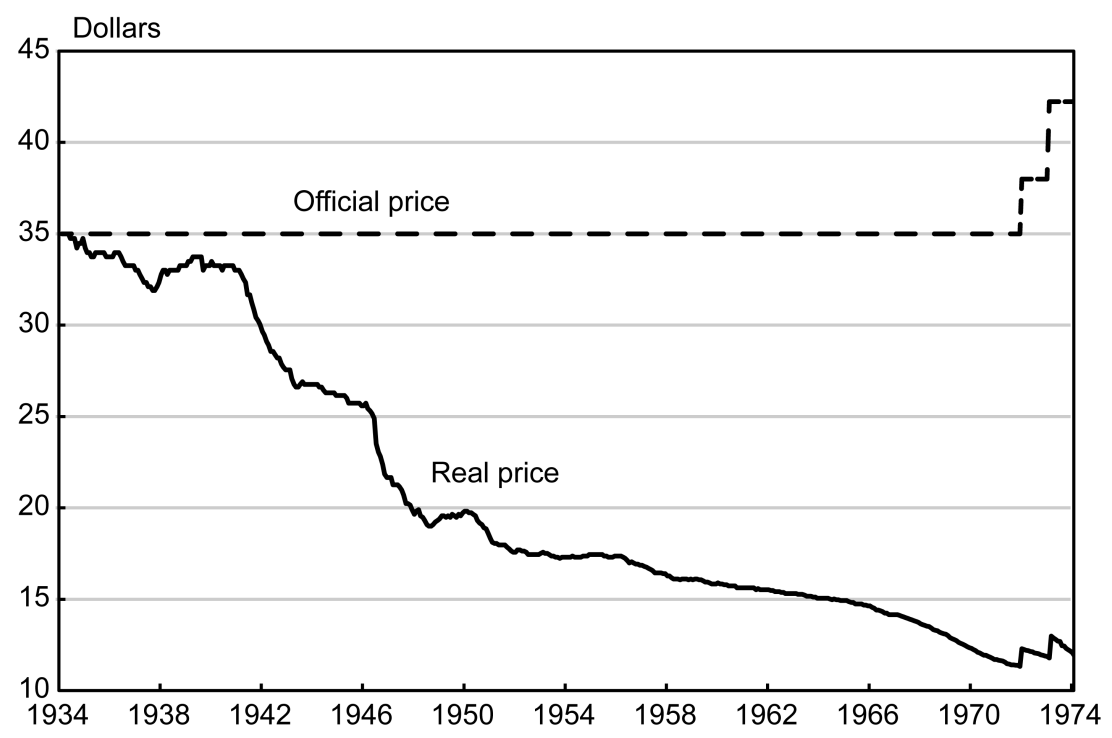

Fig. 4.1 Official and real gold prices, February 1934-December 1973

Note: Real gold price constructed with US Consumer Price Index (CPI) from the US Bureau of Labor Statistics.

sistent balance-of-payments deficits. Between 1950 and 1957, these deficits averaged $\$ 1.3$ billion per year, as government grants, private remittances, and long-term financial outflows typically exceeded surpluses elsewhere in the accounts (figure 4.2). ${ }^{5}$ Neither the United States nor the international financial community seemed to view these deficits with much concern because they stemmed from postwar redevelopment efforts and from the provision of military security. Without the international reserves that these deficits provided, the postwar recovery of global trade and world economic activity would have proceeded more slowly, because countries facing even temporary balance-of-payments deficits would quickly need to deflate, devalue, or impose disruptive trade and financial restraints.

By the early 1960s, however, the total external dollar liabilities associated with the persistent US balance-of-payments deficits began to exceed the US gold stock, implying that the United States could not completely fulfill its obligation to sell gold at the official price (see figure 4.3). ${ }^{6}$ The very act of providing needed liquidity was itself creating uncertainty about the longterm viability of the parity structure. This was Triffin's paradox (Triffin, 1960). At the time, however, few interpreted the situation as inevitably leading to the demise of the Bretton Woods system.?

An outflow of gold accompanied the US balance-of-payments deficits during the 1950s, but it seemed a reasonable reversal of the substantial- 


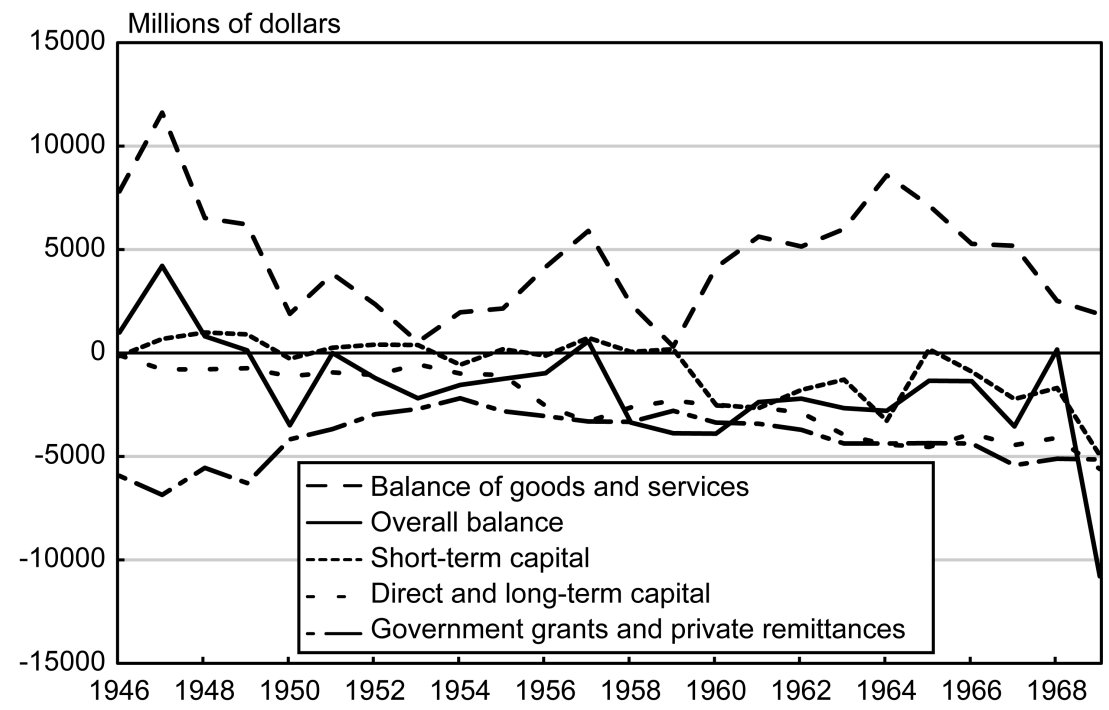

Fig. 4.2 US balance of payments trends, 1946-1969

Note: Data are from the US Department of Commerce.

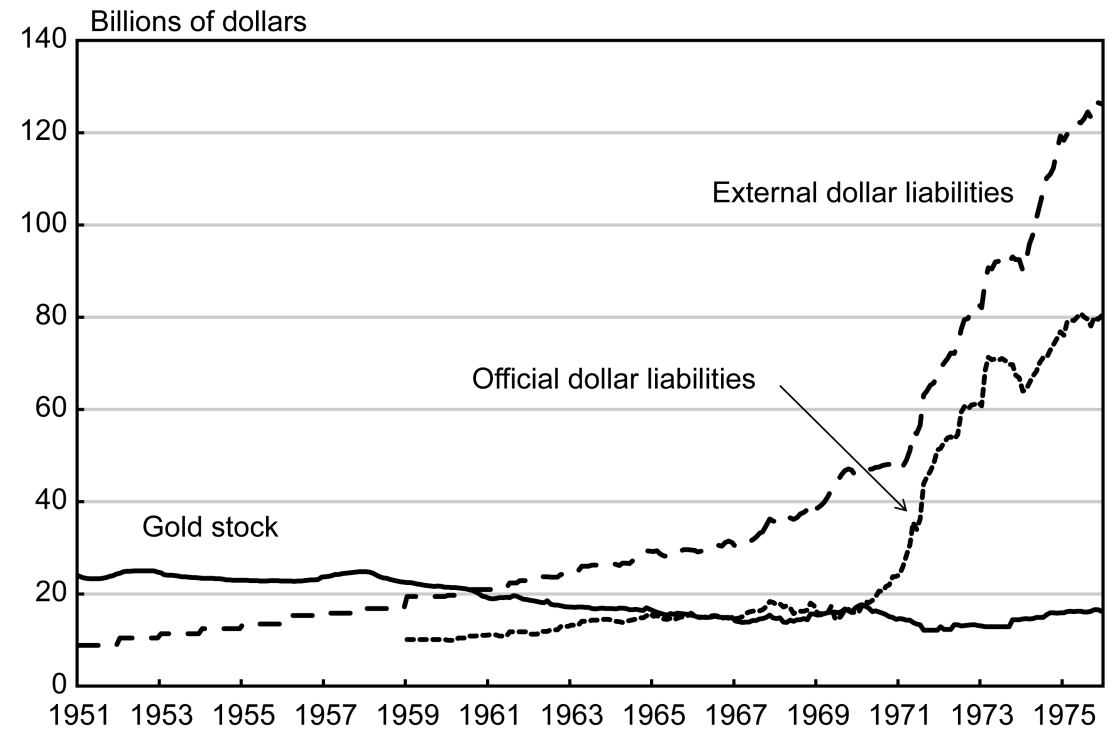

Fig. 4.3 US monetary gold stock and external liabilities, 1951-1975

Note: Data from the Board of Governors of the Federal Reserve System. 


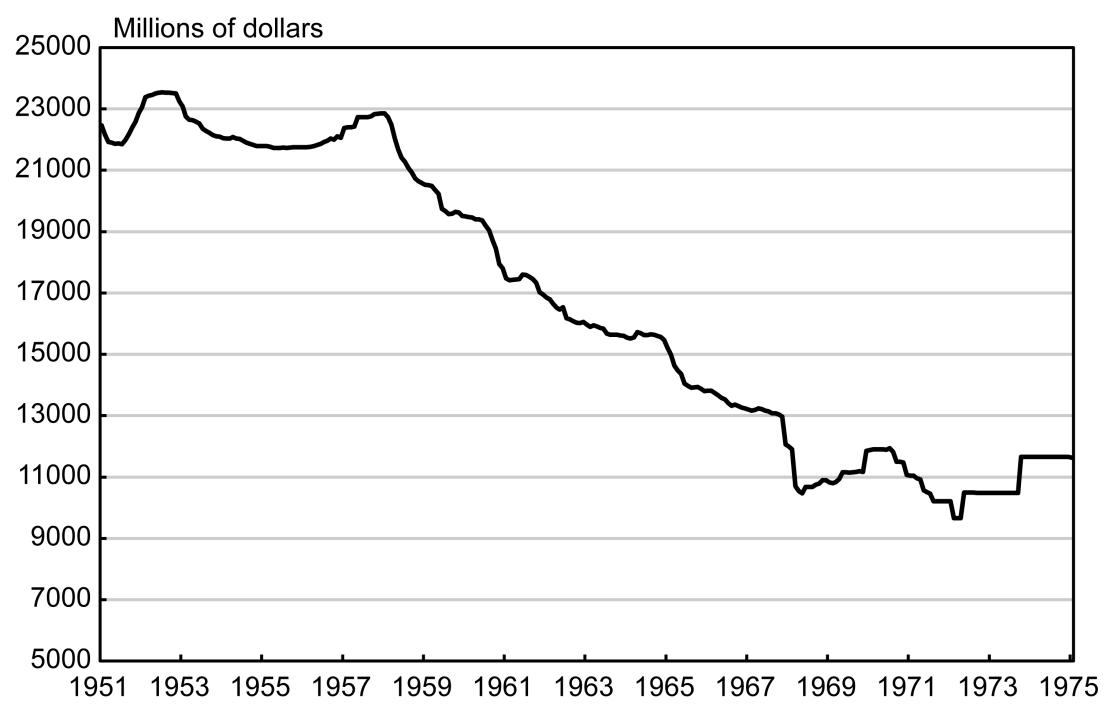

Fig. 4.4 US monetary gold stock, 1951-1975

Note: Data are from the Board of Governors of the Federal Reserve System.

largely safe-haven - gold acquisitions that the United States experienced in the 1930s and 1940s. The United States, which held 60 percent of the world's gold reserves in 1950, lost only \$213 million worth of gold on average each year between 1950 and 1957 (see figure 4.4). ${ }^{8}$ During that time, foreign countries increased their gold reserves mainly out of free-world gold production and through small purchases from the Soviet Union. In addition, the IMF sold the United States $\$ 800$ million worth of gold between 1951 and 1957 (Board of Governors 1963, 422).

Between 1958 and 1960, however, US balance-of-payments deficits widened to $\$ 3.7$ billion per year on average as surpluses on US goods and services trade narrowed slightly and as long-term financial outflows increased sharply. The most disturbing aspect of the expanding US balanceof-payments deficits, however, occurred with respect to short-term financial flows beginning in 1960. Heretofore, the United States had typically experienced small short-term financial inflows (including unrecorded items), but in 1960 the country witnessed a large outflow of nearly $\$ 2.5$ billion. Although US balance-of-payments deficits narrowed somewhat in 1961 and 1962, substantial outflows of short-term financial capital, often motivated by exchange-rate concerns, generally persisted.

Between 1958 and 1962, the average US gold loss increased sixfold to nearly $\$ 1.4$ billion per year. The US gold stock declined by $\$ 6.8$ billion or 30 percent as foreign countries converted dollar reserves into gold. ${ }^{9}$ The heavy gold losses would not have been so disturbing to US policymakers if 
they had not been accompanied by evidence of a run on the dollar. Foreign monetary authorities were not only converting new acquisitions of dollars into gold, but they were also converting - or planning to convert-a substantial portion of their existing dollar balances (FOMC Minutes, 10 January 1961,10$)$.

Between 1957 and 1962, the proportion of international reserves held in gold by noncommunist countries increased from 45 percent to 49 percent (Board of Governors 1963, 423). European countries, particularly France, Italy, and Germany, accounted for almost all of this gain; most other countries kept the share of their gold reserves fairly constant (Board of Governors 1963, 424). Despite the accelerated gold losses, the United States still held $\$ 16$ billion worth of gold reserves in 1962, approximately two-fifths of the world's gold stock. ${ }^{10}$

On 20 October 1960, the price of gold on the London market shot above the official US gold price to $\$ 40$ per ounce, as private demand for gold reached record levels. This was a critical juncture in the Bretton Woods era. Given the inelastic supply of gold at the official price, Bretton Woods was unworkable without dollar reserves, but with additional dollar reserves, Bretton Woods became increasing unstable. Henceforth, as we will document, both gold and foreign-exchange markets would remain vulnerable to speculative pressures as suggested by Triffin's paradox.

\subsubsection{US Inflation after 1965}

The corrosive inevitabilities that Triffin explained became substantially worse after 1965 as US inflation accelerated. Inflation in the United States rose from around 1 percent in late 1964 to 6 percent in mid-1970. Inflation then moderated, following a recession that year, to 4.6 percent in August 1971, when President Nixon ended convertibility, and then to a low of 2.7 percent in June 1972. Thereafter, inflation rose again, reaching 4.6 percent in March 1973 when Bretton Woods collapsed. Inflation in the United States put additional unwanted dollars in the coffers of foreign central banks that intervened to prevent their currencies from appreciating against the dollar. ${ }^{11}$ In that way, inflation aggravated Triffin's paradox and weakened Bretton Woods. Eventually, a loss of credibility in US monetary policy and a fear of importing US inflation would be a key factor in the demise of the Bretton Woods system.

Ideally, defining the dollar in terms of gold should have constrained inflation in the United States. A higher inflation rate could worsen the US balance of payments and cause further gold losses, which eventually would undermine the official gold price. Before 1958, Bretton Woods never posed a significant restraint on US monetary policy because of the growing global demand for dollar reserves and the large US gold stock. In the first half of the 1960 s, by contrast, the Bretton Woods system had some influence on 
US monetary-policy decisions. ${ }^{12}$ Thereafter, however, its influence weakened. Balance-of-payments considerations still arose within the FOMC, and during crisis periods, such as the devaluation of the British pound in 1967, they directly shaped US monetary policy. But, once the Treasury (with the Federal Reserve's help) took an active role in the area of emerging international-finance problems, the FOMC saw the balance of payments as primarily a Treasury concern and focused on domestic objectives (see Bordo and Eichengreen 2013).

While the weakening of the Bretton Woods constraint freed the Federal Reserve to pursue domestic economic objectives, it does not explain why the Federal Reserve was unable to maintain price stability. Economists have offered various explanations, which we discuss in chapter 5. Basically, however, inflation resulted because policymakers and many academic economists adopted an economic framework that deemphasized the role of money in the inflation process (see Hetzel 2008; Meltzer 2005, 2009a). For the most part, money was to support fiscal policies, which led in the management of aggregate demand. Moreover, many policymakers saw unemployment as a more critical social problem than inflation and were willing to accept higher inflation if it lowered the unemployment rate. Whatever the underlying source, US inflation worsened Triffin's paradox and accelerated the demise of Bretton Woods.

\subsubsection{Cross-Rate Adjustment Problems}

A third shortcoming of the Bretton Woods system that aggravated Triffin's paradox arose because cross exchange rates did not quickly adjust to balance-of-payments disequilibria. When both Germany and the United Kingdom pegged to the dollar, the mark-pound cross rate was also fixed. Although cross-rate-adjustment problems arose from economic developments within specific foreign countries, they contributed to the dollar's difficulties because of the dollar's role as the key international reserve and vehicle currency. Deficit countries defended their pegs by selling US dollars, while surplus countries defended their pegs by buying dollars. Financial funds flowed from deficit countries to surplus countries through dollars, adding to the large, often unwanted, dollar positions of surplus countries and creating inflationary pressures in these countries. Speculators (or their banks) fearing a pound devaluation, for example, would first sell pounds for dollars and then dollars for a strong currency, like Swiss francs or German marks. Dollars, not pounds, flowed into these countries. Many surplus countries, like Switzerland, strictly limited the ratio of dollar reserves to gold reserves in their portfolios and would sell unwanted dollars to the United States. The cross-rate-adjustment problem, notably among the United Kingdom, Germany, and France created uncertainty about the entire Bretton Woods parity structure, as we illustrate below. 


\subsection{The Policy Dilemma}

If the emerging US balance-of-payments problems were indeed evidence of a fundamental disequilibrium, the United States had to undertake a real dollar depreciation. ${ }^{13}$ Hemmed in by the perception of persistently weak domestic demand, constrained by the dollar's unique role in the Bretton Woods system, and still uncertain about the true underlying nature of recent balance-of-payments developments, none of the standard methods for achieving a real dollar depreciation seemed viable or even appropriate to US policymakers. Instead, policymakers in the early 1960s opted for a number of stopgap policies, of which exchange-market intervention became the most enduring.

The Eisenhower and Kennedy administrations attributed the worsening US balance-of-payments position between 1957 and 1962 to transitory factors stemming from US military and economic aid commitments, recent cyclical developments, and the reemergence of Western Europe and Japan as global competitors. In response to these developments, the United States undertook a series of policy initiatives to hasten adjustment in the US trade and long-term financial accounts and to improve the operation of the international financial system. These initiatives, however, suggest that US policymakers did not view the current situation as critical or enduring.

United States policymakers also appreciated that with the maturation of the Bretton Woods system-economic recovery abroad, growing currency convertibility, and an adequate pool of liquidity - short-term financial flows could henceforth be more sensitive to international interest-rate differentials and exchange-rate uncertainty. They seemed to believe, however, that once the transitory adjustments to the US trade and long-term financial accounts were complete, credibility in the dollar would strengthen. After all, reserve gains in France and Italy since 1957 illustrated how quickly countries' international positions could change (Board of Governors 1963, 421-28). Strengthened credibility in the dollar would lessen the problem of short-term financial flows.

Even if US policymakers had fleetingly glimpsed emerging events as evidence that the US balance-of-payments position was fundamentally unsustainable, they were unwilling to make the appropriate policy adjustments in the early 1960s. A fundamental disequilibrium would imply that the dollar was overvalued on a real basis and that a real depreciation was necessary to restore equilibrium to the US balance of payments. The United States could achieve a real depreciation only through one, or some combination, of four mechanisms: a nominal dollar devaluation, a deflation in the United States, an inflation in the rest of the world, or a general revaluation of foreign currencies. Whereas US policymakers might have welcomed a higher rate of inflation abroad, and whereas they actively encouraged the revaluation of currencies in surplus countries, they were unwilling to alter the official 
gold price or to dampen aggregate demand in the United States for balanceof-payments purposes. ${ }^{14}$

A one-time nominal dollar devaluation was simply out of the question. By imposing wealth losses on central banks and individuals that held open positions in US dollars, any dollar devaluation could forever threaten the reserve-currency status of the US dollar. Moreover, short-term financial outflows might actually increase if a one-time devaluation proved insufficient for balance-of-payments adjustment, or if other countries simultaneously devalued their currencies against the dollar. The United States also opposed an increase in the gold price because it would specifically benefit South Africa and the Soviet Union, the two major gold producers (Task Force 1990b, Paper no. 3, 10). For these reasons, the Kennedy administration went to considerable lengths to convince markets of its commitment to the official gold price.

Similarly, administration and Federal Reserve policymakers were unwilling to dampen aggregate demand for balance-of-payments purposes. The president of the Federal Reserve Bank of Atlanta, Malcolm Bryan, seems to have typified the view, at least as it prevailed among many Federal Reserve policymakers:

the last time the [Federal Reserve] System reacted in its policy decisions primarily because of foreign developments was . . in 1931. At that time, with unemployment constantly increasing and with every element in the domestic economy calling for ease, the System responded by tightening in order to protect the gold supply. (FOMC Minutes, 10 January 1961, 41)

He, like many other policymakers, feared a replay of the past. The United States had experienced back-to-back recessions from the third quarter of 1957 through the first quarter of 1958, and again from the second quarter of 1960 through the first quarter of 1961. These cost the Republicans the election in 1960. Kennedy pledged to "get the country moving again." The unemployment rate remained stubbornly high, and President Kennedy's Council of Economic Advisors expected US economic activity to remain below its potential level through 1963. Consequently, policymakers would not undertake deflationary macroeconomic programs.

While the overall thrust of macroeconomic policy was to promote the growth of aggregate demand, international considerations did exert some limited influence on the contours of both fiscal and monetary policies in the early 1960s. Under the Kennedy administration, the federal budget shifted from a surplus of $\$ 0.3$ billion in 1960 to deficits of $\$ 3.4$ billion in $1961, \$ 7.2$ billion in 1962, and $\$ 4.8$ billion in $1963 .{ }^{15}$ In 1962 , the administration introduced an investment tax credit and liberalized depreciation allowances primarily to spur aggregate demand, but the administration also thought that these tax cuts could improve the country's international competitiveness.

For its part, the Federal Open Market Committee (FOMC) eased policy in 
1960 , initially by cutting the official discount rate, then by injecting reserves through open-market operations and by allowing banks to count vault cash as reserves. Thereafter, the committee held course through 1963-sometimes under pressure from the Kennedy administration - and then tacked slowly in the other direction through 1965 (figure 4.5). In 107 policy decisions between the 13 September 1960 and the 1 November 1966 FOMC meetings, the committee voted ninety-two times to maintain the current stance of policy. ${ }^{16}$ On fifteen occasions over this period, the FOMC voted for additional restraint. Most of the decisions to tighten were undertaken for a mixture of domestic and international considerations, with the domestic situation undoubtedly holding more weight. ${ }^{17}$ On only four occasionsthree in 1963 and one in late 1964 — did the committee tighten policy solely for international considerations. During the early 1960s, domestic considerations usually motivated committee member dissents for a looser policy, while international consideration usually motivated committee member dissents for a tighter policy. Nevertheless, monetary policy seemed relatively accommodative until late 1964 and 1965 (see figure 4.6).

Short-term capital outflows did affect how the Federal Reserve conducted monetary policy in the early 1960 s, even if they did not alter the overall thrust of monetary policy very much. Since April 1953, except for brief periods of extreme market disorder, as in 1955 and 1958, the Federal Reserve had operated under a "bills only" doctrine; that is, the Federal Reserve con-

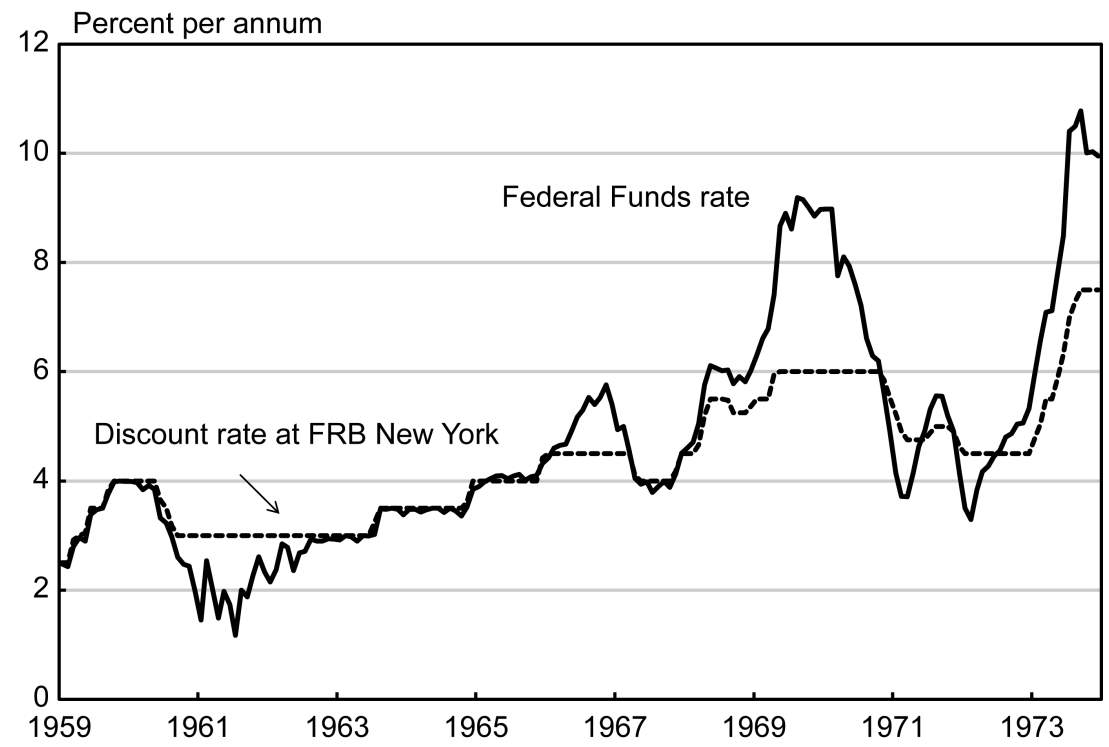

Fig. 4.5 Federal Reserve policy rates, 1959-1973

Note: Data are from the Federal Reserve System. 


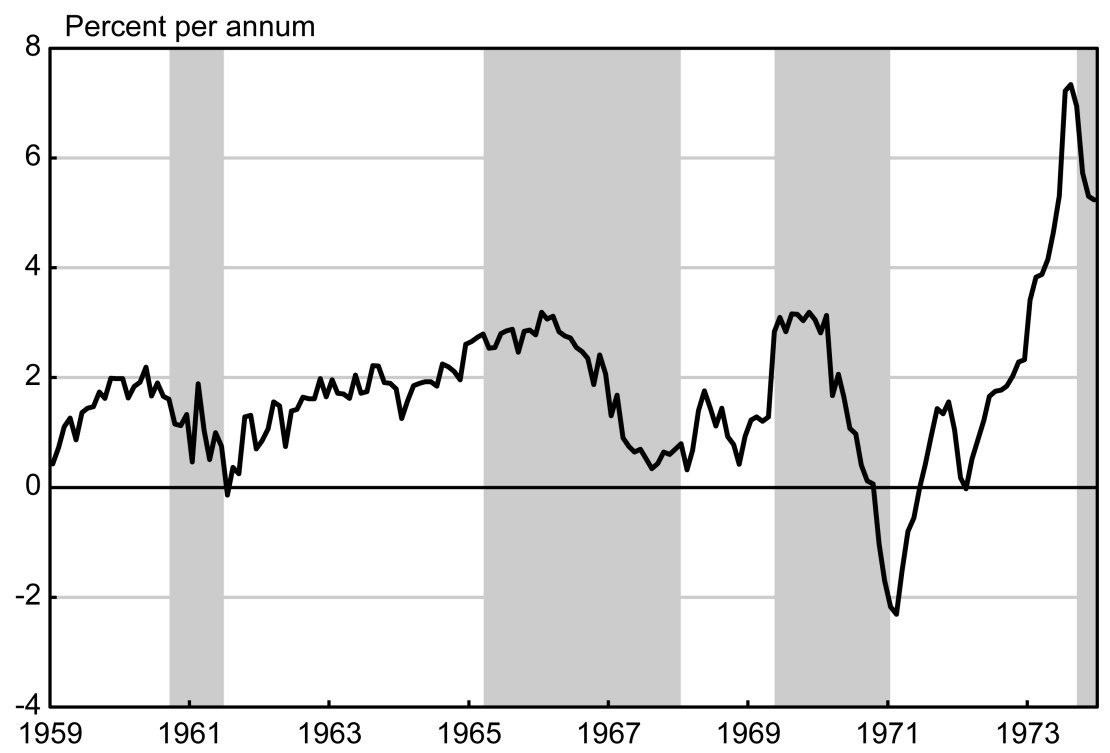

Fig. 4.6 Real federal funds rate, 1959-1973

Notes: The real federal funds rate equals the nominal federal funds rate less the year-to-year percent change in the core CPI. Shaded areas are recessions. Data are from the Federal Reserve System, the Bureau of Labor Statistics, and National Bureau of Economic Research.

fined open-market operations to the very short end of the market for US Treasury securities. Faced with a potential conflict between domestic and balance-of-payments objectives, the Federal Reserve, and later the Kennedy administration, undertook a program intended to promote domestic investment and economic growth through lower long-term interest rates and to discourage short-term financial outflows through higher short-term interest rates (Martin, 1961). ${ }^{18}$ After October 1960, the Federal Reserve began to purchase longer-term securities, while sometimes selling Treasury bills. In addition, the Treasury began issuing more short-term securities, and government trust funds increased the portion of long-term securities in their portfolios (Yeager 1966, 448). In this way, policymakers hoped to twist the yield curve for balance-of-payments purposes while maintaining an overall accommodative policy stance.

Although US policymakers were unwilling to devalue the dollar or reduce US aggregate demand for balance-of-payments purposes, they instituted a number of ad hoc policies designed to improve the country's competitive position, and thereby improve the US balance of payments. As noted, the Eisenhower and Kennedy administrations attributed postwar balanceof-payments deficits in large part to the United States' unusual militaryassistance and economic-development programs. Cutting these programs 
could have had severe political and military consequences in the antagonistic Cold War environment (Gavin 2004). To mitigate their effects on the US balance of payments, the Kennedy administration, often using the threat of troop redeployment, extended the requirements - initially developed under the Eisenhower administration - that tied military and development assistance to purchases of US goods and services (Gavin 2004). The United States also encouraged countries to hasten the repayment of their war debts and to contribute aid to developing nations.

After European currencies became convertible in 1958, US traded goods came under more intense competitive pressures. In response, the Eisenhower and Kennedy administrations lobbied for the removal of discriminatory trade practices, which foreign countries leveled primarily against the United States. The United States had long tolerated these restraints both as means of promoting European and Japanese development and as a way of conserving international reserves. The Kennedy administration also undertook various efforts to promote exports and reduce the duty-free allowance for US tourists. In 1961, the Kennedy administration revised the depreciation schedule, hoping to raise US manufacturing productivity, improve international competitiveness, and promote exports.

While undertaking policy initiatives to improve the United States' international competitive position, policymakers here and abroad attempted to shore up Bretton Woods institutions against short-term capital flight and reserve losses, as well as fostering closer cooperation among the major developed countries. A major initiative was the General Arrangements to Borrow. With short-term financial flows larger, more mobile, and increasingly driven by uncertainties about exchange rates, countries - notably the United States and the United Kingdom - might need to borrow foreign exchange reserves to quell temporary balance-of-payments problems. Under existing quota arrangements, however, the IMF did not have sufficient foreign exchange to supply some needed currencies. In late 1962, the major developed countries instituted a new credit mechanism, the General Arrangements to Borrow, within the IMF. These countries collectively pledged $\$ 6$ billion (equivalent) of their currencies to meet borrowing requests through the IMF (James 1996, 161-65).

To address the strong private demand for gold, President Eisenhower issued an order in January 1961 forbidding US residents from holding gold abroad. More importantly, in 1961 the United States, the United Kingdom, and six continental European countries formed the Gold Pool to keep the London price of gold in line with the official price. (We discuss the Gold Pool in more detail below.)

In 1963, the United States also attempted to trim long-term financial outflows through an Interest Equalization Tax. Initially, the administration levied a 1 percent tax on interest earnings from US-held foreign bonds. In 1965 , the tax was broadened to include US bank loans to foreigners with 
a maturity of one year or more. The tax exempted Canada and developing countries. At this time, the Commerce Department initiated a voluntary program to encourage multinationals to borrow abroad. By 1967, the administration raised the Interest Equalization Tax to 2 percent (see Meltzer 1991, 52). In 1965, the Federal Reserve System also instituted a Voluntary Foreign Credit Restrain Program, designed to reduce US financial institutions' foreign lending and investing.

All of these initiatives attempted to address important aspects of the US balance-of-payments problem. None, however, was capable of immediately offsetting speculative financial flows, which could create contagion problems and increase dollar balances in central banks already holding excess dollars. To address these short-term speculative financial flows and to protect the US gold stock, the Treasury began intervening in 1961.

\subsection{The US Treasury's Decision to Intervene}

In March 1961, the Exchange Stabilization Fund (ESF), with the Federal Reserve Bank of New York acting as its agent, began to intervene in the foreign exchange market for the first time since $1939 .{ }^{19}$ Increased speculative flows prompted the action. The Treasury's operations consisted primarily of forward sales of continental currencies, which were designed to reduce forward premia on these currencies. ${ }^{20}$ Forward premia served as barometers of market confidence in the dollar and provided a strong incentive for financial flows when they exceeded levels consistent with the existing interest-rate differential.

Forward transactions offered the Treasury a number of advantages over spot trades. For one thing, the Treasury, which had only $\$ 336$ million in assets available for intervention in mid-1961, did not need to spend scarce foreign-currency reserves until the contract's maturity date, and then only if the position incurred a loss. ${ }^{21} \mathrm{~A}$ loss, however, was unlikely. Since the ESF sold foreign currencies forward at known premia over the official spot rates, the United States could only incur a substantial loss if the foreign currencies were revalued. ${ }^{22}$ Absent a revaluation, the ESF could buy the foreign currencies needed to repay the forward at the official price. The ESF typically covered its forward sales against a possible revaluation.

The Treasury also undertook some limited spot transactions. These were largely experimental, designed to learn how the market operated and to gauge the impact of such operations on speculative activity. In addition, the Treasury also undertook some unusual gold swaps, which temporarily improved the mix of reserve assets on foreign balance sheets.

\subsubsection{German Mark Interventions}

On 6 and 7 March 1961, Germany and the Netherlands, respectively, revalued their currencies by approximately 5 percent, a smaller amount than 
market participants anticipated. Within days, funds flowed out of British sterling and, to a lesser extent, out of dollars and into continental currencies, especially German marks and Swiss francs. In response, British authorities sold dollars to defend the pound. The speculative attack and Britain's defensive dollar sales inflated dollar holdings at continental central banks and threatened to push their dollar-to-gold reserve ratios above acceptable levels. In addition to adding to the potential demand for US gold reserves, the heavy speculative flows pushed the dollar to a substantial forward discount against many of the European currencies, which tended only to reinforce expectations of further revaluations. Moreover, the limited availability of forward cover induced many market participants with dollar receivables to borrow dollars in New York or in the Eurodollar market and use these funds to buy marks in the spot market (Bulletin, September1962, 1141). This hedging strategy added further to foreign central banks' dollar reserves.

On Monday, 13 March 1961, after consultations with Bundesbank and Federal Reserve officials, the ESF began selling German marks forward in an attempt to reduce the forward premium on marks, which had reached a peak of 4 percent, and hopefully to stabilize exchange-rate fluctuations in both the spot and forward markets. A so-called "parallel" agreement covered the Treasury's risk exposure. Accordingly, the Bundesbank would supply the US Treasury with any marks that it might need to fulfill the forward contracts, and the US Treasury and the Bundesbank would split any profits. The forward sales reached $\$ 63$ million per week by the second week of the operations and continued at a rate of $\$ 30$ million to $\$ 40$ million per week for several weeks thereafter. The operations topped \$320 million in mid-June, but then fell off quickly (US Treasury 1962a, 4).

The Treasury also concluded an arrangement with the German government whereby Germany would immediately prepay $\$ 100$ million of a $\$ 587$ million debt that was due to the United States in April 1961..23 Germany paid in marks. Of this amount, the ESF received $\$ 50$ million equivalent German marks. The ESF used most of it as cover for the forward transactions, but made small intervention sales of German marks in the New York market during June and July to lift the dollar off its floor vis-à-vis the mark. The Treasury coordinated these operations with Bundesbank interventions. The Treasury sold the remaining $\$ 50$ million worth of German marks from the debt prepayment directly to the Bundesbank for dollars on 1 September 1962, thereby reducing Germany's potential claim on US gold reserves (US Treasury 1962a, 5).

When the Soviets built the Berlin wall in August 1961, a substantial amount of funds quickly moved out of Germany. This reversal of financial flows provided a source for funding the US Treasury's forward commitments which, unlike the "parallel agreement," would not cause the Bundesbank to again acquire additional dollar reserves. By mid-December 1961, the Treasury liquidated all of the forward mark commitments, and although the ESF 
incurred small losses on its spot transactions, the overall operation accrued a $\$ 750$ thousand profit (US Treasury 1962a, 5).

The German mark operations convinced US Treasury officials that such cooperative arrangements could provide a "first line of defense" for the dollar. With the US balance-of-payments deficit continuing, further speculative attacks seemed certain. Consequently, the ESF acquired additional German marks from the market when the Berlin crisis temporarily weakened that currency. The ESF made further forward mark sales in late December 1961 when that currency's forward premium again rose above 1 percent against the dollar. By the end of January 1962, the ESF held \$55 million worth of German marks, of which $\$ 50$ million (equivalent) were invested in German Treasury bills. Forward commitments amounted to $\$ 10$ million worth of marks. Of these, "parallel" agreements with the Bundesbank covered \$5.6 million equivalent, and ESF mark holdings covered the remainder (US Treasury 1962a, 6-7). The US Treasury liquidated its forward commitments in German marks by the end of March 1962.

\subsubsection{Swiss Franc Interventions}

In early 1961, dollar inflows increased liquidity in the Swiss banking system and raised the dollar-to-gold ratio at the Swiss National Bank above its legal limit. Instead of converting the excess dollar reserves immediately into gold with the US Treasury, the Swiss National Bank lent dollars to the Bank of England to finance Britain's pound-stabilization program. The Bank of England, however, was arranging financing through the IMF and intended to liquidate Swiss dollar credits (Bulletin September 1962, 1143). The Swiss National Bank (SNB) then sought a mechanism to reduce the excess liquidity in Switzerland stemming from these dollar inflows.

The Swiss National Bank believed that the inflows of funds were temporary and that forward sales of Swiss francs could stem or possibly reverse them by reducing the forward premium on francs. Swiss law, however, prohibited the bank from operating in the forward market. Instead, on 12 July 1961, the ESF began forward sales of Swiss francs. The ESF intended to use \$15 million worth of Swiss francs, which it had acquired earlier from the Swiss National Bank, as cover for the forward operation, but the bank also offered additional Swiss francs against Treasury gold sales.

These initial foreign-exchange operations were small and mainly experimental, but after the Berlin Wall was erected, dollar flows into Switzerland increased sharply. The ESF's forward Swiss franc (SF) sales increased substantially to $\$ 152.5$ million equivalent by the end of November. The Swiss National Bank had earlier provided the US Treasury with a SF 430 million ( $\$ 100$ million) credit line to cover the ESF's forward commitments. To draw on this line, the US Treasury issued $\$ 46$ million of certificates of indebtedness denominated in Swiss francs in October 1961. This was the first time that the Treasury had issued foreign-currency-denominated debt since 
World War I. The Treasury issued the certificates in two lots, at a rate of 1.25 percent with a three-month maturity. The ESF received $\$ 15$ million worth of Swiss francs from the proceeds to meet Swiss franc forward commitments, and the Treasury's general fund kept the remaining \$31 million worth of francs with the Swiss National Bank. The Treasury rolled over one lot of certificates and repaid the other as pressure on the Swiss franc subsided. In addition to these Treasury activities, the Swiss National Bank doubled its dollar working balances to $\$ 200$ million, and thereby reduced the potential gold drain that the US Treasury faced (US Treasury 1962a, 7-8).

The Treasury viewed the Swiss franc operation, as it did the German mark interventions, as highly successful, contending that without it, the United States would have lost somewhere between $\$ 250$ million and $\$ 400$ million in gold reserves (US Treasury 1962a, 8). At the end of January 1962, the Treasury had $\$ 146.5$ million worth of outstanding Swiss franc forward contracts. Profits on the operation amounted to $\$ 450$ thousand.

In February 1962, the Swiss franc began to weaken, requiring the Swiss National Bank to support it with dollar sales. To acquire the necessary dollar balances, the Swiss National Bank sold the Treasury \$73.5 million in gold and \$93.2 million in Swiss francs through May 1962. ${ }^{24}$ Part of the Swiss franc purchases (\$28.1 million equivalent) were on a swap basis. ${ }^{25}$ The Treasury used Swiss franc balances to liquidate forward commitments and the certificates of indebtedness as they matured (Bulletin, September 1962, 1145).

\subsubsection{Netherlands Guilder Intervention}

In September 1961, the US Treasury purchased \$15 million worth of Netherlands guilders, most of which it invested in guilder securities. With these funds providing cover, the Treasury undertook $\$ 4.9$ million (equivalent) in forward sales of guilders through the Netherlands Bank in the Dutch market beginning in January 1962. In February, the Treasury acquired an additional $\$ 15$ million worth of guilders, raising its total to $\$ 30$ million, and expanded its forward operations (US Treasury 1962a, 10). Treasury forward guilder sales in January and February 1962 reached \$20.8 million (equivalent) (Desk Report 1963, B-22). In July 1962, Britain made a large drawing of guilders from the IMF, which it used to buy dollars from the Netherlands Bank. To replenish its dollar reserves, the Netherlands Bank sold \$20 million guilders (equivalent) to the Treasury under a temporary swap agreement (Bulletin, September 1962, 1145). Hence, the Treasury's operations were more than covered, and any excessive inflow of dollars to the Netherlands had ended.

\subsubsection{Italian Lira Interventions}

In 1961, strong dollar inflows pushed the Italian lira to its upper parity limit and kindled rumors of a revaluation. As Italy's dollar-to-gold reserve ratio rose, Italian authorities undertook dollar swaps with domestic com- 
mercial banks that covered the latter's dollar exposure. (We discuss the mechanics of these market swaps below.) The temporary cover that these swaps provided to the Italian commercial banks encouraged them to hold dollar balances instead of converting them to lira at the Bank of Italy. The transactions could be renewed.

In January 1962, the US Treasury took over \$200 million of these swaps, obligating it to deliver lira forward. The Treasury obtained some cover for its commitments through a $\$ 150$ million (equivalent) credit line with Italian authorities. The Treasury acquired an additional $\$ 100$ million of these swap obligations in March. In early 1962, the Treasury also undertook some experimental spot lira transactions (US Treasury 1962a, 10-11).

\subsubsection{Gold Swaps}

In addition to these foreign-currency transactions, the US Treasury undertook a series of three-month gold swaps with the Swiss National Bank and with the Bank of England in 1961. In March, the Treasury sold gold to the SNB for \$25 million worth of Swiss francs under an agreement to reverse the transaction on June 30. At maturity, the Treasury rolled the swap over until 29 July 1961, and also undertook a second \$25 million gold swap, which it reversed on 13 July 1961. The Treasury undertook a $\$ 50$ million (equivalent) gold swap with the Bank of England in April 1961, which matured in equal parts in May and July of that year.

The purpose of these gold swaps is not entirely clear. The Treasury reports that: "These gold transactions were undertaken at US initiative and were designed to smooth out random short-run fluctuations in the Treasury's gold stock." (US Treasury 1962a, 11-12). That may be, but another objective - particularly in the Swiss case - may have been to keep the ratio of dollar reserves to gold below levels that may have required these countries to exchange dollars for US gold.

\subsection{The Federal Reserve's Decision to Intervene}

Both the Treasury and the Federal Reserve System viewed the Treasury's exchange-market interventions in 1961 and early 1962 as unmitigated successes (FOMC Minutes, 12 September 1961, 44). ${ }^{26}$ The Treasury had acted against short-term speculative movements of funds and easily - and profitably - unwound its positions when those speculative pressures reversed.

The ability of the US Treasury to mount another broader dollar defense, however, was severely limited. By late 1962, the ESF had assets equal to approximately $\$ 340$ million, but a large portion of this was committed to stabilization agreements with Latin American countries. This left the ESF with a paltry $\$ 100$ million equivalent in European currencies and only about $\$ 20$ million to $\$ 25$ million available for acquiring additional foreign exchange. ${ }^{27}$ 
The Treasury welcomed and encouraged the Federal Reserve's participation in foreign-exchange-market interventions primarily because it would increase the amount of funds available for such operations. ${ }^{28}$ Since March 1961, the Federal Reserve had sharpened its expertise in the area as the agent for the US Treasury and foreign central banks, but the Treasury already had access to the desk's expertise. What the Treasury needed was the Federal Reserve's seemingly boundless capacity to create reserves and to acquire additional foreign exchange.

On 13 February 1962, the FOMC authorized intervention in the foreignexchange market for the Federal Reserve's own account. By participating with the Treasury, the Federal Reserve hoped to reassert, and possibly extend, its dormant influence in this area. In fact, Chairman Martin may have wanted to bring the entire foreign-exchange operation into the Federal Reserve's domain (FOMC Minutes, 6 March 1962, 72). Foreign-exchange transactions closely paralleled and often interacted with domestic monetarypolicy operations, so much so that many countries viewed intervention as solely a central-bank function. The Federal Reserve Act did not explicitly preclude such activities, and indeed the Federal Reserve had undertaken foreign-exchange operations in the past. One way or another, US foreignexchange operations were going forward, and the Federal Reserve wanted to shape their development.

To be sure, support for intervention within the Federal Reserve at the time was not unanimous. The debates at the FOMC meetings in late 1961 and early 1962 raised issues that would resurface periodically over the next thirty-five years, with the exception that as time went on, dissenters became more concerned about the adverse interactions between intervention and monetary policy, and less concerned about its legality than they were in the early 1960s. In any event, a clear majority of FOMC members have always favored Federal Reserve foreign-exchange operations, provided that they did not make the Federal Reserve in any way subservient to the Treasury, that they did not raise the ire of Congress, and - eventually - that they did not interfere with the domestic objectives of monetary policy.

\subsubsection{Legal Authority for Federal Reserve Interventions}

At their 12 September 1961 meeting, FOMC participants first formally discussed Federal Reserve participation in foreign-exchange operations. Chairman William McChesney Martin, with strong support from the New York Federal Reserve Bank, advocated the central bank's participation. To his mind, there was "no question but that this country was going to be in the business of foreign-exchange operations," and he wanted the Federal Reserve involved either alone, or in conjunction with the US Treasury (FOMC Minutes, 12 September 1961, 44).

Martin contended that the public did not distinguish between the Federal Reserve and the US Treasury in foreign-exchange operations. Moreover, 
congressmen had already asked him informally if the Fed approved of the Treasury's actions, which he interpreted as indicating that the Fed's opinion was important in these matters. To Martin, participating was imperative, even if the Fed's role was very limited. He realized, however, "that the primary direction must come from the Treasury and that everything done by the Federal Reserve must be coordinated with the Treasury." (FOMC Minutes, 12 September1961, 49) Martin did not think this threatened the Federal Reserve's independence. He always contended that the Federal Reserve was independent within the government and was not independent of the government. His distinction implied that the Federal Reserve must coordinate and cooperate with the Treasury as far as possible, and particularly in government actions that did not directly interfere with monetary-policy decisions (see Bremner 2004; Meltzer 2005). Intervention, he believed, was just such an action.

The FOMC's primary concern was Congress, whose opinion about Federal Reserve intervention in the foreign-exchange market had never been unequivocal and firm. In the current climate, if all went smoothly, Congress probably would acquiesce. Congress was aware of the balance-of-payments problem and sympathetic to the policy dilemma that it posed. If the Fed's operations incurred a substantial loss or appeared to interfere with foreign policy, however, the Federal Reserve's relations with Congress could deteriorate. Legislative support for the operations, which Congress never explicitly offered, would have eased the FOMC's concerns. At a minimum, however, the FOMC wanted to be sure that its actions were legal.

The Federal Reserve Act did refer to specific types of foreign-exchange transactions, and at least seven times between 1924 and 1929, the Federal Reserve Bank of New York extended credits to foreign central banks to shore up their reserves in defense of their currencies (Task Force 1990d, Paper no.1, 4-5). In 1925, for example, the Federal Reserve Bank of New York made \$200 million worth of gold available to the Bank of England with the understanding that the Bank of England would place proceeds from any gold sales in a sterling investment account for the Federal Reserve Bank of New York (see chapter 2). In 1933, however, Senator Carter Glass, whom many regarded as the father of the Federal Reserve Act, criticized these transactions, indicating that such "stabilization operations" were inconsistent with the original Act. At that time, as discussed below, the Board of Governors took a position that was not inconsistent with Senator Glass's view. In 1934, Congress passed the Gold Reserve Act, establishing the ESF specifically for the purpose of intervening (see chapter 3). But in passing the Gold Reserve Act, did Congress mean to preclude the Federal Reserve from this arena?

In 1961, Howard Hackley, the Board of Governors' general counsel, provided a legal interpretation of the Federal Reserve Act that the FOMC would now adopt (Hackley 1961; Todd 1992). ${ }^{29}$ The often-cited "Hackley Memo" 
argued that various sections of the Act - when considered together - authorized the Federal Reserve System to hold foreign exchange, to intervene in both the spot and forward markets, and to engage in swap transactions with foreign central banks and with the US Treasury.

Section 14 of the Act seemed to be the key. It allowed the Federal Reserve to purchase and sell both spot and forward "cable transfers" in both domestic and foreign markets. Since cable transfers were the standard means of acquiring foreign exchange in the early part of the century, section 14 seemed to sanction - according to Hackley's interpretation - both types of foreignexchange intervention. More generally, however, section 12A(c) instructed the Federal Reserve System to undertake open-market operations - including transactions in foreign exchange - that accommodate commerce and business by promoting sound credit conditions in the United States. Defending the dollar, cooperating with foreign central banks and the IMF, and promoting trade certainly seemed consistent with this general objective. Section $12 \mathrm{~A}(\mathrm{~b})$ of the Act also specifically required the FOMC's authorization for all such open-market operations.

In addition, section 14(e) allowed the Federal Reserve to hold foreign exchange in the form of open accounts in foreign countries, to appoint correspondents, and to establish agencies. ${ }^{30}$ These are necessary aspects of an intervention operation, particularly if the Federal Reserve hoped to operate through a foreign commercial bank or a central bank in a foreign market. In the 1930s, however, the Board of Governors interpreted this clause narrowly, arguing that the Act allowed the Federal Reserve to open accounts only to facilitate direct intervention transactions, but that the Act did not allow the central bank to hold foreign currency beyond what was immediately necessary for intervention. This interpretation seemed to preclude holding foreign-currency positions acquired outright or through swaps. In 1961, Hackley broadened the interpretation, arguing that the FOMC instead could construe the Act as allowing the Federal Reserve to maintain such accounts provided that it had a reasonable expectation of using them to finance intervention (Hackley 1961, 13). Accordingly, the Federal Reserve now regarded section 14(e) as authorizing it to undertake swaps with other central banks and eventually to amass a huge portfolio of foreign exchange. Hackley's interpretation was a clear change in the Board's attitude and was in agreement with the Federal Reserve Bank of New York's original actions in the 1930s. ${ }^{31}$

More problematic for the Federal Reserve, however, was finding legal authority for purchasing foreign exchange from the ESF on either a permanent or temporary (warehousing) basis. ${ }^{32}$ The Banking Act of 1935 prohibited the Federal Reserve from purchasing government obligations except in the open market. Although Congress had permitted some direct purchases of government securities during World War II, and although the Fed retained some very limited authority to do so after the war, Congress 
clearly did not want the central bank lending resources to the Treasury "in a manner that might be inconsistent with the [Federal Reserve] System's monetary and credit responsibilities" (Hackley 1961, 18). Hackley argued that swap agreements with the Treasury did not violate the open-market provisions of the Banking Act of 1935. In contrast to government securities, foreign currency was not a liability on the US Treasury's balance sheet; therefore, that agency was part of the open market for foreign exchange. Moreover, Hackley asserted, the United States was a "domestic corporation." This was a necessary criterion because the Federal Reserve Act also limited open-market operations to domestic corporations. In Hackley's opinion, the Federal Reserve could lawfully buy and sell foreign exchange from the ESF or the Treasury. ${ }^{33}$ Unlike most of the legal controversies associated with Federal Reserve intervention, the debate about the appropriateness of warehousing would never quite disappear (Broaddus and Goodfriend 1996; Hetzel 1996). Opponents would consistently argue that warehousing constituted a central bank loan to the ESF using foreign exchange as collateral and was, therefore, inappropriate. It contravened principles of central-bank independence and thereby impinged on the credibility of monetary policy. Proponents would eventually argue that warehousing did not constitute a loan, but instead was a straightforward and permissible asset swap between the two agencies.

\subsubsection{Other FOMC Objections}

Aside from the question of the Federal Reserve's legal authority for intervention, four other key issues arose during the FOMC's discussions in late 1961 and early 1962. One was political: Some members of the FOMC feared that even if the Federal Reserve Act did provide legal authority for intervention, Congress might interpret the Federal Reserve's involvement as a budgetary bailout for the Treasury. Congress established the ESF specifically for the purpose of intervening in the foreign-exchange market, and capitalized the fund with an appropriation of $\$ 2.0$ billion. In 1945, Congress used $\$ 1.8$ billion of ESF funds to pay the US contribution to the IMF. Karl Bopp, the president of the Federal Reserve Bank of Philadelphia, argued that these events suggested that Congress intended to limit the amount of funds that the ESF could devote to foreign-exchange operations (FOMC Minutes, 12 September 1961,49-50). If so, then the Federal Reserve's unlimited participation with the ESF might appear as a method of circumventing Congress's budgetary authority. If the ESF wanted more funds for intervention, it should seek a larger Congressional appropriation..$^{34}$ Moreover, the ESF made loans to developing countries and currently had a substantial amount committed to Latin America. These were essentially foreignpolicy actions related to State Department functions. Might Congress view the Federal Reserve's foreign-exchange operations as a backdoor means of financing these foreign-policy operations? Could the Federal Reserve 
become embroiled in a dispute among Congress, the Treasury, and the State Department about foreign policy?

A second FOMC concern focused on the bureaucratic authority for intervention and its implication for Federal Reserve independence. Congress created the ESF and vested the Treasury with primary responsibility for intervention in part because of its dissatisfaction with Fed interventions during the 1920s and 1930s. If the Treasury had primary responsibility for intervention, as Chairman Martin acknowledged, could it direct how the Federal Reserve operated for its own account? The US secretary of the Treasury, the nation's primary financial officer, is responsible to both the president and the Congress of the United States for formulating and implementing all US financial policies, and the Gold Reserve Act of 1934 gave the Treasury primary responsibility for intervention. If, as the FOMC now claimed, the Federal Reserve Act authorized the Federal Reserve to conduct foreign-exchange operations independently, the potential for conflict with the Treasury existed. At a minimum, the Federal Reserve's foreign-exchange operations cannot act in a way contrary to US international financial policies (Task Force 1990c, Paper no. 6). In subsequent testimony before the House Committee on Banking and Currency, Chairman Martin pledged to avoid conflicts with the Treasury in conducting the Federal Reserve's intervention operations, saying "the [Federal Reserve] System will, of course, coordinate its foreign-exchange operations with those of the Treasury Stabilization Fund" (Task Force 1990c, Paper no. 6, 1). Coordination would be on a day-to-day basis.

In addition, the Board staff assumed that the Treasury could not direct the Federal Reserve in operations for the central bank's account (FOMC Minutes, 12 September 1961, 51). Coombs $(1976,72)$ claims that, by agreement, the Treasury could veto Federal Reserve intervention operations with which it did not agree, and that the Federal Reserve could refuse to undertake any operations for its own account with which it did not agree. In an 18 December 1961 letter to Chairman Martin, Treasury Secretary Dillon pledged, "the Treasury on its part would naturally want to avoid impinging on the independence of the Federal Reserve System within the Government." 35 The lines of authority were not clearly defined in the early 1960s, and experience would show that the Treasury's preeminence in the area would indeed create difficulties for the Federal Reserve System, as when the central bank attempted to stop intervening in the 1990s (see chapter 6).

On the surface, the third concern focused on the ability of the Federal Reserve to respond quickly to speculative attacks against the dollar, but underlying this may have been a deeper concern about who would actually run the show within the Fed, and how it would affect the relative authority of the FOMC, the Board of Governors, and the Federal Reserve Bank of New York. Many within the Federal Reserve System thought that a special subcommittee of the FOMC was necessary to directly oversee foreign- 
exchange intervention because an emergency situation could quickly arise when the full committee was unavailable for consultation and reaching immediate decisions. Making a quick response time all the more crucial, the Fed needed to coordinate most operations with foreign central banks, which might be five or even twelve hours ahead. In a memorandum dated 8 February 1962, the Board's general counsel, Howard Hackley, recommended that foreign-exchange operations be put under the supervision of the Board of Governors instead of the FOMC. The board meets almost daily and has foreign-exchange experts on staff. Moreover, while Hackley contended that the law allowing the Federal Reserve to engage in foreignexchange operations was clear, he also argued that giving control to the Board of Governors instead of the FOMC was ". . . more defensible from a legal standpoint." (FOMC Minutes, 13 February 1962, 64). Others, including Governor Robertson who opposed Hackley's interpretation of the Federal Reserve's authority for intervention, and the president of the Federal Reserve Bank of Cleveland, W. D. Fulton, supported Hackley by arguing that the board was more of a "public body" than the FOMC. Apparently, because elected officials appointed governors, but not Federal Reserve Bank presidents, the former had more authority to deal with issues that touched the fringe of foreign policy than the latter. The president of the San Francisco Federal Reserve Bank, Eliot Swan, however, articulated the underlying concern with Hackley's recommendation: "To shift from the Committee to the Board might give support to those who would like to change rather basically the fundamental structure of the [Federal Reserve] System." (FOMC Minutes, 13 February 1962, 68).

While most participants favored maintaining FOMC authority, many thought that a smaller management group was necessary to deal with emergency situations. At issue was the extent of a subcommittee's authority. A subcommittee with broad authority might not confine its activities to administration, but would instead actually make policy (FOMC Minutes, 5 December 1961, 71). Ultimately, the FOMC decided to authorize a committee consisting of the chairman and the vice chairman of the FOMC and the vice chairman of the board to conduct operations when the full committee was unavailable. The subcommittee, however, was to act within FOMC guidelines, which we discuss below. This subcommittee could, however, set maximum amounts of individual currency holdings, establish exchangerate limits, review and approve any agreements between the Federal Reserve Bank of New York and foreign central banks, and take emergency actions when the full FOMC was unavailable.

Chairman Martin also wanted the special manager, who actually undertook intervention operations through the foreign exchange desk at the Federal Reserve Bank of New York, to be an employee of the FOMC and not, as currently was the case, an employee of the Federal Reserve Bank of New York. Not surprisingly, the president of the Federal Reserve Bank of New 
York objected that this move would reduce the bank's authority-specifically the authority of its directors - and wanted to maintain the current setup. The FOMC, however, accepted the chairman's recommendation and the special manager became an employee of the (FOMC Minutes, 17 April 1962, 2-3).

A final issue focused on the exact role of intervention. Policymakers at the Federal Reserve all seemed to agree that the broad objective of intervention was to defend the dollar, thereby reducing gold outflows and bolstering confidence in the dollar's parity. But how extensive should these operations be? At one point, the Federal Reserve Bank of New York suggested undertaking seasonal and cyclical interventions to smooth out anticipated balance-of-payments flows (FOMC Minutes, 5 December 1961, 49). Some FOMC members, however, were concerned that prolonged intervention might actually interfere with balance-of-payments adjustment and actually prolong disequilibrium. Governor Mitchell argued that if a foreign country had a balance-of-payments surplus and wanted to acquire gold, the United States should accommodate that country. The United States, therefore, needed a policy to facilitate an orderly loss of gold. Intervention might prevent a sudden loss of gold, but the danger of prolonged operations was that, absent a fundamental policy change, the demand for gold would continue to grow and eventually worsen confidence in the official gold price. Similarly, Governor King feared that "people would be likely to put too much reliance on these operations to guard the dollar ..." (FOMC Minutes, 12 September 1961, 55). Governor Roberts also feared that if the Fed repeatedly disrupted the private market's pricing process, the willingness of private market participants to make a market in foreign exchange might deteriorate (FOMC Minutes, 5 December 1961, 60). For these reasons, the FOMC favored only temporary interventions that would offset transitional disruptions in the foreign-exchange market and that would not attempt to avoid fundamental market adjustments. As time would tell, however, distinguishing between temporary developments and those of a more fundamental nature was extremely difficult.

\subsubsection{A Cautious Approach}

Most FOMC members favored intervention and were sympathetic to Hackley's interpretation of the Federal Reserve Act. Nevertheless, they wanted to proceed cautiously and to first seek, with the cooperation of the Treasury, legislative clarification from Congress (FOMC Minutes, 5 December 1961, 78-79). In the face of this hesitancy, Chairman Martin, Federal Reserve Bank of New York President Alfred Hayes, and First Vice President of the Federal Reserve Bank of New York Charles Coombs stressed that foreign-exchange markets were currently very sensitive to speculative pressures. They argued for going forward on an emergency basis and seeking congressional approval afterwards. (The Treasury made a similar appeal.) 
The sense of urgency swayed the FOMC. While urgency was the chairman's stated motivation, he also may have hoped to avoid a full-fledged congressional review of the Federal Reserve's role in intervention, especially one that might provide an opportunity for other changes in the Federal Reserve Act. ${ }^{36}$

On 23 January 1962, with two members dissenting, the FOMC approved foreign-exchange operations for the Federal Reserve's account on an experimental basis (FOMC Minutes, 23 January 1962, 41). Governor Mitchell objected, contending that the Federal Reserve first needed Congress's explicit approval. Similarly, Governor Roberts dissented, arguing that the Federal Reserve Act did not clearly authorize these types of stabilization actions, that the FOMC was basing its decision on incidental authority in the Act, and that Congress intended to confer only limited authority for such actions to the Treasury's ESF. ${ }^{37}$

In late February 1962, Chairman Martin reported to the House Committee on Banking and Exchange that the Federal Reserve "had recently decided to reenter the field of foreign-exchange transactions." He reported that the general counsel for the US Treasury and the attorney general of the United States concurred with Hackley's interpretation of the legal basis for the FOMC's decision. In general, the US Congress accepted the Federal Reserve's interpretation of its authority. Representatives Henry Reuss and Wright Patman, however, did not agree. Representative Reuss contended:

Much of the operation that you are doing . . seems to me to duplicate the foreign exchange stabilization operation that the Secretary of the Treasury has very properly undertaken pursuant to the Gold Reserve Act of 1934. To me this is a tremendous power you have taken upon yourself, and I must serve notice on you right now that I consider this an usurpation of the powers of Congress .... You come in here and tell us that you propose to go off on, if I may say so, a frolic of your own, involving unspecified sums without the slightest statutory guidance. (Hetzel 1996).

The Federal Reserve has since reported on its foreign-exchange operations, and Congress has been aware of its activities. In the 1980s, under the Monetary Control Act, Congress amended section 14(B)(1) of the Federal Reserve Act to allow the Federal Reserve to invest foreign currencies acquired through its foreign-exchange operations in short-term foreign government securities. ${ }^{38}$ The FOMC has interpreted this as tacit congressional approval of the Federal Reserve's foreign-exchange operations. Serious concern about the legal authority of the Federal Reserve's intervention activities never again arose within the FOMC. The Federal Reserve, however, continued to worry that Congress might view intervention and related activities as interfering with its appropriations power, and remained concerned about how intervention conducted in conjunction with the Treasury might interfere with its ability to conduct such operations independently. Eventually, as we detail in chapter 6, FOMC participants would worry that the 
operations interfered with the credibility of monetary policy (Broaddus and Goodfriend 1996; Hetzel 1996).

\subsubsection{Rules of Engagement}

On 13 February 1962, the FOMC approved the Authorization Regarding Open Market Transactions in Foreign Currencies, the Guidelines for System Foreign Currency Operations, and the Continuing Authority Directive on System Foreign Currency Operations. ${ }^{39}$ These documents provided the FOMC's instructions to the subcommittee of foreign exchange, the special manager, and the foreign exchange desk of the Federal Reserve Bank of New York for undertaking foreign-exchange operations for the Federal Reserve's account.

The authorization listed the goals of the operations and sanctioned specific types of transactions. As stated in this document, the basic purposes of the operations were: (a) to safeguard the value of the dollar, (b) to improve the efficiency of payments by avoiding disorderly conditions, (c) to promote monetary cooperation among central banks and international organizations, (d) to moderate temporary international payments imbalances that might adversely affect reserves, and (e) to foster growth in international liquidity compatible with the needs of an expanding world economy. In addition to these basic purposes, the document also listed more specific aims for the Federal Reserve's transactions. These were: (a) to protect the US gold reserve from international payments flows stemming from temporary disequilibrating forces or transitional market disturbances, (b) to temper abrupt changes in spot rates and moderate forward premia and discounts judged to be disequilibrating, (c) to supplement exchange arrangements such as those made through the IMF, and (d) to provide a means whereby reciprocal holdings of foreign currencies might contribute to international liquidity needs. The Authorization allowed spot and forward transactions at prevailing rates in both US and foreign markets and allowed transactions with the ESF.

The authorization also provides guidance with respect to communications. Besides keeping the FOMC informed of the operations, the Authorization required close consultation with foreign central banks and also instructed the chairman to keep the secretary of the Treasury fully advised about Federal Reserve foreign-currency operations. The chairman was to consult with the secretary on all matters that related to Treasury responsibilities, and the Federal Reserve staff was to transmit all pertinent information about Federal Reserve foreign-currency operations to the US Treasury. A daily conference call would take place among representatives of the Federal Reserve Board, the Treasury, and the Federal Reserve Bank of New York (US Treasury 1962b, 5-6). At this call, participants would discuss current market conditions and any planned operations. At the end of the day, the Federal Reserve Bank of New York would provide to all principals a sum- 
mary of the day's operations. The Authorization also instructed the chairman to report periodically to the National Advisory Council on International Monetary and Financial Problems. The FOMC also understood that the Federal Reserve and the Treasury would consult before "either entered into any agreements with foreign central banks or governments regarding possible foreign-currency operations." (FOMC Minutes, 13 February 1962, 93). The Authorization established the aforementioned subcommittee for foreign-exchange operations to instruct the special manager when the full FOMC was unavailable.

The guidelines are more explicit with respect to current operations. On 13 February 1962, they limited the holdings of foreign currency to an amount that would allow the foreign exchange desk to "exert a market influence," and to cover outstanding forward commitments. It also instructed the Federal Reserve Bank of New York on operating procedures. The desk was to transact at prevailing exchange rates and was not to attempt to establish rates that were inconsistent with underlying market forces. Absent explicit authorization to the contrary, the Federal Reserve Bank of New York was to purchase foreign currencies at or below their par values and was to lower the rate that it paid for any foreign currency as the amount that the bank held approached the limits that the FOMC set. The Federal Reserve Bank of New York was to follow a similar technique for sales of foreign exchange. The document also required that operations be coordinated in the sense of not acting at cross purposes with another central bank.

The guidelines indicated that spot intervention was appropriate "whenever exchange-market instability threatens to produce disorderly conditions" and listed some conditions (e.g., political tensions, wide interest-rate differentials) that might signal such developments (FOMC Minutes, 13 February 1962, 88). Forward operations were appropriate when forward premia or discounts were inconsistent with interest-rate differentials or when such forward operations "encourage[ed] the retention or accumulation of dollar holdings abroad." (FOMC Minutes, 13 February 1962, 89) This latter condition allowed for swap transactions. The Guidelines also allowed the FOMC to take over outstanding forward contracts that the ESF originated. The Federal Reserve also agreed to purchase foreign currencies that the Treasury acquired under existing credit arrangements with foreign central banks and governments and to do likewise - after consultation - in the future, and to buy foreign currencies that the Treasury acquired from the IMF (FOMC Minutes, 13 February 1962, 94). Moreover, the Federal Reserve agreed "to purchase currencies . . f from the Treasury either outright or under mutually satisfactory resale agreement [warehousing], in the event that exchangemarket developments obliged the Fund to exhaust available resources." (FOMC Minutes, 13 February 1962, 94).

The initial continuing authority sanctioned transactions in British pounds, French francs, German marks, Italian lira, Netherlands guilders, 
and Swiss francs, with total holdings not to exceed $\$ 500$ million. This limitation and listing of currencies would frequently change to accommodate broader operations.

\subsubsection{Acquiring an Initial Position}

With a balance-of-payments deficit and the dollar often trading at the lower end of parity bands, the Fed needed foreign exchange to mount any dollar defense, but any purchase of foreign exchange would supply more dollars to the market, put additional downward pressure on the dollar, and increase the potential drain of US gold reserves (US Treasury 1962b). The Fed looked to acquire a small amount of foreign exchange from the market or from foreign central banks whenever a fortuitous opportunity presented itself, and some occasions arose in early 1962. In addition, the Treasury sold outright to the Federal Reserve System $\$ 32$ million worth of German marks in February and March, and \$0.5 million worth (each) of Swiss francs, Netherlands guilder, and Italian lira (Desk Report 1963). The Treasury also agreed to sell to the Federal Reserve System, either outright or through repurchase agreements, currencies held by the ESF, if the ESF exhausted its available dollar funds for foreign-exchange operations. These currencies permitted the Federal Reserve to open accounts with the central banks of Germany, Switzerland, the Netherlands, and Italy. The Federal Reserve already had British sterling and French francs in accounts with the Bank of England and with the Bank of France (FOMC 1962, 1). ${ }^{40}$ Holding large balances in a wide range of foreign currency, however, increased the Federal Reserve's risks of a valuation loss (Coombs 1976, 74).

The Federal Reserve also established a series of reciprocal currency arrangements - the swap network - with major central banks. The swap network, which provided the Federal Reserve - and foreign central banks an off-market mechanism for financing foreign exchange operations, was the United States' first line of defense during Bretton Woods.

\subsection{Mechanisms of Exchange-Rate Policy}

During the Bretton Woods era, the Federal Reserve System and the US Treasury intervened using various mechanisms, which we review in this section. Although the Federal Reserve and the Treasury often worked in tandem adopting similar techniques at the same time, a clear division of responsibility existed between these agencies. The Federal Reserve focused on short-term operations, typically financed through drawings on its swap lines. Ideally, the Federal Reserve would soon reverse these transactions, so exchange-rate exposure and exchange loss generally were not big concerns. The US Treasury, as noted, often engaged in similar short-term operations, but because of its clearer authority for intervention, the Treasury also undertook operations of a longer-term nature. Most importantly, as per a 
23 July 1962 understanding between Chairman Martin and Treasury Secretary Fowler, the Treasury stood ready to backstop central bank's operations if market conditions prevented the Federal Reserve from reversing a swap drawing on time. To do so, the Treasury could either issue foreign-currencydenominated securities - short-term certificates of indebtedness or longterm Roosa bonds - or draw foreign exchange from the International Monetary Fund, or sell gold for foreign exchange and then sell the proceeds to the Federal Reserve. In addition, the US government sometimes cajoled foreign governments into holding larger dollar portfolios.

\subsubsection{Reciprocal Currency Agreements-Swap Lines}

From 1962 until the closing of the US gold window in August 1971, the reciprocal currency arrangements, or swap lines, were the Federal Reserve System's key mechanism for defending the US gold stock, and they also became an important means for temporarily providing dollar liquidity to foreign central banks. ${ }^{41}$ Swaps involve the simultaneous spot purchase and forward sale of one currency against another. ${ }^{42}$ The transactions provided both the Federal Reserve and participating foreign central banks with short-term credits for dealing with temporary and unwanted changes in official dollar reserves. Temporary - the key operative word-implied reserve changes that monetary authorities expected to quickly turn around. Countries were not to use swap drawings to avoid fundamental balanceof-payments adjustments, although distinguishing between temporary and fundamental problems proved a formidable, often impossible, task.

Ideally, "the very existence of the arrangements, even when they [were] not used, [was] thought to have a stabilizing effect." (Holland 1967, 4-5; Solomon 1971) This passive influence occurred through two channels. For one thing, the swap lines signaled central-bank cooperation and thereby mitigated uncertainty that otherwise might foster speculative activity. In addition, the existence of the swap lines raised the potential costs of speculation. Central banks often increased the swap lines during tumultuous periods, but as figure 4.7 shows, they never drew on the full capacity of the lines. Swaps offered a threat to speculators.

The swap mechanism functioned as follows: The Federal Reserve System would sell US dollars spot to a foreign central bank for its own currency and immediately sell that foreign currency back to that same foreign central bank for delivery at a set future date (Task Force 1990f, Paper no. 9). ${ }^{43}$ The repayment would terminate the swap drawing, but not the line. Central banks, in almost all cases, annually negotiated - on a bilateral basis - overall credit limits for the swap lines. Drawings initially had a term of three months, but could be renewed once if the parties agreed. (The swap line with the National Bank of Belgium had an initial six-month term.) Ideally, banks were not to seek a second renewal, and "every effort was made to prevent a facility from being in continuous use for as long as a year." (Task Force 1990f, Paper 


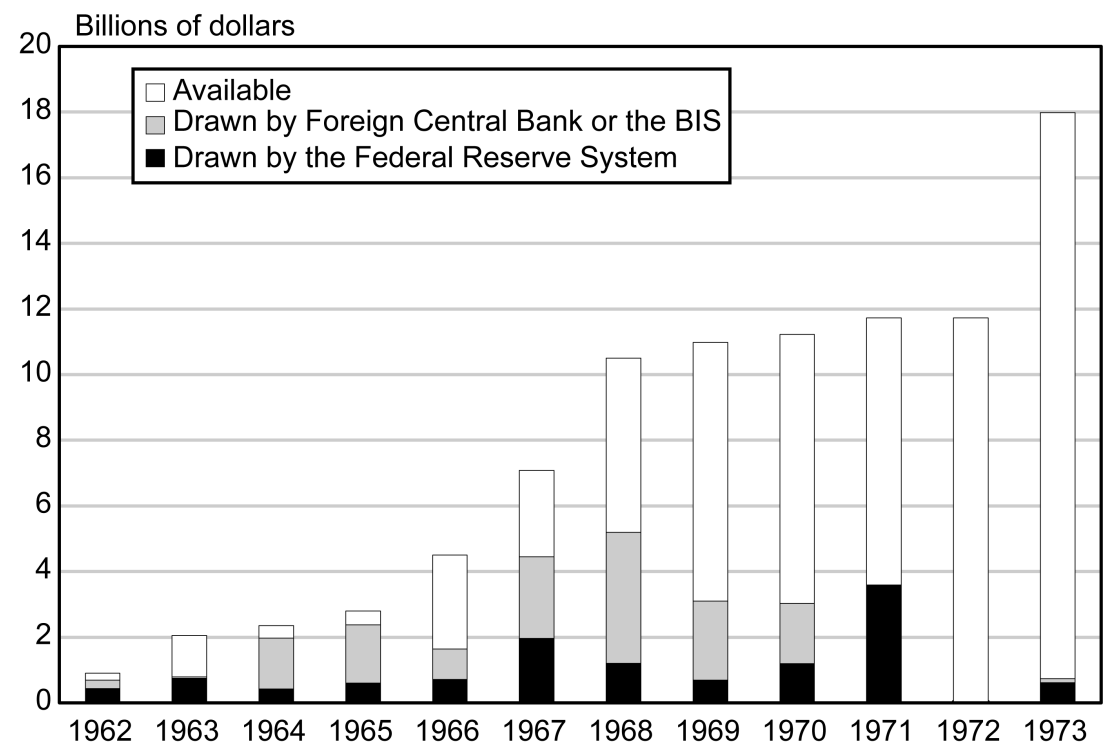

Fig. 4.7 Federal Reserve swap lines, 1962-1973

Note: Data are from the Federal Reserve System.

no. 9, 3) The Federal Reserve's lines - unlike the Treasury's - were reciprocal, meaning that either party could initiate a drawing.

Because swaps provided only temporary credits under a pegged-rate system, they were unlikely to result in large losses. Quite the contrary, when all things worked according to design, the central bank that drew on the swap line tended to profit from the operation, because it sold foreign exchange against its own currency when its own currency was trading below par and bought foreign exchange to repay the line when its currency had appreciated (Bodner 1970, 1). Because swaps were relatively safe, central banks did not apply conditions such as the adoption of macroeconomic policies or the application for funds from the IMF to their use. ${ }^{44}$ This made them readily available. Only a two-day notice was necessary for a drawing.

Participants undertook the spot leg of the swap at prevailing market exchange rates. During the Bretton Woods era, the forward leg of any transaction was undertaken at the same exchange rate. Hence, the swap itself incurred no exchange-rate risk. The central bank that drew on a swap line and used the foreign exchange for intervention, however, was exposed to exchange-rate risk, since it did not know the precise price of obtaining foreign exchange to retire the swap drawing. To protect the debtor central bank should the creditor central bank revalue its currency during the term of a swap drawing, the lines included "revaluation clauses" allowing the borrowing central bank to obtain from the creditor central bank sufficient 
foreign exchange to repay its obligation at a market-based exchange rate prevailing prior to the revaluation. As we will see, revaluation clauses proved problematic in the face of a dollar devaluation, and they did not apply to the adoption of a float. The Federal Reserve exercised a revaluation clause only once, in May 1971, against the Netherlands Bank.

In all cases, the central bank initiating the swap also paid interest on its borrowings. The creditor central bank invested the foreign currency that it acquired from the debtor central bank for the term of the swap in a time deposit or in some other interest-earning asset. (The debtor would do likewise with any unused balances.) During the Bretton Woods era, both the interest rate that the creditor country received and the interest rate that the borrower received were equal to the interest rate on three-month US Treasury bills. ${ }^{45}$ If necessary, interest effectively could be paid by adjusting the spot and forward exchange rates on the swap.

In March 1962, the Federal Reserve established its first swap line with the Bank of France. ${ }^{46}$ The Federal Reserve drew on this line, renewed it once, and repaid the line in August 1962. The Federal Reserve did not intervene with the funds so acquired; the operation was a test of the mechanisms. The French franc swap line then existed on standby status. In May 1962, the Federal Reserve established a second line with the Bank of England. Again, the Federal Reserve drew on the line to test the "telex, investment, and other technical procedures" involved with the operations (Coombs 1976, 79). By the end of that year, the Federal Reserve had established lines with eight key European central banks and the Bank of Canada that provided up to $\$ 900$ million equivalent in foreign exchange. ${ }^{47} \mathrm{~A}$ broad set of lines was necessary because many foreign central banks acquired excess dollars, a potential claim on US gold. The network continued to grow, and it evolved from a small, very short-term credit facility in 1962 to a large, intermediate-term facility by the closing of the US gold window in 1971 (see figure 4.7). By then, the swap network totaled $\$ 11.2$ billion equivalent and involved fourteen central banks, having picked up the central banks of Denmark, Japan, Mexico, Norway, and Sweden over the intervening years. ${ }^{48}$ In addition, the term of a typical swap drawing increased from the original three months to six months. The expansion of the swap lines was a natural consequence of both the mounting threat to the US gold stock and the growing volume of international transactions, but the increasing length of swap drawings and the frequent tendency to renew them suggested that the underlying disequilibrium was of a more fundamental than temporary nature.

\subsubsection{Providing Cover- the Swiss Franc Example}

Between 1962 and the closing of the US gold window in 1971, the Federal Reserve borrowed $\$ 11.5$ billion worth of foreign exchange through its swap lines (see figure 4.8). ${ }^{49}$ Usually — but not exclusively — the Federal Reserve used these funds to provide foreign central banks with cover for temporary, 


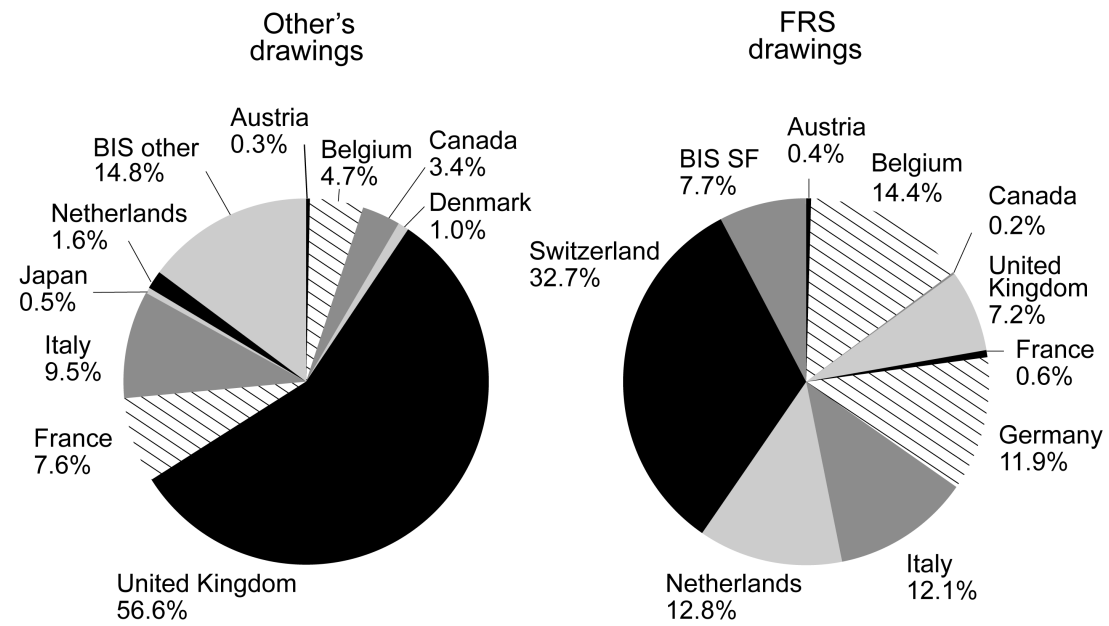

Total: $\$ 15.3$ billion

Total: $\$ 11.5$ billion

Fig. 4.8 Composition of drawings on the Federal Reserve swap lines, 1962-1971 Note: Data are from the Federal Reserve System.

undesirable surges in their dollar balances, and thereby to discourage these central banks from quickly converting unwanted dollars into gold with the US Treasury. To accomplish this, the Federal Reserve used the foreign exchange that it obtained in a swap drawing to acquire dollars from the same foreign central bank. This set of transactions - the swap drawing and the acquisition of dollars - left the foreign central bank holding exactly the same amount of dollars as it did before the swap took place. The dollars that the foreign central bank now held, however, were free of foreign exchange risk since the Federal Reserve contracted to buy them back via the forward leg of the swap at a set exchange rate.

By far, the Federal Reserve undertook the largest cover operations with the Swiss National Bank (SNB), and these serve as an example of the pitfalls and benefits of these types of operations. Between 1962 and 1971, the Federal Reserve drew nearly $\$ 4.7$ billion equivalent Swiss francs from swap lines with the Swiss National Bank and the Bank for International Settlements (BIS). ${ }^{50}$ The Swiss franc drawings amounted to over 40 percent of all Federal Reserve drawings during the Bretton Woods era.

At the time, the Swiss franc functioned as a key safe-haven currency, attracting funds that flowed out of British pounds, US dollars, and other overvalued currencies. As noted, these flows went through dollars and left the SNB holding unwanted dollar exposures. Absent a mechanism to provide cover, the SNB undoubtedly would have shed these dollars for gold.

In mid-1962, for example, persistent speculative inflows lifted the Swiss 
franc to the upper limits of its parity range against the dollar. Forced to intervene, the SNB acquired US dollars in excess of its informal limits. Special manager Charles Coombs feared that "Unless we can . . . mop up a sizable proportion of the dollars recently taken in by the Swiss National Bank we face the prospect of very large gold losses which might easily trigger off an avalanche of demand from other quarters." (FOMC Minutes, 10 July 1962, 52-53, emphasis added). In response, the Federal Reserve opened the two aforementioned Swiss franc swap lines, each for $\$ 100$ million, and immediately drew $\$ 50$ million worth of Swiss francs from each line to provide cover to the SNB.

Because they matured in three months, shortly after making the drawings, the Federal Reserve looked for opportunities to acquire Swiss francs to repay the swaps. A window of opportunity presented itself from late summer until the Cuban missile crisis in mid-October 1962, during which time pressures on the Swiss franc subsided. The Federal Reserve bought Swiss francs in the market, but could not acquire enough Swiss francs to pay off all of its outstanding obligations, because, despite the relative calm, the Swiss franc often traded above its par value, and the FOMC prohibited the desk from buying foreign exchange at exchange rates above par. ${ }^{51}$ The Federal Reserve's second option was to buy the necessary Swiss francs from the SNB, but with dollars still trickling into Switzerland, the SNB was reluctant to acquire still more dollars through such a sale. On 2 October 1962, Coombs asked the FOMC to renew for an additional three months all outstanding Swiss franc swap lines with the SNB and the BIS. This seemingly innocuous rollover, however, pointed to the fundamental problem with the swap network. How much time was necessary to distinguish between a temporary and a fundamental disequilibrium, or when should the US. Treasury settle in gold?

In early 1963, a second window of opportunity opened, and the Federal Reserve managed to liquidate $\$ 80$ million worth of its $\$ 105$ million equivalent Swiss franc obligation by buying Swiss francs in the market, from the US Treasury and from the SNB. The Federal Reserve, however, also took a new tack. On 28 May 1963, the FOMC authorized the desk to swap \$13 million equivalent British pounds from its portfolio for Swiss francs with the BIS. Despite the limits on swap maturities and rollovers, the Federal Reserve did not repay this drawing until the end of 1964 - well over one year. Using this so-called third-party swap to extinguish a bilateral swap, however, does not discharge the central bank's short position, but merely changes the currency composition of that position and extends the maturity of its liability. It also reduces the liquidity of the Federal Reserve's overall long position in foreign exchange (Board of Governors, 21 March 1966, 35).

By mid-1963, rising Swiss money market rates attracted renewed dollar inflows, and following the assassination of President Kennedy in November 1963, the Swiss francs again reached the top of the parity band. The situation led to new rounds of intervention, with the Federal Reserve providing 
additional cover to the SNB. By early 1964, the Federal Reserve owed the SNB \$70 million worth of Swiss francs and owed the BIS \$145 million worth of Swiss francs.

Once again the Swiss franc traded above par, and the Federal Reserve could not acquire sufficient Swiss francs to repay its outstanding commitments. Consequently, in May 1964, the parties involved agreed on a series of measures to reduce the Federal Reserve's outstanding debt. The Treasury issued $\$ 70$ million worth of Swiss-franc-denominated Roosa bonds to the BIS and sold the proceeds outright to the Federal Reserve, which repaid an equivalent amount of Swiss-franc debt to the BIS. Through this transaction, the BIS substituted long-term dollar-denominated debt for shortterm dollar-denominated debt on its books. In June 1964, the Bank of Italy swapped \$100 million equivalent Italian lire for Swiss francs with SNB and sold the Swiss francs thus acquired to the Federal Reserve System for dollars to bolster Italian reserves. The central bank retired its outstanding commitments to the SNB, but to do so, the SNB had substituted lira-denominated assets for dollar-denominated assets on its books. In late June, the Federal Reserve paid down its Swiss franc debt to the BIS with francs that it obtained via the US Treasury from gold sales to the SNB.

In late 1964 and early 1965, funds again poured into Switzerland, and the Federal Reserve again drew on its Swiss franc swap lines to offer cover. This time, however, the situation quickly reversed. By spring, Swiss commercial banks began placing funds abroad, and the SNB eventually began selling dollars in support of the Swiss franc for the first time since 1962. Under these circumstances the Federal Reserve was able to acquire Swiss francs in the market, from the SNB and through transactions with other central banks to cover its outstanding obligations by midyear. The Federal Reserve's swap line reverted to standby status although the Federal Reserve still had a Swiss franc obligation with the BIS stemming from a German mark cross swap. In 1966, funds again moved out of Switzerland and into the Eurodollar market, and the Swiss National Bank sold dollars to moderate the franc's decline. To replenish its dollar reserves, the SNB sold Swiss francs to the Treasury and the Federal Reserve. In addition, the SNB sold gold to the Treasury.

Operations to provide cover persisted until the closing of the gold window in August 1971. The Federal Reserve frequently encountered problems similar to those experienced with Swiss franc swaps and resorted to similar fixes. All in all, however, the Federal Reserve's swap lines often succeeded in preventing countries from converting temporary inflows of unwanted dollar reserves into Treasury gold. Between 1962 and the end of 1969, Federal Reserve swap drawings totaled nearly $\$ 7$ billion equivalent..$^{52}$ In general, reversals in flows into foreign countries - as described in the Swiss franc example - enabled the Federal Reserve to repay approximately three-fourths of its swap drawings. Repayments out of gold sales amounted to only \$186 
million. The issuance of US Treasury bonds denominated in foreign currencies and US drawings on the IMF financed the remainder. From the end of 1969 through 12 August 1971, the Federal Reserve drew $\$ 4.5$ billion in foreign currencies through the swap lines. Suggestive of the deteriorating position of the dollar, the Treasury had to finance most of the repayments through the sale of reserve assets.

\subsubsection{Temporary Liquidity}

The Federal Reserve's swap lines were reciprocal, meaning that foreign central banks could initiate drawings when they needed a temporary increase in their dollar liquidity. During the Bretton Woods era, this became an important function of the swap lines. Between 1962 and 1971, foreign central banks initiated drawings of $\$ 15.3$ billion dollars (figure 4.8). The Bank of England undertook over one-half of these drawings in defense of the pound's exchange rate, as we discuss below.

Canada was the first to draw on the new swap lines for liquidity purposes. In March 1962, the Canadian dollar, which had floated since September 1950, came under strong downward pressure as monetary and fiscal policies eased and speculative pressures on the Canadian dollar intensified. ${ }^{53}$ In an effort to restore stability and confidence to the market, Canada established a par value for the dollar at US\$ 0.9250 on 2 May 1962. Intense speculative pressure followed because the market anticipated a rate closer to US\$0.90 and believed the new peg would not hold.

On 26 June 1962, the Federal Reserve System opened with the Bank of Canada a $\$ 250$ million swap line-five times the size of any other line then in existence. In addition to the swap line, Canada received credits from the IMF ( $\$ 300$ million), the Bank of England (\$100 million), and the US ExportImport Bank ( $\$ 400$ million). The Bank of Canada immediately drew down the entire amount of the swap line and used the proceeds to defend the newly established parity. The drawing had an initial maturity of 26 September 1962, but the Bank of Canada renewed it for another three months. Financial flows into Canada resumed by the fall of 1962, enabling Canada to repay the swap by year's end.

Despite the success of the Canadian operation, the Federal Reserve feared that the existence of temporary dollar liquidity through the swap lines might actually discourage foreign central banks from holding additional dollar balances, and indeed this seems to have happened. "Of the eleven countries with which the [Federal Reserve] System has concluded swap arrangements, five (Belgium, France, Netherlands, Switzerland, the United Kingdom) only hold necessary working balances in official dollar balances. Among the others, Germany has cut its dollar holdings in half since the end of 1961, and Austria and Canada have kept their dollar holdings at about their 1961 levels. Only Italy, Japan and Sweden have substantially increased their 
official dollar holdings, and only in the case of Italy has this behavior been clearly attributable to the cover given by inter-official transactions." (Board of Governors, 21 March 1966, 31).

\subsubsection{Other Uses}

The Federal Reserve established a second swap line - in addition to its Swiss franc line- - with the BIS in 1965 to provide that bank with a means of acquiring temporary cash for routine transactions and to provide the Federal Reserve with access to additional foreign currencies. Previously if the BIS need cash, it borrowed against gold that it held at the Federal Reserve Bank of New York.

The Federal Reserve eventually began using this BIS swap line to supply funds to the Eurodollar market during times of strain when high Eurodollar rates would draw funds from the United States (Task Force 1990f, Paper no. 9, 12). The Federal Reserve asked the BIS to draw dollars on its non-Swiss franc swap line and to place the funds in the Eurodollar market. ${ }^{54}$ Previously, the Federal Reserve had asked foreign central banks to do so during times of stress, particularly if the stress threatened to affect the foreign-exchange market, and often offered forward cover to facilitate such operations (MacLaury 1969, 10). These placements became fairly routine, but were often insufficient to the task.

Besides intervening in the Eurodollar market, the BIS drew on the line to provide support for the British pound (MacLaury 1969, 12). Almost all such drawings were repaid within a month, either at or prior to, their maturity date. The only exception occurred in a November 1967 drawing that extended for two months. After the United Kingdom, the BIS drew the largest amounts on the US swap lines, accounting for nearly 15 percent of the drawing between 1962 and 1971.

\subsubsection{Sterilization}

Swap drawings have the potential to affect US bank reserves, depending on what the Federal Reserve does with the foreign currency that it receivesthe desk can buy dollars or hold and invest the funds - and on what the foreign central bank does with the corresponding dollars - it can buy foreign exchange, buy Treasury securities, hold a deposit at the Federal Reserve, or place the funds in the Eurodollar market. In any of these cases, the Federal Reserve could easily sterilize the transaction to any extent necessary. The manager of the domestic desk, in determining the appropriate amount of open-market operations to undertake on a particular day, regularly took account of changes in foreign accounts at the Federal Reserve, changes in Treasury cash balances, changes in float, and changes in currency in circulation. Many of these can change following a swap drawing. In addition, close communications between central banks and with the Bank for International Settlements generally kept the desk appraised of any prospective 
swap drawing and aware of the anticipated use of the funds. At times the Federal Reserve has requested a particular use of the dollars from a swap drawing that it initiated. The desk's ability to sterilize was further enhanced because the value date of a swap drawing occurs two business days after the transaction date. MacLaury $(1969,9)$ summarized the Federal Reserve's review of sterilization:

In practice, the size of foreign drawings, large as they have been at times, has not been more than the domestic trading desk could offset - for the most part immediately - through open market operations. So long as the availability of the swap line is unconditional, the reserve consequences of foreign drawings are one of the operating factors that the Manager for domestic operations has to take into account in determining the size or direction of his own operations in any given day or week. They thus fall in the category of changes in Treasury cash balances, changes in float, and changes in currency in circulation. (MacLaury 1969, 9).

The effect of swap drawing of desk operations was no different than the normal problems that the desk faces because the dollar is a reserve and vehicle currency.

\subsubsection{Spot Market Operations}

Spot market interventions played a comparatively minor part in US exchange-market operations between 1962 and 1971. The Federal Reserve and the US Treasury generally did not regard spot market intervention as an effective means of preventing a persistent run on the US monetary gold stock - the key US objective. ${ }^{55}$ At best, spot market interventions might contribute tangentially to this objective. In addition, the Board feared that spot market interventions, if they successfully alter one exchange rate, might create a "broad range" of arbitrage incentives through other currencies, requiring simultaneous interventions across a wide swath of currencies (Board of Governors, 21 March 1966, 16). Consequently, the onus of spot market intervention stayed with foreign monetary authorities who established par values for their currencies in terms of the dollar.

Although spot market transactions did not directly forestall a drain on the US monetary gold stock, US authorities occasionally intervened to calm developments that, if left unchecked, might grow to threaten the existing parity structure. The most notable occasion occurred immediately following President Kennedy's assassination on 22 November $1963 .{ }^{56}$ At this time, trading in the New York market essentially stopped. To prevent panic selling, which seemed to afflict the stock market at the time, the foreign exchange desk placed large orders to sell all major currencies at the exchange rates that existed just prior to the assassination. By the close of business, the desk had sold \$23.5 million equivalent German marks, British pounds, Netherlands guilders, Canadian dollars, and Swiss francs. On that same day, the 
Bank of Canada bought $\$ 24.5$ million to support the US dollar against its Canadian counterpart. The European markets were closed at the time of the assassination. When they reopened, foreign central banks intervened in their spot markets, but by then, markets had settled down.

Similarly, news of the Cuban missile crisis on 22 October 1962 generated large financial flows out of dollars and into continental currencies, especially Swiss francs. If left unchecked, the desk feared, these financial flows might raise doubts about the structure of the exchange rates. Moreover, by placing unwanted dollars in the Swiss National Bank, they contributed to a potential drain on the US gold stock. The Federal Reserve System responded by selling $\$ 8$ million worth of francs into the Swiss spot market through the Swiss National Bank and \$2.3 million equivalent francs into the New York spot market. The Swiss National Bank also acquired \$50 million through its own intervention. (The Federal Reserve then drew \$20 million equivalent Swiss francs through its swap line with the BIS on 31 October 1962 and bought dollars from the Swiss National Bank.) The Federal Reserve also sold $\$ 700$ thousand equivalent Dutch guilders in the New York spot market at the onset of the Cuban missile crisis.

Interventions during international crises were relatively isolated events. Much more common between 1962 and 1971 were US efforts to moderate declines (lean against the wind) in the German mark-US dollar rate through spot transactions. These operations ultimately sought to reduce expectations of a mark revaluation (see below). The Federal Reserve often sold German marks, which it acquired through the swap drawings in the German market, and after that market closed, in the New York market. ${ }^{57}$

On at least one occasion, the Federal Reserve intervened to reinforce an exchange-rate movement. In September 1965, the Federal Reserve System, in conjunction with other foreign central banks, bought British pounds in the spot markets. At the time, speculators held short positions, which they needed to cover, and were consequently buying British pounds. By also buying sterling at successively higher quotes, the central bank hoped to reinforce the demand for sterling - to lean with the wind. Sterling began to appreciate.

To guard against the possibility that persistent spot market transactions might create market distortions, the FOMC's Guidelines to the Special Manager allow him to "purchase and sell authorized currencies at prevailing market rates without trying to establish rates that appear to be out of line with underlying market forces." Some opponents of intervention, for example, worried that interventions could actually encourage further speculative financial flows by signaling official concern about the seriousness of a situation.

\subsubsection{Forward Market Operations}

Beginning in 1964, the Federal Reserve undertook forward-market transactions - often in concert with the US Treasury — with both the private 
sector and foreign central banks. The transactions sought to provide counterparties with cover against dollar position and to influence forward exchange rates (Board of Governors, 21 March 1966, 24-29). As noted, the US Treasury had found forward transactions particularly successful in 1961.

The Federal Reserve System frequently sold foreign exchange forward as a means of providing forward cover to private individuals currently holding, or expecting soon to acquire, dollar balances. Often this was undertaken in conjunction with a foreign central bank's spot market sale of dollars. Sometimes it was undertaken as part of a Federal Reserve "market swap," in which the central bank bought foreign exchange spot and sold it forward into the market. Lacking the cover that such Federal Reserve forward sales generally provided, these private individuals probably would have sold their dollar balances to their respective central banks, which in turn might have converted the additional dollar balances to gold. An example of this type of forward transaction occurred in late 1964 and early 1965, when tight monetary conditions attracted funds out of British pounds, through dollars, and into Netherlands guilders. In December 1964 and January 1965, the Federal Reserve and the Exchange Stabilization Fund, in cooperation with the Netherlands Bank, sold \$98.6 million and \$95.4 million equivalent guilders, respectively, in the forward market. ${ }^{58}$ This gave private individuals holding dollars the ability to sell them forward at a known exchange rate.

According to a Federal Reserve analysis, these transactions were effective in holding down the accumulation of dollars at the Netherlands Bank over the eight- to nine-month period that they were in force (Board of Governors, 21 March 1966, 25). Nevertheless, the transactions left the Federal Reserve and the Treasury carrying currency exposures for five and eight months, respectively, and raised questions about what constituted a temporary intervention. As a rule, normal Federal Reserve swap drawings with central banks at the time expired within three months and parties could not roll them over for more than a year.

In a somewhat similar type of forward transaction, US monetary authorities sometimes offered to "take over" forward commitments from foreign monetary authorities. In the fall of 1965, for example, Italian authorities were experiencing substantial dollar inflows that were creating excess liquidity in their banking system. In an effort to reduce liquidity and to shift these inflows forward, the Italian Exchange Offices (IEO) undertook swaps with Italian commercial banks. In these transactions, the IEO would sell dollars spot to commercial banks for lira, which the IEO would then use to buy dollars spot, and repurchase the lira forward. These so-called market swaps provided commercial banks with cover for their dollar exposures at a favorable rate. Moreover the IEO could roll over the market swaps if necessary until the conditions that created the inflow subsided.

Despite this maneuver, the IEO was under pressure to convert the dollars, which ultimately presented them with an exchange-risk exposure, into 
gold. In early 1965, the Treasury, and later the Federal Reserve, began to take technical responsibilities for the IEO swaps. ${ }^{59}$ The Treasury started acquiring commitments in March 1965 and these rose to $\$ 1.0$ billion equivalent by November 1965. The Federal Reserve-under a new authorization-acquired $\$ 500$ million in forward commitments with Italian banks in November 1965. The IEO agreed to acquire the contracts at their final maturity and assumed the normal exchange-rate risks. The United States, however, guaranteed Italian authorities against any losses associated with dollar devaluation. This preferential guarantee posed a dangerous precedent for the United States (Board of Governors, 21 March 1966, 28-29).

Besides operations to provide cover, US monetary authorities frequently undertook forward transactions in an attempt to influence the premium of foreign exchange, and thereby to influence short-term financial flows. In 1964, for example, the forward discount of sterling narrowed, creating an opportunity for covered interest arbitrage. Funds began to move from New York to London. The Federal Reserve undertook a series of swaps with the market, buying sterling in the spot market and selling it forward. The operation apparently increased sterling's forward discount. These forward contracts, however, matured during a crisis in the sterling market, so that the Federal Reserve's eventual forward sterling sales conflicted with the Bank of England's objectives (Board of Governors, 21 March 1966, 26).

Although forward sales of foreign exchange typically left the Federal Reserve with an exposure, all Federal Reserve forward transactions between 1964 and 1971 proved profitable (Coombs 1971, 2). This largely stemmed from the nature of the operations under the Bretton Woods pegged-rate system. The Federal Reserve typically undertook forward transactions only when the foreign currency was selling at a substantial premium over existing spot rates, which fluctuated within 1 percent of their central parity. "In most cases" the Federal Reserve only undertook forward operations when the forward rate exceeded the spot rate's ceiling, as defined by the central parity (Coombs 1971, 2). Hence, the Federal Reserve was likely to profit, provided that the foreign country did not revalue its currency. Most countries offered the Federal Reserve revaluation guarantees similar to those that existed under the swap lines. Sometimes the Federal Reserve held sufficient foreign exchange balances to cover the operations even without a revaluation clause. On some occasions, as with German marks in 1971, the Federal Reserve drew foreign exchange on the swap lines when it sold that same foreign exchange forward (Coombs 1976, 3). The swap drawing covered the forward commitment, while the revaluation clause covered the swap repayment. Effectively, then, the revaluation clause extended to the forward commitment. On at least one occasion, to avoid supplying dollars to the Bundesbank, the Federal Reserve drew on the swap ninety days forward, a time consistent with a forward sale of German marks. The Bundesbank extended the revaluation clause to this "forward swap drawing" (Coombs 1971, 4-5). 


\subsubsection{IMF Drawings}

The ability to draw foreign currencies from the International Monetary Fund provided the US Treasury with an additional mechanism with which to temporarily forestall the drain on the US gold stock. Countries that are members of the International Monetary Fund (IMF) can buy (borrow) foreign currencies for intervention purposes against deposits of their own currency at the fund. The amount that any country can draw on the IMF (as well as its contributions to the fund and its voting rights within the organization) depends on that country's quota subscription to the fund. Countries initially paid 75 percent of their quotas in their domestic currency and 25 percent in either gold or dollars. In February 1965, the US quota in the IMF amounted to $\$ 4.1$ billion or 26 percent of the total (Yeager 1966, 348).

The IMF placed certain restrictions on countries' borrowing, although these restrictions were flexible. No members could borrow foreign currencies to such an extent that it increased the fund's holdings of the borrower's currency in excess of 200 percent of that country's quota. Since each country already paid 75 percent of its quota to the fund in its own currency, at most a country could incur foreign currency debts to the fund of 125 percent of its quota. In addition, no member's borrowings in any twelve-month period could increase the fund's holding of its currency by more than 25 percent of its quota. The rules implied that the fund could not compel a country, (i.e., a surplus country), to supply additional amounts of its currency to the fund, except in exchange for gold. Similarly, the IMF could not require a country to loan its currency to the fund to finance emergency borrowings (Yeager 1966).

The fund structured its loans to emphasize that they were intended for temporary balance-of-payments problems. The fund charged interest on borrowings in proportion to their size and duration and had myriad rules regarding repayment. Generally, however, countries had to repay loans within three to five years. In addition, regardless of the currency borrowed, all loans had to be repaid in either gold or a convertible currency. Often loans were provided under stand-by agreements that were in force for specific negotiated periods of time. The United States, for example, negotiated a one-year stand-by agreement in July 1963, on which it did not draw until February 1964. Countries could immediately borrow their "gold-tranche," an amount equal to the gold portion of their quota (normally 25 percent), and could borrow another 25 percent of their quota without much conditionality. Borrowings of additional amounts require members to undertake programs to restore balance-of-payments equilibrium.

Even though member states increased their quotas in 1959, the fund's resources were not sufficient to meet a large international crisis, particularly a speculative attack on both the US dollar and the British pound. The IMF, for example, lacked sufficient nondollar, nonsterling funds to meet the United States' notional right to borrow (James 1996, 162). On 2 October 
1962, ten major industrial countries (G10) agreed to stand ready to loan the fund their own currencies up to a total of $\$ 6$ billion equivalent for intervention purposes. ${ }^{60}$ The facility was known as the General Arrangements to Borrow (GAB). Loans would be in accordance with IMF policies, but required the consent of the lending countries.

Between 1964 and 1968, the United States undertook two types of drawings from the IMF, although both ultimately sought to avoid a possible drain of the US monetary gold stock. The first, often referred to as technical, stemmed from the reserve currency role of the dollar and from IMF rules governing how many dollars the fund could hold in its portfolio. Most countries that borrowed from the IMF held their foreign-exchange reserves in dollars and repaid their IMF drawings in dollars. By 1963, however, the IMF's dollar holdings had reached 75 percent of the US quota, and IMF rules precluded borrowing countries from repaying in dollars. The US policymakers feared that if these countries could not repay their IMF obligations in dollars, they would do so with gold purchased from the US Treasury. To avoid this possibility, on 13 February 1964, the US Treasury undertook the first in a series of foreign-currency drawings from the fund. In the initial drawing, the Treasury acquired $\$ 130.5$ million equivalent German marks, French francs, and Italian lira. These currencies were sold to a wide range of mostly developing countries for dollars. The Treasury undertook a second \$125 million equivalent drawing of German marks and French francs on 1 June 1964. Over the course of 1964, the Treasury made five such technical drawings in seven continental European currencies, totaling \$525 million equivalent. All but $\$ 75$ million equivalent was disbursed. In 1965 and 1966, the United States made additional technical drawings from the IMF (Desk Report 1965, 1966).

The United States also drew foreign currencies from the IMF to finance more normal adjustment operations. In 1965, many countries acquired dollar reserves that the Federal Reserve covered through the swap mechanism, but because of continuing pressures on dollar exchange rates, the prospect for repaying these swaps became slim. On 30 July 1965, the United States made a $\$ 300$ million equivalent, medium-term, multicurrency drawing on the IMF. The drawing consisted of $\$ 180$ million equivalent Italian lira, $\$ 40$ million French francs, $\$ 40$ million Belgian francs, $\$ 25$ million Dutch guilders, and $\$ 15$ million Swedish kronor. The Treasury made the Belgian francs and most of the Italian lira available to the Federal Reserve to help retire outstanding central bank swap commitments. This was the first IMF drawing explicitly for the purpose of retiring Federal Reserve swap debts. The Treasury used the remainder of the drawing to absorb dollars at foreign central banks (Desk Report 1966, 39). In August 1966, the Treasury borrowed \$250 million equivalent Italian lira from the fund and sold the proceeds to the Federal Reserve to refund swap obligations with the Bank of Italy and with the BIS. Because the fund was short of lira at the time of 
this drawing, the fund borrowed lira from the Italian government under the General Arrangements to Borrow. This was the first time that the Fund borrowed foreign currencies under the GAB. In early March 1968, the United States drew \$200 million equivalent in foreign currencies under its gold tranche with the IMF and sold these currencies to the Federal Reserve to cover outstanding swap obligations.

\subsubsection{Roosa Bonds}

The Treasury often acquired foreign exchange to finance its intervention operations by issuing nonmarketable foreign-currency-denominated securities to foreign central banks or foreign governments. By holding such securities instead of dollars, foreign central banks were covered against the possibility of a dollar depreciation. Prior to the fall of 1962, the Treasury offered short-term debt instruments - certificates of indebtedness - to foreign central banks and governments. In November 1962, the Treasury began issuing longer-term nonmarketable securities to foreign central banks and governments, so-called Roosa bonds after Undersecretary of the Treasury, Robert Roosa. Initially the Roosa bonds were nonconvertible, but to make them more attractive to the legal and portfolio needs of foreign central banks, they became convertible on short notice into redeemable claims (Yeager 1966, 449). Often the Treasury sold the proceeds from Roosa bonds to the Federal Reserve, enabling the latter to retire outstanding swap debts. The US Treasury had \$298 million worth of outstanding foreign currency denominated securities at the end of 1962. These consisted of Italian lira bonds ( $\$ 200$ million) and Swiss franc bonds ( $\$ 98$ million). The total outstanding balance of all Roosa bonds would grow to $\$ 1.7$ billion by the end of 1972. Although the Treasury generally maintained a negative net open position prior to the late 1970s, the Treasury often attempted to cover the exposure associated with outstanding bonds. ${ }^{61}$ Its early operations in Italian lira afford an example.

In 1962, the US Treasury issued a series of three-month certificates denominated in Italian lira totaling \$150 million equivalent, and used the proceeds to finance forward lira sales to Italian commercial banks. Later in the year, the Treasury issued $\$ 200$ million equivalent in fifteen-month lira-denominated Roosa bonds to retire the three-month certificates and to drain unwanted dollars that the Bank of Italy held. In late 1963, when the lira came under downward pressure and the Bank of Italy wanted to augment its dollar reserves, the US Treasury bought lira outright from the Bank of Italy. This purchase provided the Treasury with partial cover for its outstanding lira bonds.

In November 1963, Coombs asked the FOMC for permission to purchase foreign currency in which the Treasury had outstanding indebtednessmost immediately in Italian lira - at rates above par, if necessary, and to sell the currency forward to the Treasury to cover its outstanding indebtedness 
(FOMC Minutes, 12 November 1963, 5-9). With the spot purchase from the market and the forward sale to the Treasury at the same exchange rate, the Federal Reserve would be "warehousing foreign currencies without capital risk until they were needed by the Treasury, whose resources for this kind of operation were limited." (FOMC Minutes, 12 November 1963, 7) ${ }^{62}$ The lira that the Federal Reserve purchased and sold to the Treasury enabled the Treasury to redeem a maturing $\$ 50$ million lira bond and prepay the remaining $\$ 150$ million bonds outstanding.

\subsection{Before the Fall: Cross-Rate Problems and the Gold Pool}

Neither US macroeconomic policy nor the dollar's unique reserve currency role within the Bretton Woods system contributed directly to the devaluations of the British pound in November 1967 and French franc in August 1969, or to the revaluation of the German mark in the following October. These cross-rate adjustment problems stemmed largely from local developments - poor British macroeconomic policies, French social problems, and persistent German gains in competitiveness (Solomon 1982, 158). Nevertheless, changes in pound, franc, and mark exchange rates posed a general threat to the Bretton Woods parity structure. The associated uncertainty created speculative financial flows that caused other central banks to accumulate unwanted dollar reserves, and that affected other exchange rates and the gold market. United States operations in these markets amply illustrate the successes and failures of foreign-exchange-market operations during the Bretton Woods era. They show continuous, often complicated, back-and-forth, buy-and-sell operations, which frequently seemed to successfully delay parity changes, but in the end failed to solve the underlying problems.

\subsubsection{The Devaluation of the UK Pound}

In addition to protecting US gold reserves and shoring up the dollar, US intervention operations between 1962 and late 1967 aimed at providing support to the UK pound.$^{63}$ At the time, the pound was the second most widely held reserve currency, but observers increasingly questioned the viability of the pound's parity because the United Kingdom's competitive position had deteriorated since the war and its reserve position seemed low relative to its emerging balance-of-payments deficits (Cairncross and Eichengreen 2003). By 1963, the pound was subject to Triffin's paradox; the value of outstanding pound claims exceeded the United Kingdom's foreign-exchange reserves (Bordo, MacDonald, and Oliver 2010). Despite being in fundamental disequilibrium, massive amounts of foreign assistance between 1962 and 1967 helped the United Kingdom to hide its low level of reserves and maintain the pound's peg. The peg eventually collapsed when foreign governments ended their rescue efforts. 
The pound's weakness presented US monetary authorities with two closely related problems. First, financial flows from the United Kingdom to Europe moved through US dollars, increasing dollar balances in European central banks and the prospects that these banks might convert the dollars into US gold. Second, US policymakers feared that if a sustained speculative run against the pound led to its devaluation, other countries would quickly follow. Pressure would then shift against the dollar's official gold price and seriously undermine, if not destroy, the credibility of the Bretton Woods system. The United States acted to support the pound (see figures 4.9 through 4.16 ).

After the Federal Reserve became actively involved in foreign-exchange operations in 1962, the pound experienced a series of speculative attacks. ${ }^{64}$ The first began after French President Charles de Gaulle rejected the United Kingdom's bid for membership in the European Common Market in late January 1963. The rejection quickly put downward pressure on the pound. Largely by fortunate circumstance, the Federal Reserve was buying $\$ 5.6$ million equivalent British pounds from the market to repay a January swap drawing when pressures against the pound started to build (see figures 4.9 and 4.10). ${ }^{65}$ The Bank of England also began intervening with the dollar proceeds of the same swap drawing, but the pound continued to depreciate and fell below par. In response, the US Treasury entered the fray, purchas-

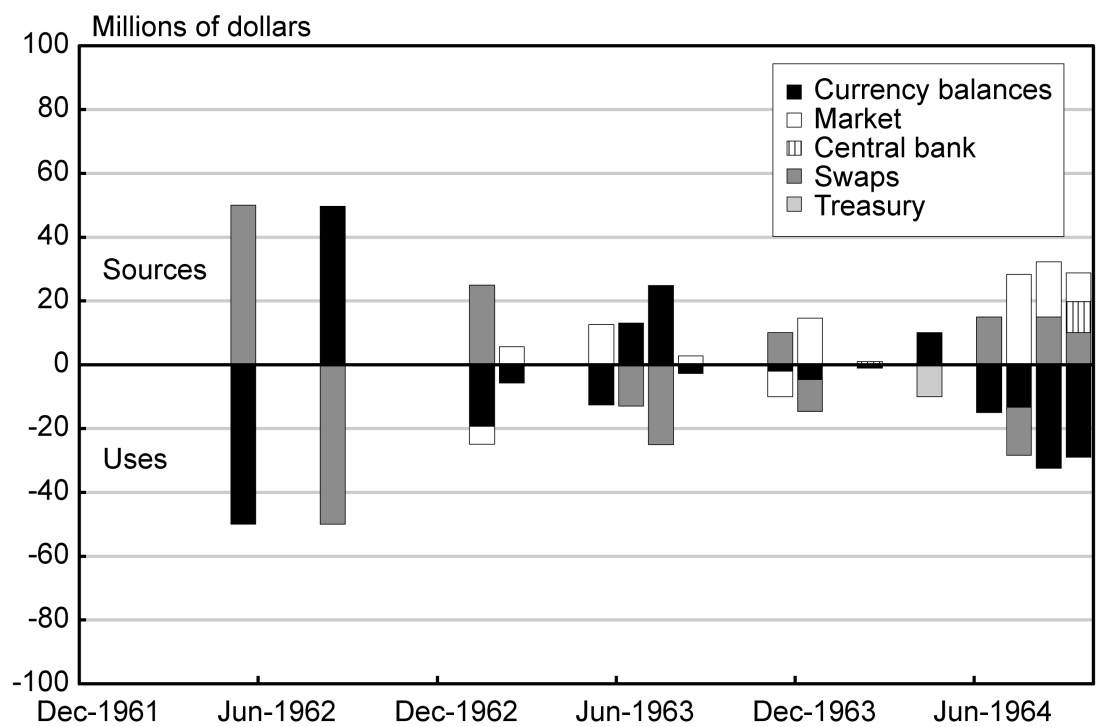

Fig. 4.9 Federal Reserve sources and uses of British pounds, December 1961-September 1964

Notes: "Central bank" contains "exceptional items." Data do not include unexplained items or profits. Data are from the Federal Reserve System. 


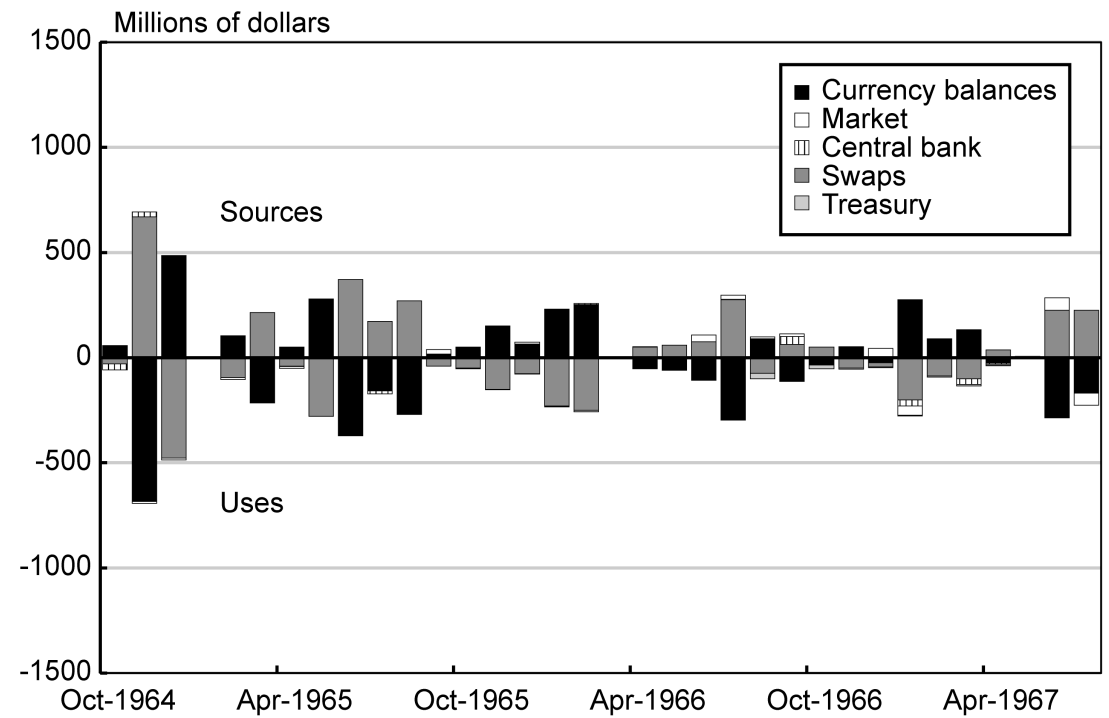

Fig. 4.10 Federal Reserve sources and uses of British pounds, October 1964July 1967

Notes: "Central bank" contains "exceptional items." Data do not include unexplained items or profits. Data are from the Federal Reserve System.

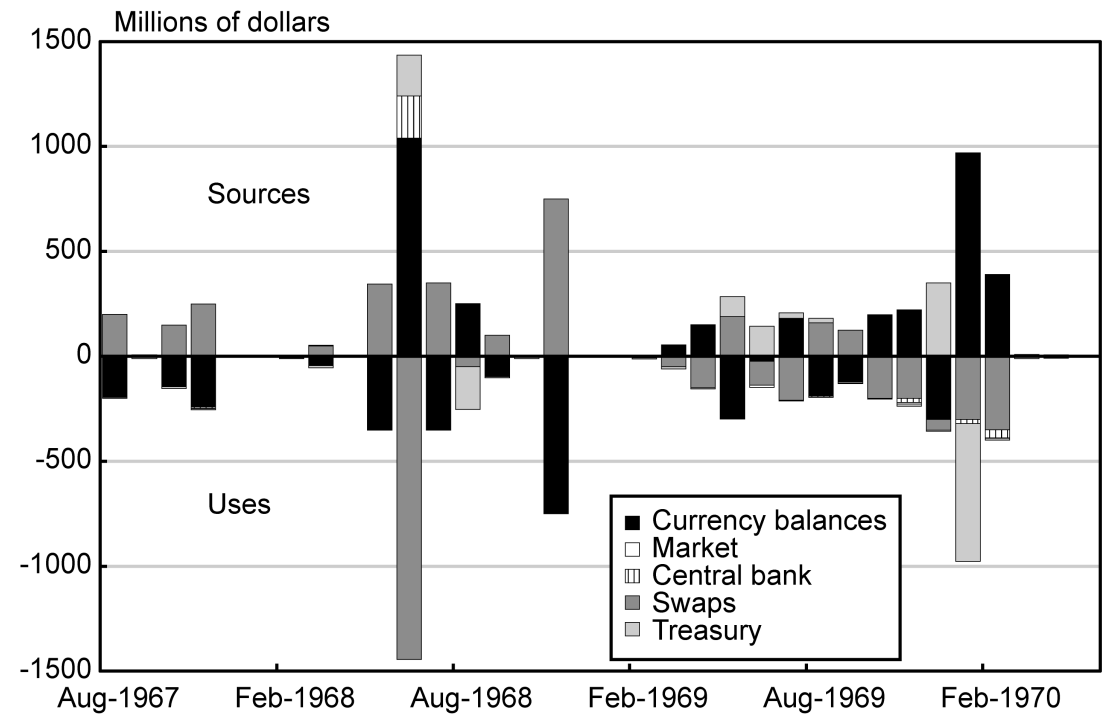

Fig. 4.11 Federal Reserve sources and uses of British pounds, August 1967May 1970

Notes: "Central bank" contains "exceptional items." Data do not include unexplained items or profits. Data are from the Federal Reserve System. 


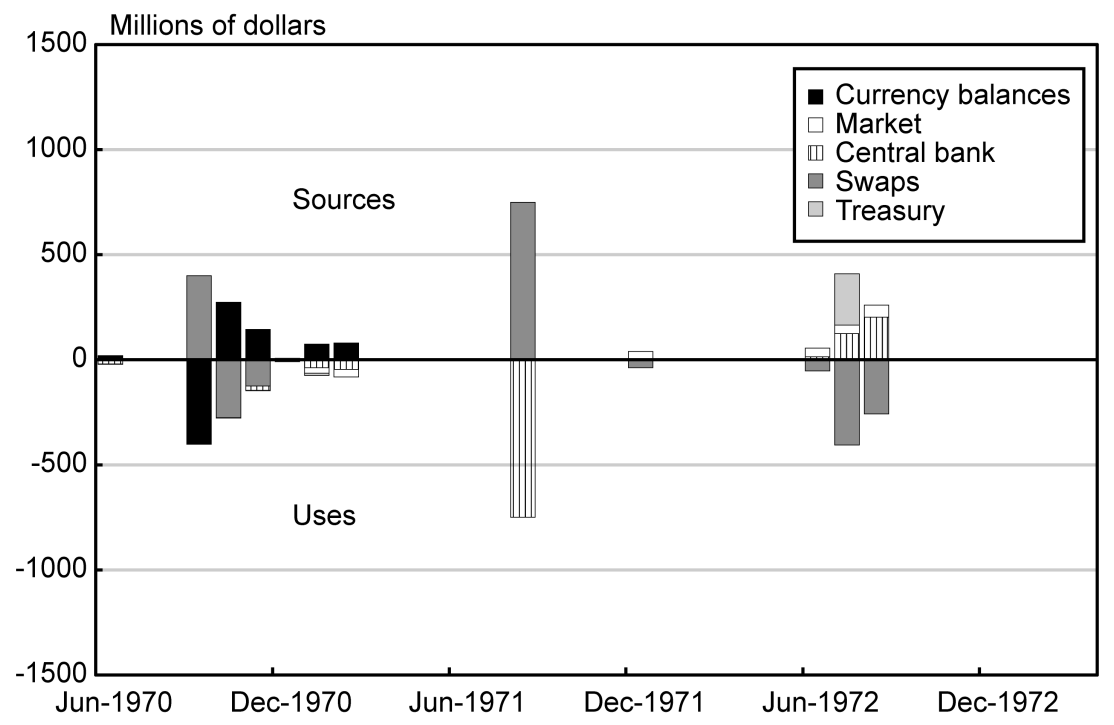

Fig. 4.12 Federal Reserve sources and uses of British pounds, June 1970May 1973

Notes: "Central bank" contains "exceptional items." Data do not include unexplained items or profits. Data are from the Federal Reserve System.

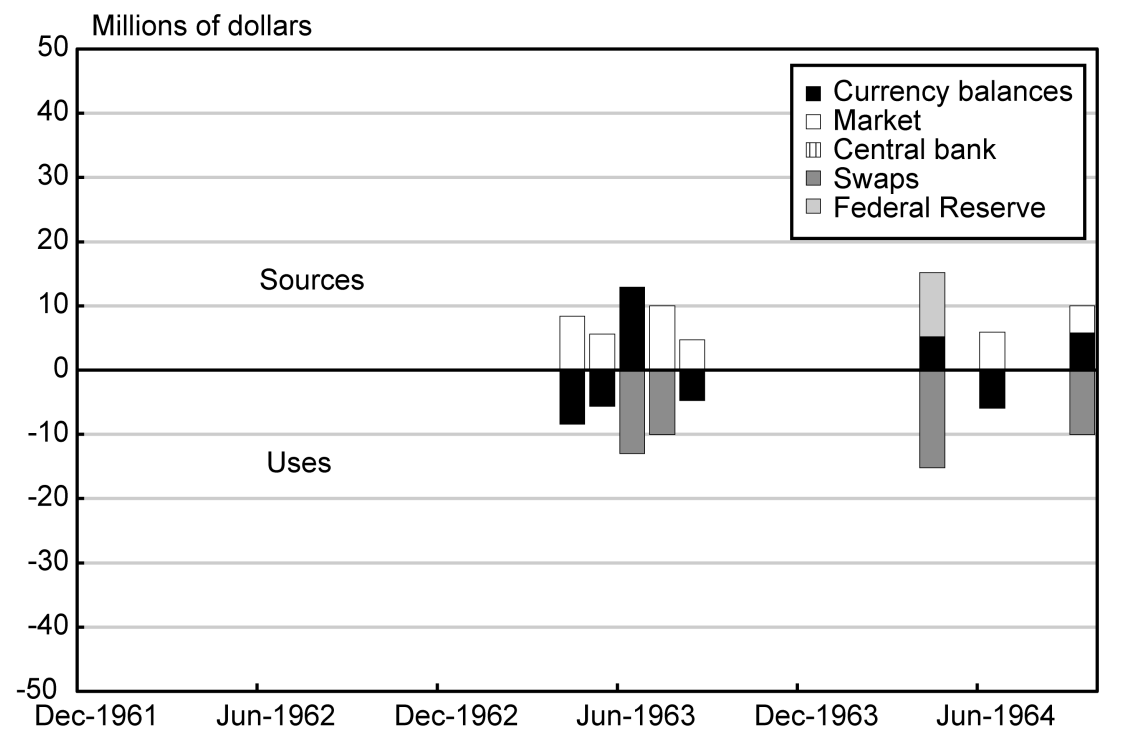

Fig. 4.13 US Treasury sources and uses of British pounds, December 1961-September 1964

Notes: "Central bank" contains "exceptional items." Data do not include unexplained items or profits. Data are from the Federal Reserve System. 


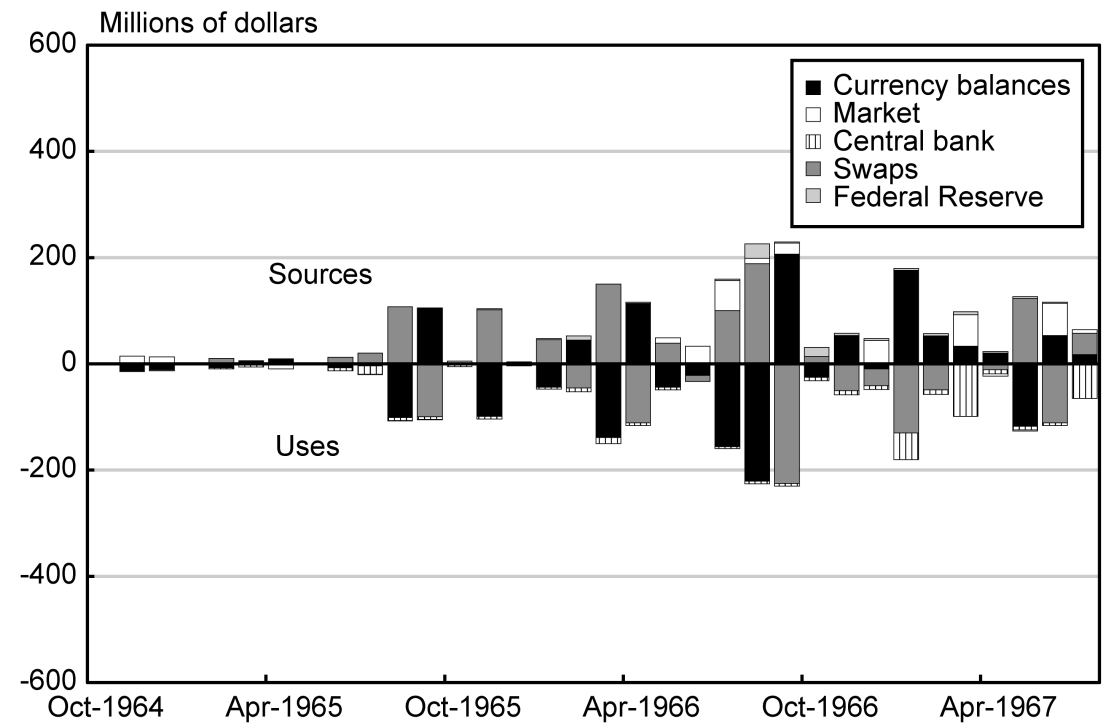

Fig. 4.14 US Treasury sources and uses of British pounds, October 1964July 1967

Notes: "Central bank" contains "exceptional items." Data do not include unexplained items or profits. Data are from the Federal Reserve System.

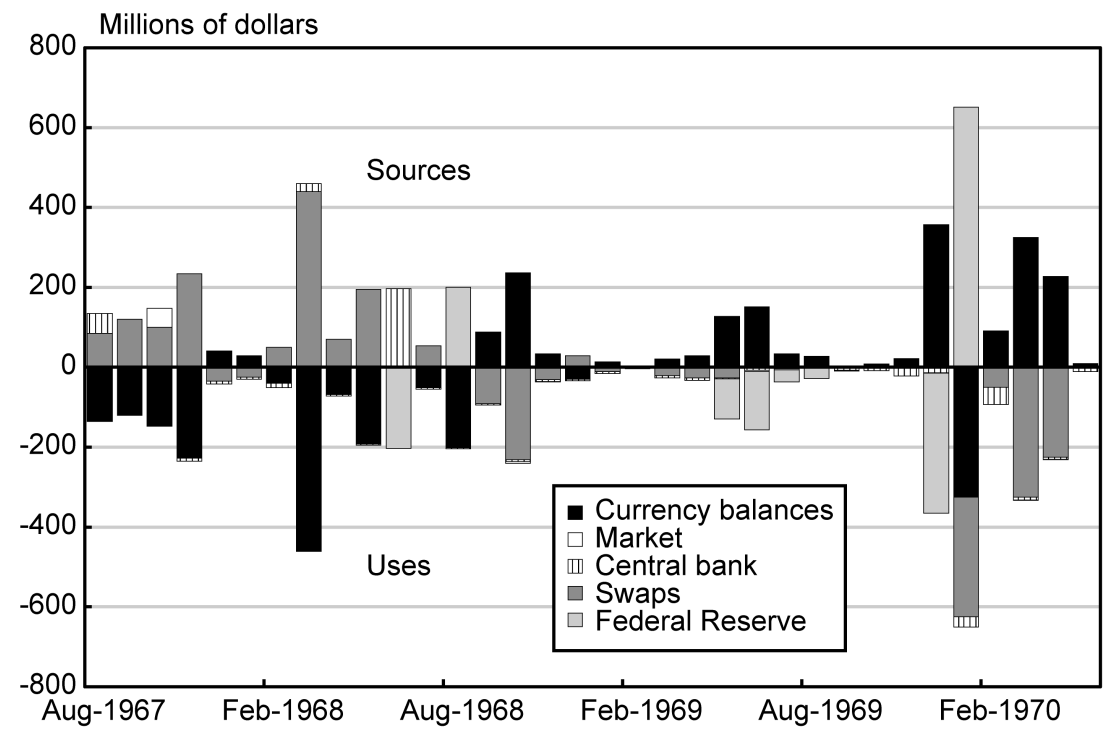

Fig. 4.15 US Treasury sources and uses of British pounds, August 1967-May 1970 Notes: "Central bank" contains "exceptional items." Data do not include unexplained items or profits. Data are from the Federal Reserve System. 


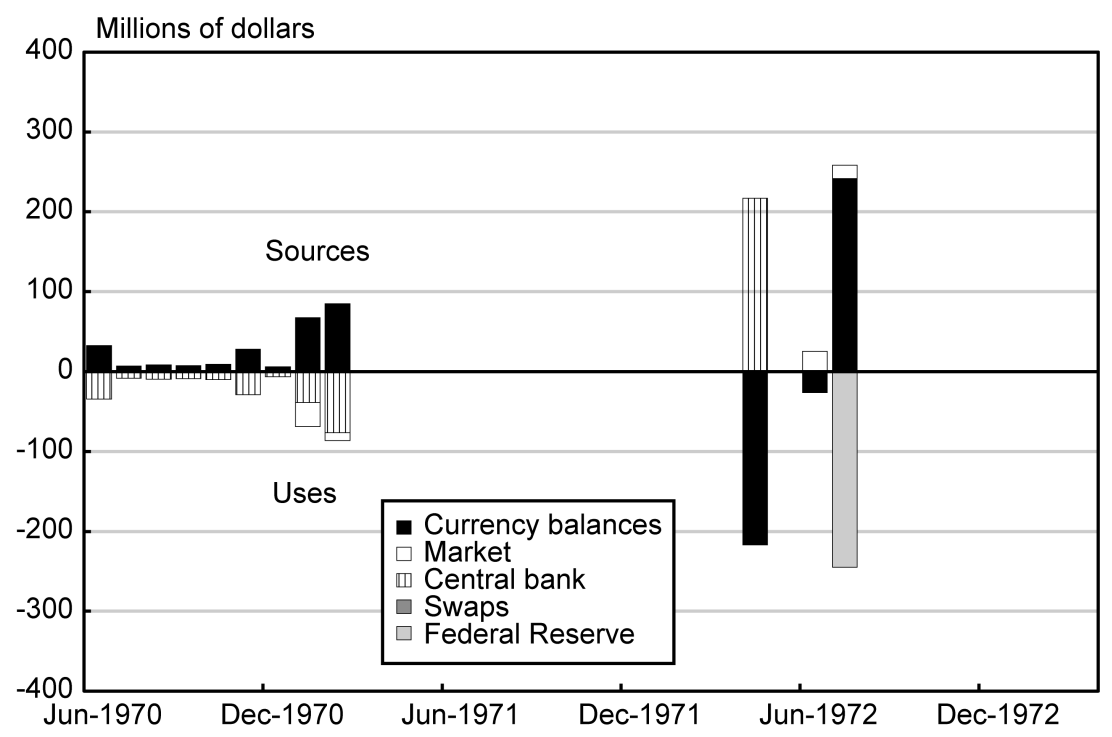

Fig. 4.16 US Treasury sources and uses of British pounds, June 1970-May 1973

Notes: "Central bank" contains "exceptional items." Data do not include unexplained items or profits. Data are from the Federal Reserve System.

ing \$8.4 million worth of pounds in the market on 29 March 1963 (Bulletin, September 1963, 1219).

The speculative outflow from the United Kingdom caused other European central banks to acquire dollars. Consequently, instead of drawing down additional dollars from its US swap line to defend the pound, the United Kingdom negotiated \$250 million worth of short-term credits with continental European central banks to shore up its potential reserves $(\mathrm{Bul}$ letin, September1963, 1219). Britain negotiated these credits in early February, but did not make them public until April 1963. The announcement of the cooperation among central banks took much of the pressure off the rate by signaling a rise in the potential cost of speculating against a pound devaluation. The pound soon rose above par.

With pressure on sterling waning, US monetary authorities took opportunities to retire their outstanding swap debt, and in the bargain, to support the pound. On 19 May 1963, in a further move to raise the potential cost of speculation against sterling, the Federal Reserve announced an increase in its swap line with the Bank of England from $\$ 50$ million to $\$ 500$ million (Bulletin, September1963, 1220). In considering this ten-fold increase, one FOMC member feared - quite rightly, as we have already seen - that if the Bank of England drew on the swap lines to defend the pound, the dollars thus expended might show up as unwanted dollar reserves on the books of 
other central banks (FOMC Minutes, 28 May 1963, 17). The generous swap lines with the Bank of England thus presented a prospective problem for the United States down the road.

In early 1964, the pound again came under pressure because of a deterioration in the British balance of payments, uncertainty about the timing and outcome of upcoming elections, and rumors of a possible revaluation of the German mark. Bank of England interventions, sometimes undertaken in concert with the Federal Reserve and the US Treasury, increased markedly. On 30 June, the Bank of England drew $\$ 15$ million from the swap line with the Federal Reserve System, but quickly repaid the drawing in July when money-market conditions provided the pound with a respite.

In July 1964, covered interest arbitrage conditions favored a movement of funds into London. To forestall financial outflows from New York, the Federal Reserve undertook a series of swap transactions with the market designed to increase the forward discount on UK pounds by buying pounds spot against dollars and simultaneously selling them forward. These market swaps amounted to \$28 million equivalent in July. In addition, the US Treasury offered $\$ 1$ billion worth of Treasury bills on 22 July in an Operation Twist effort to raise short-term interest rates relative to long-term rates (Bulletin, September 1964, 1123). Nevertheless, covered interest arbitrage conditions continued to favor placing funds in London, and the Federal Reserve undertook additional market swaps in New York totaling \$26.2 million equivalent in late August and early September (Bulletin, March 1965, 379). Many of these forward sales would eventually come due when speculative pressures were weighing on the pound. The Federal Reserve would then find itself making spot sales of pounds in a weak market.

In August 1964, sterling started weakening relative to other European currencies and funds again began to shift out of pounds into the Eurodollar market. Britain negotiated a $\$ 1$ billion standby credit with the IMF, and in September, British monetary authorities arranged a $\$ 500$ million multicountry series of swaps with several European central banks and the Bank of Canada. "By the end of September, the Bank of England had drawn \$200 million of the $\$ 1$ billion of [international] swap credits available" (Solomon 1982, 87). (The $\$ 1$ billion credit line included the Federal Reserve's swap line.) The Bank of England embarked on a series of almost continuous swap drawings and repayments with the Federal Reserve that continued through August 1965.

Britain elected a Labour Party government on 16 October 1964 by a narrow margin. Although opinions within the government were divided, the prime minister and much of the cabinet opposed any devaluation of the pound (Cairncross and Eichengreen 2003). Nor would the Labour government deflate the economy. Prime Minister Harold Wilson's preference for renationalizing industries and expanding the welfare state instead sent financial funds flowing out of the country (Cairncross and Eichengreen 2003). 
Within ten days of taking office, the new Labour government announced measures to deal with the country's growing balance-of-payments problem. These included a 15 percent import surcharge and export tax credits, which quickly resulted in threats of reprisals (Bulletin, March 1965, 380). The market anticipated an increase in the bank rate, but this did not immediately materialize. Finally on 20 November 1964, following another postponement of an increase in the Bank of England's discount rate, a massive selling wave began. On that same day, the United Kingdom exhausted its credit line with the Bank of Canada and with the other European central banks and drew \$350 million from its swap line with the Federal Reserve (Coombs 1976, 114). On Monday, 23 November 1964, the Bank of England increased its bank rate from 5 percent to 7 percent, but with the market now anticipating a pound devaluation, selling pressures became especially heavy.

On 24 November 1964, a \$3 billion short-term credit package to back up sterling began to take shape (Coombs 1976, 116-23). The FOMC approved a \$250 million increase in the swap arrangement with the Bank of England to $\$ 750$ million. The Bank of England had been drawing on its swap line since August, and had even sold \$50 million in gold to the US Treasury. The Export-Import Bank - a frequent participant in US exchange-market intervention efforts - authorized $\$ 250$ million in credit (Coombs 1976, 117). Ten other central banks and the BIS participated, creating a $\$ 2.5$ billion shortterm credit facility. Although France grudgingly participated, President De Gaulle claimed it would be the last time (Solomon 1982, 89). During late 1964 - and throughout much of 1965 - the Bank of England continued to draw on its swap line with the Federal Reserve and to make simultaneous repayments. In total, the Bank of England drew $\$ 1.4$ billion between June and December 1964. ${ }^{66}$ The multinational short-term credit lines facilitated the swap repayments. Eventually, the United Kingdom made a \$1 billion multicurrency drawing from the IMF in December 1964 to help with repayments.

By late 1964, the United Kingdom was borrowing from some creditors to repay others, but the country had not addressed its fundamental underlying balance-of-payments problem. As Coombs $(1976,123)$ concluded: "In any event, the provision of $\$ 3$ billion of new credits to the Bank of England signally failed to generate a real recovery of confidence in sterling." Although the crisis atmosphere lightened, uncertainty about the United Kingdom's trade deficit and its economic policies left the pound under downward pressure throughout December. Heavy interventions - particularly in the forward market - continued (Coombs 1976, 123; Cairncross and Eichengreen 2003, 171). The Bank of England sold an additional $\$ 75$ million in gold to the US Treasury in December to acquire dollars for intervention.

Britain's balance-of-payments deficits persisted in 1965, as did speculative attacks against sterling and heavy intervention. On 25 May 1965, with reserves and credit lines nearly exhausted, the Bank of England again drew 
$\$ 1.4$ billion equivalent in foreign currencies from the IMF and Switzerland, and repaid $\$ 1.1$ billion equivalent in outstanding short-term credits. The bank's $\$ 2$ billion credit line with other central banks then terminated (Coombs 1976, 124). The Bank of England increasingly found itself attempting to defend a parity that many market participants and even official observers viewed as untenable.

After a brief midyear respite, pressure on sterling returned because of tightness in the Eurodollar market and because the Bank of England had lowered its discount rate. The Bank of England was again intervening in both spot and forward markets for sterling. These operations intensified in August following the release of unfavorable reserves figures. By August, the Bank of England had drawn the full $\$ 750$ million on the Federal Reserve's swap line. On 31 August 1965, the Federal Reserve and Treasury extended a special one-day $\$ 140$ million credit to the Bank of England that allowed the bank to bolster its reserves on a single day for reporting purposes (FOMC Minutes, 31 August 1965, 4). Henceforth, swaps would occasionally serve this function.

Following notification that the government obtained some wage and price controls, the market again settled down, but the pound remained susceptible to downward pressure. British reserves were now very low, and existing short-term credit facilities with the United States and with the IMF were fully drawn. Britain entered into new credit arrangements totaling $\$ 600$ million with Canada, Japan, and the key European central banks. ${ }^{67}$ France did not participate. For its part, the United States agreed to buy $\$ 400$ million worth of pounds either on a guaranteed basis, which meant that in the event of a sterling devaluation, the Bank of England would repurchase the sterling at the initial exchange rate, or otherwise on a covered basis (Coombs 1976, 126-27; FOMC Minutes, 8 September 1965, 1-6). The announcement was made on 10 September 1965 at the opening of the New York market. The Bank of England in concert with US monetary authorities immediately began purchasing sterling in New York "on a substantial scale and at progressively higher rates so as to convince the market of the determination and power of the central banks in support of sterling" (Desk Report 1965, 13). The desk operated directly with the market, not through the brokers' market with a commercial bank as its agent, as typically had been the case (Coombs 1976, 128). ${ }^{68}$ The Federal Reserve purchased \$21.5 million worth of pounds on a "guaranteed basis." The pound rose above par, and Coombs $(1976,129,131)$ viewed the operation as a successful "bear squeeze." The bears, however, did not die; they just hibernated for a while.

The enlarged international credit facility and a fortuitous improvement in Britain's balance-of-payments data checked the 1965 crisis. The Bank of England repaid \$275 million of its swap debts to the Federal Reserve in October and November. By year's end, the Bank of England had liquidated $\$ 760$ million of its forward market commitments and \$415 million of short- 
term obligations to the United States. In addition, the bank managed to increase its official reserves (Bulletin, March 1966, 321). Nevertheless, UK fundamentals remained shaky.

When the international credit lines came up for renewal in March 1966, the foreign central banks, which had lost faith in the United Kingdom's willingness to make fundamental adjustments, placed restrictions on their use (see Coombs 1976, 132-33). By then sterling-area governments were approaching the Bank of England, looking to convert their foreign-currency reserves out of sterling. The central banks that had participated in the September 1965 credit lines were willing to offer credits against the conversion of outstanding sterling reserve balances that foreign governments held, but not against continuing British balance-of-payments deficits. Moreover, the United Kingdom's drawings at any one time were not to exceed the amount of credits that the country still had available with the IMF. Essentially, the countries wanted an IMF backstop. At best, this was an insincere vote of confidence in the pound's prospects. The United States did not participate directly, but allowed the Bank of England to earmark a portion of the current US credit lines to finance reserve losses attributable to the conversion of sterling balances. ${ }^{69}$

In February 1966, the pound again fell below par, prompting renewed Bank of England intervention in the spot and forward markets. By April, the Federal Reserve and the Treasury joined in, often covering their portion through simultaneous forward pound sales to the Bank of England. Pressure on sterling intensified following a British seamen's strike in mid-May, tightening credit conditions in the Eurodollar market and continuing sharp declines in British reserves. United States intervention purchases of pounds in the last half of 1966 were exceptionally large.

On 20 July 1966, the British government announced a massive austerity program that included a wage freeze, restraints on prices and dividends, additional taxes, reduced travel allowances, and further curbs on public expenditures (Coombs 1976, 136). To signal confidence in the British program, the Federal Reserve and the Treasury made huge spot purchases of sterling totaling \$55.1 million equivalent and \$89.6 million equivalent, respectively, in June and July. (During the same month, however, the Federal Reserve and Treasury delivered $\$ 66.6$ million worth of pounds sold on a previous forward contract!) In addition, the Bank of England made a very large $\$ 100$ million swap drawing during the last statement week of July, bringing its entire monthly drawing to $\$ 300$ million. "In order that the [Federal Reserve] System's weekly statement would not reflect too large an increase in its 'other assets,' the System at the end of its statement week of July 27 swapped $\$ 88.2$ million pounds for one day with the U.S. Treasury" (Desk Report 1967, 10). The Federal Reserve now sought to hide the magnitude of its sterling operations from speculators. Heavy interventions continued throughout the summer. 
Although pressure on sterling began to subside in late summer, the situation remained critical. The prospects of once again getting the key central banks to provide the United Kingdom with credits to support sterling were now nil (Coombs 1976, 138-42). Consequently, the United States shouldered much of the burden. ${ }^{70}$ On September 13, the Federal Reserve announced a substantial increase, from $\$ 2.8$ billion to $\$ 4.5$ billion, in its entire swap facility. The swap-line extensions included an 80 percent increase in the Federal Reserve's line with Bank of England from $\$ 750$ to $\$ 1,350$ million. Coombs $(1976,141)$ described increases in the other swap lines as a "counterbalance," a necessary part of the sterling - and dollar-defense. If the pound came under speculative attack, the dollars expended to support sterling very likely would end up in the portfolios of other central banks. The Federal Reserve might then need to provide these banks with cover through swap drawings to protect US gold reserves.

During the second half of September 1966, following the announced hike in the swap lines, demand for sterling increased as dealers sought to cover forward sales and to cover short positions. The Bank of England began buying dollars at each opportunity to rebuild reserves. The desk undertook market swaps totaling $\$ 36.3$ million in November and $\$ 51.6$ million in December, with the proceeds split evenly between the Federal Reserve's and Treasury's accounts. Britain posted its first postwar trade surplus in November 1966, further alleviating the strains on sterling. For the year as a whole, British reserves actually increased.

In early 1967 , interest-rate differentials favoring pound-denominated assets continued to attract a financial inflow to Britain, despite that nation's overall weak trade performance. With its accumulated dollar reserves, by the end of March British authorities were able to repay its $\$ 510$ million obligation to the United States outstanding at the end of 1966, including $\$ 350$ million in swap obligations with the Federal Reserve, $\$ 50$ million in special overnight credits from the Federal Reserve, and \$130 million in special overnight credits with the US Treasury. In addition, the Bank of England repurchased \$33 million worth of sterling from the Federal Reserve and a substantial sum from the US Treasury. This reduced the Federal Reserve System holdings of sterling balances to $\$ 101.8$ million equivalent and the US Treasury's holdings to $\$ 120.9$ million equivalent. In addition, the Bank of England trimmed a November 1965 sterling-for-gold swap with the US Treasury to $\$ 33.8$ million. As this swap unwound, the US Treasury reduced a parallel gold-for-dollar swap with the Bundesbank. Full payment of these swaps was scheduled for June 1967 (Desk Report 1968, 10, fn.1). British authorities had also liquidated a substantial portion of outstanding credits from other monetary authorities.

This welcome break from speculation against sterling came to an end on 1 June 1967, when expectations of an imminent armed conflict in the Middle East caused a flight from sterling and a precautionary movement of funds 
out of the Eurodollar market. By 5 June, the Federal Reserve System and the US Treasury had purchased on a swap basis nearly $\$ 113$ million worth of sterling in the New York market, and the Bank for International Settlements drew $\$ 143$ million from the Federal Reserve's swap lines and placed the proceeds in the Eurodollar market to reduce interest-rate pressures. In early July, the Bank of England reported that it lost \$120.4 million in reserves during June (Bulletin, March 1968, 272). This report further eroded confidence in the pound. The loss would have been larger had the Bank of England not drawn on its swap line with the Federal Reserve and on the 1966 international credit arrangements. In addition the Swiss National Bank and Swiss commercial banks shifted funds to the London market to compensate for funds moved into Switzerland during the Middle East hostilities (Desk Report 1968, 14, fn. 5). The closing of the Suez Canal together with a British dockworker strike helped to worsen the British trade deficit.

On 19 October 1967, the Bank of England, hoping to reverse the financial outflows, raised its discount rate. In an effort to prevent a rise in the Eurodollar rates from nullifying the discount rate hike, the Federal Reserve drew on the swap line with the BIS, which then placed the dollar proceeds in the Eurodollar market (Bulletin, March 1968, 273). The Bank of England intervened heavily in both the spot and forward markets. The Treasury in concert with the Bank of England purchased spot sterling in an attempt to nudge the rate higher. By the end of October, the Treasury purchased $\$ 47.1$ million worth of sterling. The Treasury now held $\$ 194$ million equivalent pounds under the Bank of England's guarantee against devaluation. Despite these actions, selling pressure only intensified, prompting the Bank of England to raise its discount rate again on 9 November 1967.

On Thursday, 16 November 1967, Chancellor Callaghan, responding to questions from Parliament, refused to either confirm or deny rumors of plans for a massive sterling bailout, and prompted an unprecedented rush out of sterling the next day. The Bank of England lost more than $\$ 1$ billion in a single day (FOMC Memoranda, 27 November 1967, 8). On Saturday, 18 November 1967, the British government devalued sterling 14.3 percent to $\$ 2.40$. The Bank of England raised its discount rate to 8 percent (the highest level in 58 years), placed curbs on consumer installment credit, and asked commercial banks to channel credit toward exports. In addition, the government announced plans to cut public spending and to raise the corporate income tax (Bulletin, March 1968, 273-74).

Contrary to the expectations of US monetary officials, no other major industrialized country followed the British devaluation. Instead, they made more than $\$ 1.5$ billion in new short-term credits available to defend the new parity, and the IMF established a new $\$ 1.4$ billion standby facility. The Federal Reserve System and the US Treasury contributed $\$ 500$ million to this new facility (Desk Report 1968, 19).

The pound initially traded well above its new parity, but by the end of 
1967, it weakened on news of continuing British trade deficits and because of speculative gold purchases. On 8 December 1967, the Bank of England purchased sterling when the rate moved below \$2.41 (FOMC Memoranda, 12 December 1967, 5). By the end of 1967, the Bank of England had outstanding short-term commitments to the United States totaling \$1.6 billion, and large commitments to other monetary authorities (Desk Report 1968, 22).

During 1968 and 1969, the British pound generally remained under downward pressure, resulting in fairly persistent reserve losses. The exchange market remained skeptical of the Labour Government's commitment to the austerity measures that accompanied the November 1967 devaluation. In addition, the devaluation imposed losses on the reserve positions of sterling area countries, and these countries sought to protect themselves from another devaluation by diversifying out the sterling. Concerns about the Gold Pool (below) and the growing prospects of a mark revaluation or a franc devaluation heightened uncertainties about the long-term viability of the new sterling peg. Consequently, the Bank of England sought major credit lines both to fund continuing support operations and to meet commitments arising from outstanding forward contracts and previous credit lines. In 1968, England did receive additional international credits, bringing England's total credit facility to $\$ 4$ billion. The Federal Reserve System increased its swap line with the Bank of England by $\$ 500$ million to $\$ 2$ billion, and the US Treasury increased the credit facility that it extended to the Bank of England in November 1967 from $\$ 350$ million to $\$ 550$ million (see figures 4.9 and 4.10). In view of the severe strains on the official reserves, the United Kingdom elected to defer the year-end payment of principal and interest on postwar loans from the United States and Canada. This was the fourth postponement and left three such deferment options remaining (Cairncross and Eichengreen 2003, 193-94.)

The situation remained tenuous until late in 1969. The devaluation of the French franc on 8 August 1969 prompted heavy renewed selling pressure on the pound. The Bank of England drew on its swap line with the Federal Reserve in order to finance its support operations. Pressure on the pound continued until September, when balance-of-payments data show a surplus. Following the revaluation of the German mark, the pound began to strengthen, and the Bank of England acquired sufficient dollars to begin paying back its swap obligations. The pound traded just below parity and forward discounts narrowed. By December 1969, as Eurodollar rates dipped, the pound rose above par for the first time since April 1968. The Bank of England acquired dollars, which it used primarily to repay international credits. By early 1970, the Bank of England had fully liquidated its swap debt with the Federal Reserve and made strides at reducing other outstanding credits. On 5 March 1970, the Bank of England cut its discount rate from 7.5 percent to 7 percent. The Bank of England continued to pay down its outstanding 
debts throughout 1970. By April, for the first time since May 1964, the United Kingdom was free of all official debt (Cairncross and Eichengreen 2003, 194). The new exchange rate held until Bretton Woods ended.

\subsubsection{The Gold Pool}

Although the British devaluation did not lead to speculative attacks on other currencies, it did heighten speculative pressures in the London gold market. By March 1968, the Gold Pool disintegrated and a two-tier system of official and private gold prices replaced it.

After the United Kingdom reopened the London gold market in 1954, it rapidly reemerged as the largest, most important free market for gold in the world, and its daily fixing price became a barometer of confidence in the Bretton Woods (Bank of England 1964). Sufficiently large deviations between the London market price and the official gold price afforded central banks the potential for profitable arbitrage. The lower arbitrage point - the price at which buying gold in London and selling it to the US Treasury became advantageous - was approximately $\$ 34.80$ per ounce. This equaled the official $\$ 35.00$ per ounce less Treasury charges and shipping costs. The upper arbitrage point - the price at which buying gold at the official price in New York and selling it in the London market became profitable - was roughly $\$ 35.20$, the official price plus the Treasury fees and shipping costs. ${ }^{71}$ By and large, however, before 1965, the annual inflow of gold from new production and Russian sales typically accommodated private industrial, speculative, and official demands for gold, and if the London price deviated from the official price, the Bank of England could easily intervene to contain it within the arbitrage points (Bulletin, March 1964, 304), "by and large" here being the operative words.

This tranquillity first started to fade as the US presidential election approached in 1960. On 20 October 1960, the London gold price temporarily peaked at approximately $\$ 40$ per ounce. This price spike followed a brief shortfall in gold supplies and rise in speculative demand associated with uncertainty about the Kennedy administration's commitment to the official gold price. Speculators believed that the Kennedy administration would pursue easy, inflation-prone policies that would worsen the US balanceof-payments deficit and ultimately lead to a dollar devaluation. In response, the Bank of England acted to stabilize the market, with the support of the US Treasury's gold stock, and it drove the price down to $\$ 35.60$ by the end of the year (Coombs 1976, 57). The price of gold stabilized at approximately \$35.08 by March 1961, following Kennedy's pledge to maintain the dollar's convertibility, and in the second quarter of 1961, a series of fortuitous, but short-lived events that added to the supply of gold in the London market. These included Russian sales, Eisenhower's limitation on private US citizens' overseas gold holdings, and British gold sales following the German and Dutch revaluations. Still, events in October 1961 "badly jolted" confi- 
dence in the dollar, and central banks "could no longer forego the privilege [of converting dollars to gold] without exposing themselves to charges of imprudent management of the national reserves entrusted to their safekeeping" (Coombs 1976, 57).

Toward the end of 1961, however, South Africa and Canada reduced supplies to the market as they sought to build up their own reserves. Consequently, when the Berlin crisis unfolded, gold in London quickly began trading around the arbitrage point, $\$ 35.20$ per ounce. European central banks, concerned for the viability of the Bretton Woods system, refrained from buying US gold and selling it in London, but as demand from other central banks and from the private sector grew, the situation became extremely tenuous. Concerted action seemed necessary. The Gold Pool was the result.

The Gold Pool developed as a gentleman's agreement following the 1960 price spike in the London market (Bank of England 1964, 18). After a long period of informal discussions, mostly at the Basle meetings of central banks, in Ocober 1961 the United States proposed the formation of an informal sales consortium to limit gold-price increases stemming from political crises or speculative activity. The governments of Belgium, France, Italy, the Netherlands, Switzerland, West Germany, and the United Kingdom accepted the proposal and formed the Gold Pool. The initial subscription amounted to \$270 million worth of gold. The Bank of England acted as the consortium's agent in London and determined the appropriate amount of any sales. The United States, operating through the Federal Reserve Bank of New York, would match the gold sales of the other participating central banks. Hence, 50 percent of all Gold Pool sales involved US gold. The other central banks contracted to take set proportions of any gold sales up to their subscriptions. In addition, they agreed not to buy gold on the London market or from other sources, and they agreed not to quickly convert any excess dollars that they received from such sales into US gold. In November 1961, the Gold Pool undertook a trial run, selling a moderate amount of gold in London. When prices permitted, the Gold Pool repurchased this initial amount of gold and by the end of February 1962, redistributed it to the Pool's participants. The operations went smoothly.

In early 1962, however, gold prices began to fall, and following a proposal by the United States, the Pool began to purchase gold in the London market when the price approached the London gold export price. Now, instead of operating independently, the eight member nations bought gold in concert through the Gold Pool. By late spring 1962, the Gold Pool had purchased $\$ 80$ million worth of gold (Bulletin, March 1964, 306).

Even before the $\$ 80$ million could be distributed, a decline in US stock prices and speculative flight from Canadian dollars again pushed gold prices up. By mid-July 1962, the Gold Pool had used up its accumulated surplus, and by September 1962, the Pool had sold a net $\$ 50$ million worth of gold 
to the market. The Cuban Missile crisis in October 1962 resulted in record demands for gold, but substantial sales from the Pool helped keep the price below $\$ 35.20$. Subsequently, Russian gold sales helped drive the price down so that by the end of 1962, the Pool had recovered all of its net gold sales.

During 1963 and most of 1964, gold prices remained fairly stable. Speculative demand seemed to diminish, new production increased, and Russia sold gold to the market and to the Gold Pool. In both years, the Gold Pool acquired and distributed to its members $\$ 600$ million in gold (Bulletin, March 1964, 307; Bulletin, March 1965, 389).

Up to this date, the Gold Pool generally functioned as a successful stabilizing speculator might, by buying low and selling high around what appeared to be a sustainable official price. By late 1964, however, the situation began to change, and it would only worsen hereafter in accordance with Triffin's paradox..$^{72}$ In 1965, international tensions, stemming primarily from uncertainty about the viability of sterling's parity, from France's decision to accelerate the conversion of its dollar reserves into gold, and from that country's public criticisms of the Bretton Woods system, resulted in a very heavy speculative demand for gold. In addition, communist China bought large quantities of gold during much of the year. Even though sales from South Africa ran above normal, private demand absorbed almost all of this, and the Gold Pool found its resources dwindling as it struggled to keep the gold price below $\$ 35.20$. At one point early in the year, the Gold Pool operated with a $\$ 50$ million gold deficit, which the Bank of England financed out of its own reserves (FOMC Minutes, 2 February 1965, 6). Participants agreed to continue selling gold, and by June, the Gold Pool had a deficit of $\$ 170$ million (FOMC Minutes, 15 June 1965, 2). Nevertheless, with a good amount of "sheer luck," the Pool recouped its losses by the end of 1965 (Coombs 1976, 153).

Even though the Gold Pool was able to replenish reserves from time to time through supplies from South Africa or Russia, or through additional member contributions, demand generally continued to outpace supply through 1966. As American policymakers feared, demand for gold had become increasing tied to expectations about British sterling and, by extension, to the viability of the official gold price. Moreover, the French government, as Coombs noted, seemed intentionally to hasten the system's demise:

The French Government continued to harass the market with a succession of announcements designed to cast doubt on the official $\$ 35$ price. The latest French move in that campaign, announced on January 29, was to internationalize the hitherto domestic French gold market. Those new measures now permitted French residents to buy gold on the London market and would encourage the growth of French gold custody business for nonresidents. ... [T] he French seemed to have deliberately put themselves on a collision course with US policy ... (FOMC Minutes, 7 February1967, 3). 
Gold Pool losses increased after the 5 June 1967 outbreak of hostilities in the Middle East, requiring participating countries to contribute additional reserves to the Pool yet again. France, however, now balked at making a further commitment and withdrew, and the United States agreed to pick up their share. Other participating countries, notably Belgium and Italy, were losing confidence in the Gold Pool's viability and participants began to press the United States for a longer-term, fundamental solution to the problem.

The gold situation only worsened as the speculative attack on sterling continued. At the 14 November 1967 FOMC meeting, Coombs predicted that the Gold Pool would post a $\$ 600$ million to $\$ 700$ million deficit for all 1967 (FOMC Memoranda, 14 November 1967, 3). Since September 1966, the member countries had made eight contributions, totaling $\$ 670$ million in gold to the Pool, compared with an initial contribution of \$270 million. The seventh contribution had been negotiated on 8 November and had been virtually exhausted two days later. An eighth contribution was negotiated over 11 and 12 November (FOMC Memoranda, 14 November 1967, 3).

Coombs expected that the British Government would devalue the pound by 10 percent to 15 percent over the coming weekend unless they obtained massive support in the form of medium term credits (FOMC Memoranda, 14 November 1967, 4). He feared that a British devaluation would result in a run on gold, causing participants to withdraw from the Gold Pool. He expected that a financial flight from sterling would leave other European central banks with huge dollar inflows and add to the drain of US monetary gold. As the US Treasury lost gold, the market would lose confidence in the dollar.

Coombs's predictions did not immediately come true. Following the devaluation, Gold Pool members contributed a cumulative $\$ 1,370$ million to the operation. The US Air Force cooperated by airlifting gold from the United States to London. The Paris newspaper Le Monde, however, announced that the Bank of France had withdrawn from the Pool and that two other central banks (those of Belgium and Italy) were about to do the same (FOMC Memoranda, 27 November 1967, 3-6).

Foreign central bank operations in the Gold Pool, however, were only contributing to their further accumulation of dollars. Increasingly, Gold Pool participants believed that the United States should absorb those dollars through an IMF drawing, rather than via swap lines, and that it should take steps to plug the ultimate source of the dollar glut, the US balance of payments deficit, through monetary and fiscal policies (FOMC Memoranda, 12 December 1967, 17-19). The United States promised to intervene in defense of the dollar and to pay down any such foreign currency debts arising from these operations with drawings on the IMF (Coombs 1976, 171).

Speculative gold demand remained strong in early 1968, and on 17 March 1968 the London Gold Pool suspended operations. Between the devaluation of sterling (18 November 1967) and the closing of the London gold 
market (17 March 1968), the Gold Pool sold \$3 billion worth of gold in the London market (FOMC Memoranda, 2 April 1968, 4). "Of that total, the US share amounted to $\$ 2.2$ billion; both Italy and Belgium had replenished their share of Pool losses during March by buying gold from the US Treasury" (FOMC Memoranda, 2 April 1968, 5).

The seven leading central banks agreed to replace the Gold Pool with a two-tier gold market. Ideally, the existing stock of gold presently held as official reserves would be sealed off from the market. Monetary authorities would continue to buy and sell gold among themselves at the official price of $\$ 35$ per ounce, but they would refrain from transacting in the private market. With the establishment of special drawing rights (SDRs), they viewed the existing stock of official gold as sufficient for balance-of-payments purposes. All gold presently in private hands and all newly produced gold would remain outside of official reserves. Hence, the private price of gold could deviate substantially from the official price, and would become a highly visible barometer of confidence in the dollar and in the Bretton Woods system. Ironically, once the Pool dissolved, a large overhang of speculative gold reentered the market, holding the free market prices within $\$ 37$ to $\$ 40$ per ounce (FOMC Memoranda, 2 April 1968, 6).

Most other central banks and governments around the world signaled a willingness to cooperate with the two-tiered gold system. Some, of course, might not adhere strictly if the private and official prices greatly diverged. If the private market price fell below the official price, private gold producers would probably pressure their government to buy gold at the official price. Ultimately, however, the success of the venture depended on the triumphant adoption of SDRs, which could supply a nondollar reserve to satisfy future reserve needs, and on an improvement in the US balance of payments position, which could prevent a continued drain on US monetary gold stocks (Solomon 1968). These things, of course, would not happen.

\subsubsection{The Devaluation of the French Franc}

Between 1962 and early 1968, France became increasingly reluctant to cooperate in defense of the dollar. This reluctance stemmed from that country's fundamental displeasure with the dollar's role in the Bretton Woods system. The French government had long favored a fixed exchange-rate system that relied more heavily on gold for adjustment than did the Bretton Woods system and that did not confer unconstrained status on a single reserve currency (Bordo, Simard, and White 1996). As the provider of the reserve currency, the United States had sustained a balance-of-payments deficit, but - in accordance with Triffin's prediction - this made the system unstable. France realized this problem and believed that all countries should link their currencies directly to gold, not to the dollar, thereby making them potential reserve currencies, and that the United States should redeem dollars in gold (Coombs 1976, 174-75). 
France attempted to leverage US support for its preferred revisions to the international financial system by selling dollars back to the United States and sometimes by recommending an increase in the official price of gold. Between 1960 and 1968, France continued to increase the share of its official reserves held as gold, largely via dollar sales to the US Treasury. These dollar sales accelerated between early 1965 and the ending of the Gold Pool. In 1965, for example, French purchases accounted for more than two-thirds of the Treasury's gold sales to foreign countries. After the pound's devaluation in November 1967, hints of French support for an increase in the official gold price kept downward pressure on the dollar (Bordo, Simard, and White 1996).

Between 1962 and the collapse of the Gold Pool in March 1968, the Federal Reserve System only undertook three brief exploratory operations in French francs (see figures 4.17 and 4.18). As discussed above, in March 1962, the Federal Reserve established a \$50 million swap line with the Bank of France and drew $\$ 50$ million equivalent francs from that line largely to "test communications, investment procedures, and other operational arrangements" (Bulletin, September 1962, 1148). The Federal Reserve simply held these francs in its portfolio. After one renewal, the Federal Reserve liquidated the swap drawing on 12 August 1962. In May 1963, the Federal Reserve drew $\$ 12.5$ million equivalent French francs from the swap line and sold them for dollars in the Paris market. The Federal Reserve simultaneously covered this swap drawing by purchasing francs forward from the Bank of France. The desk was attempting to alter the level of the French franc-dollar exchange rate in a market that was not exhibiting compelling evidence of disorderly conditions nor under imminent threat of a speculative run. The US dollar had persistently traded at the lower parity band against the French franc, as large financial inflows contributed to a sizable French balance-of-payments surplus. The dollar rate, however, "showed no lasting sign of improvement" (Board of Governors 1966, 21). The Federal Reserve undertook a final operation in October 1963, which it financed with a $\$ 9.0$ million equivalent franc swap drawing. These operations gave the Bank of France discretion to sell francs as agent for the Federal Reserve (Bulletin, March 1964, 303). "Again, however, the underlying strength of the franc prevailed in the market; the dollar returned to the floor"; and the desk stopped intervening (Board of Governors 1966, 21). These operations were also covered through forward purchases of French francs, and the Federal Reserve liquidated the drawing in January $1964 .^{73}$

Over this same time period, the Treasury acquired French francs in conjunction with IMF drawings and briefly from a $\$ 25$ million swap with the Bank of England in December 1964 (see figures 4.19 and 4.20). Generally, the Treasury held these French francs or sold them to third parties. In August 1965, however, the Treasury sold $\$ 40$ million equivalent francs that it received from an IMF drawing to the Bank of France in order to reduce French acquisitions of US monetary gold. 


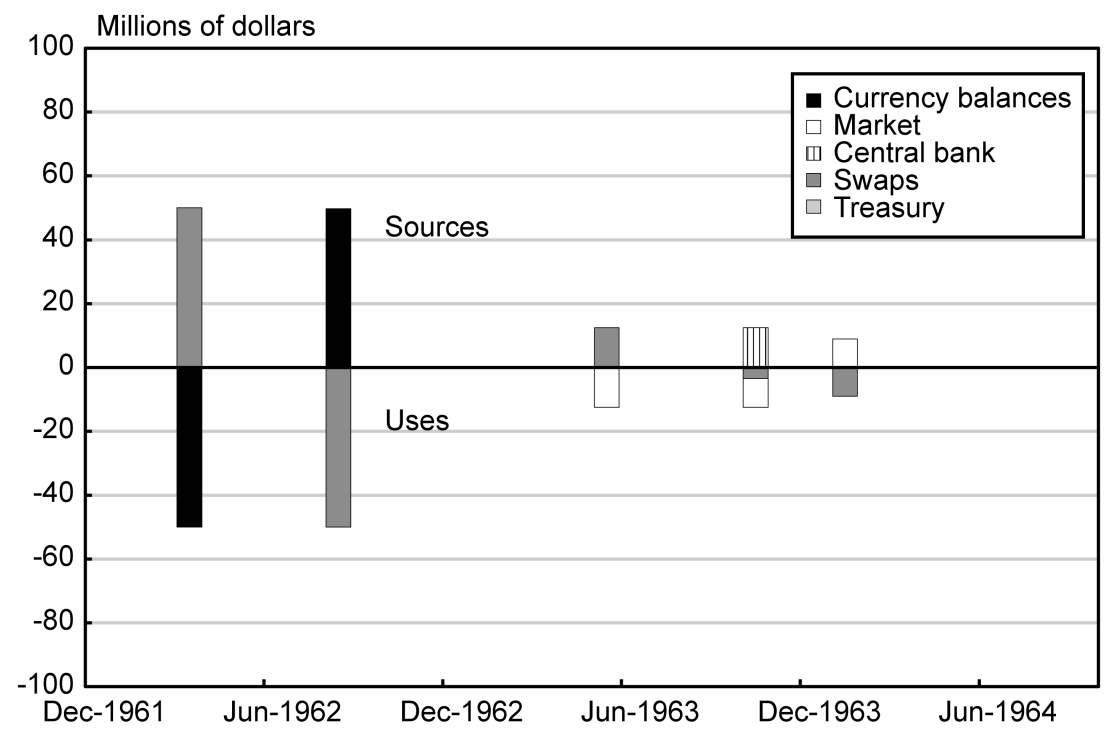

Fig. 4.17 Federal Reserve sources and uses of French francs, December 1961-September 1964

Notes: "Central bank" contains "exceptional items." Data do not include unexplained items or profits. Data are from the Federal Reserve System.

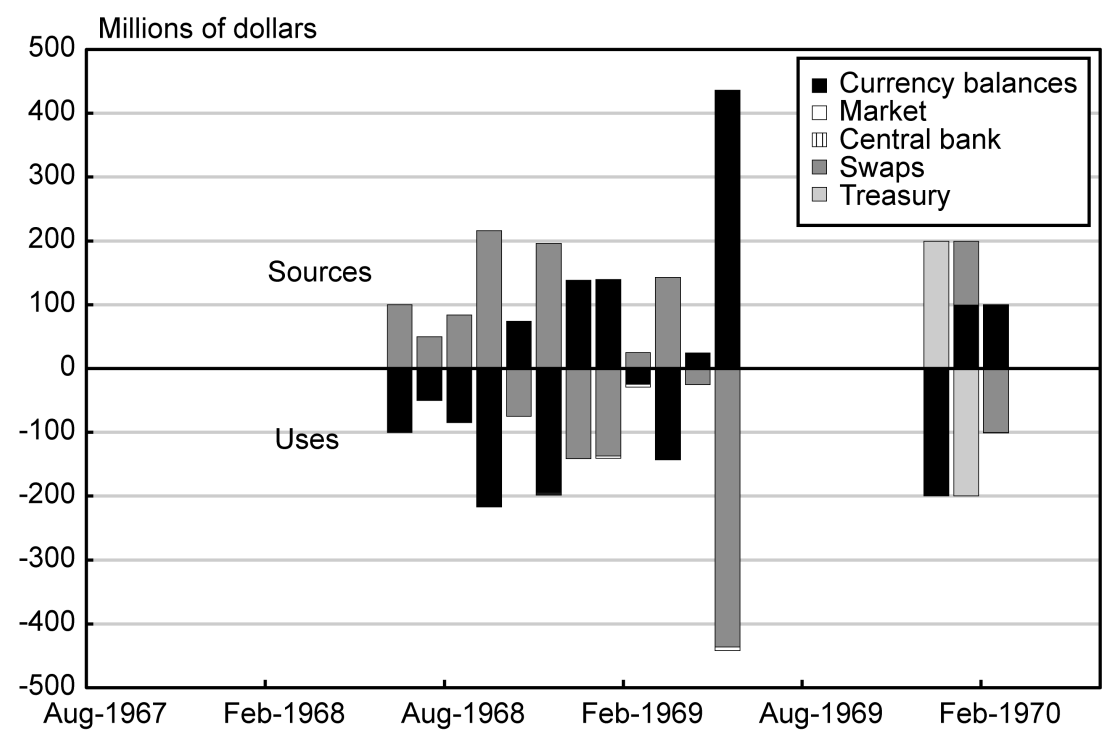

Fig. 4.18 Federal Reserve sources and uses of French francs, August 1967July 1970

Notes: The Federal Reserve did not transact in French francs between October 1964 and May 1968 nor between March 1970 and March 1973. "Central bank" contains "exceptional items." Data do not include unexplained items or profits. Data are from the Federal Reserve System. 
France's position as a strong-currency, surplus country came to an abrupt end in May 1968, when unexpected student rioting and labor strikes produced heavy financial flows out of French francs and into stronger currencies, despite the closing of most French financial institutions. The franc, which traded well above par throughout most of the 1960s, weakened precipitously. The Bank of France, whose operations were hampered by the closure of domestic financial institutions, asked the Federal Reserve System and the Bank for International Settlements to support the franc in the New York and European markets, respectively, for its account (Bulletin, September 1968, 728). By the end of the month, the French government imposed exchange controls on financial outflows and temporary import quotas. Export subsidies soon followed. In early June, President de Gaulle called for elections, which the Gaullists won.

Although the immediate political crisis began to subside in early June, the franc remained weak under fears that the Bank of France would accommodate the government's large wage concessions, thereby further eroding France's international competitiveness and forcing a franc devaluation. To finance a defense of the peg, the Bank of France - for the first time-drew the full $\$ 100$ million from its swap line with the Federal Reserve System in June 1968 (see figure 4.18). In addition, France drew $\$ 885$ million from the International Monetary Fund and sold gold from its reserves, including $\$ 220$ million of gold to the US Treasury (see figure 4.20). ${ }^{74}$ The Bank of France's net reserve losses amounted to $\$ 307$ million and \$203 million in May and June, respectively, but taking the various credits into consideration, the Federal Reserve estimated the total cost of supporting the franc over these two months at $\$ 1.5$ billion (Bulletin, September 1968, 729).

France undertook additional measures in July 1968 to shore up market confidence in the franc. Early in the month, the Bank of France raised its discount rate from $31 / 2$ percent to 5 percent and the French government tightened exchange controls and imposed new taxes. On 10 July 1968, the Federal Reserve System in concert with the central banks of Belgium, Germany, Italy, the Netherlands, and with the Bank for International Settlements, extended $\$ 1.3$ billion in additional credits to the Bank of France. For its part, the Federal Reserve increased its swap line by $\$ 600$ million to $\$ 700$ million (Bulletin, September 1968, 729-30). During July, August, and September 1968, the Bank of France drew an additional \$390 million from its swap line with the Federal Reserve, and financed the repayment of a small portion ( $\$ 40$ million) in August by selling $\$ 80$ million of gold to the US Treasury (Bulletin, March 1969, 218). Despite the show of international support, speculative pressure persisted, and the Bank of France continued to lose reserves in defense of the franc.

By the fall of 1968, growing rumors of an impending mark revaluation maintained speculation against the franc as some of the earlier credits were coming due. This forced the Bank of France into the awkward position of having to acquire dollars when the franc remained weak. In October, the 


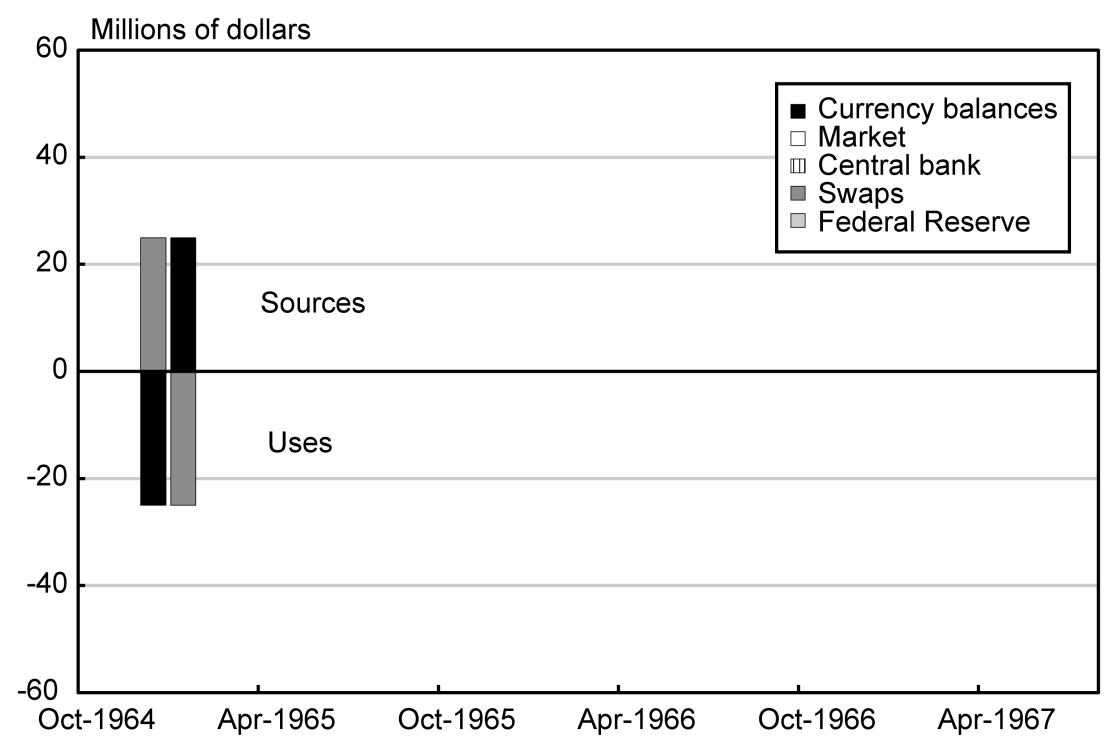

Fig. 4.19 US Treasury sources and uses of French francs, October 1964-September 1967

Notes: The US Treasury did not transact in French francs between December 1961 and September 1964. "Central bank" contains "exceptional items." Data do not include unexplained items or profits. Data are from the Federal Reserve System.

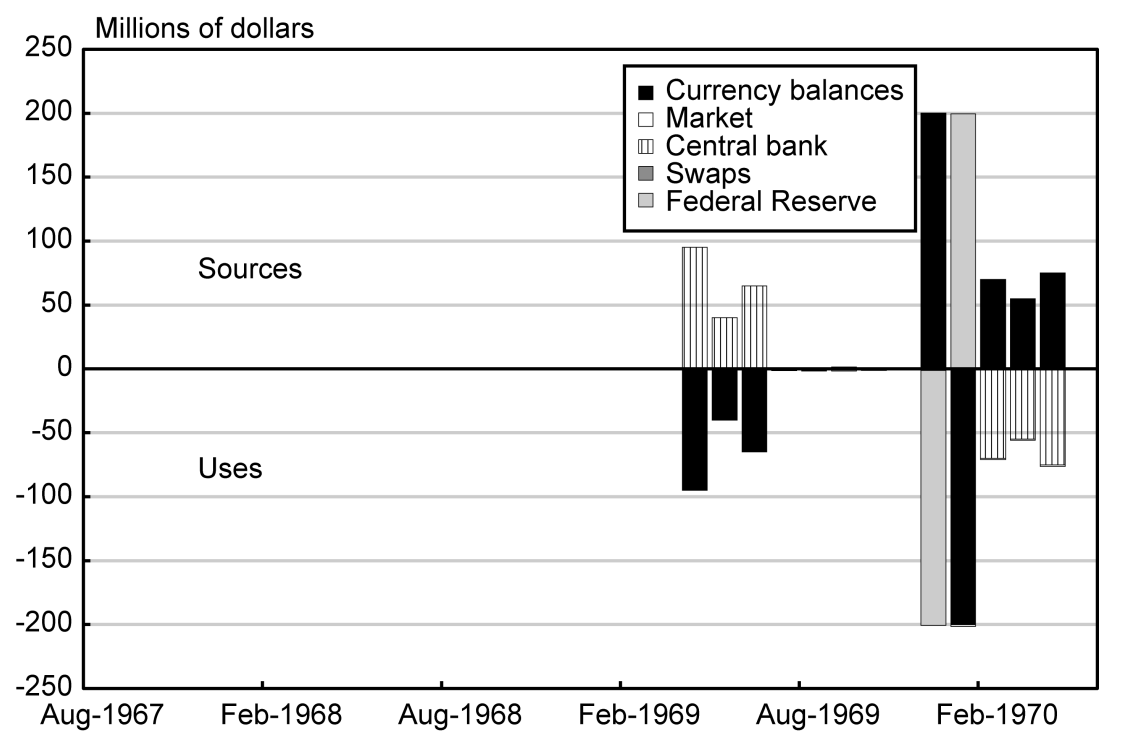

Fig. 4.20 US Treasury sources and uses of French francs, August 1967-May 1970

Notes: The US Treasury did not transact in French francs after April 1970. "Central bank" contains "exceptional items." Data do not include unexplained items or profits. Data are from the Federal Reserve System. 
Bank of France undertook dollar swaps with French commercial banks, simultaneously buying dollars spot and selling them forward. The bank then used $\$ 75$ million of the proceeds from these market swaps to reduce its official swap debt with the Federal Reserve System and to repay other international credits (Desk Report 1969, 50).

Rumors of a German mark revaluation intensified in November 1968, particularly after the Basle meeting of central bank governors, and encouraged huge movements of funds out of French francs and into German marks. The Bank of France sustained large reserve losses in support of the franc, which remained at its lower parity limit (Bulletin, September 1969, 706). In response, the Bank of France raised its discount rate 1 percentage point to 6 percent, tightened reserve requirements, and imposed credit controls on short-term bank lending. To keep the franc from breaching its floor value, the Bank of France intervened heavily during the first nineteen days of November 1968. In addition to drawing down its reserves, the Bank of France drew \$275 million on its swap line with the Federal Reserve and \$283 million from other international credits, and sold $\$ 110$ million in gold to the United States and \$140 million to other European countries (Desk Report 1969, 5153). In all, the seven-month crisis had significantly drained French reserves (Coombs 1976, 182). On 20 November 1968, France closed the market in Paris, as the G10 nations convened in Bonn to discuss the current situation.

At the Bonn meeting, the G10 ministers persuaded France to devalue the franc by 11.1 percent, but following the Bonn conference, President de Gaulle surprised the exchange market, which widely anticipated the devaluation, by rejecting the notion (Solomon 1982, 159-60). Instead, de Gaulle outlined a series of belt-tightening policies, including much stricter exchange controls. The G10 provided France with an additional $\$ 2$ billion in credits at the Bonn meeting. The United States' contribution consisted of a $\$ 300$ million increase in the Federal Reserve's swap line with the Bank of France (now at $\$ 1.0$ billion) and a new $\$ 200$ million credit facility through the Exchange Stabilization Fund (Bulletin, March 1969, 218).

Governors Brimmer and Maisel worried that if the Treasury provided credits to the Bank of France through a swap mechanism and subsequently warehoused those francs with the Federal Reserve System, the central bank would in effect be financing the credit to France. Coombs said that he would resist warehousing French francs (FOMC Memoranda, 26 November 1968, 22-23).

Largely because of stringent exchange controls, the Bank of France gained reserves from late November 1968 and through January 1969, which it used to repay credits. ${ }^{75}$ The Bank of France reduced its outstanding swap commitments with the Federal Reserve by \$220 million and paid down international obligations.

Expectation of inflation and devaluation persisted, and by February 1969, reserve gains attributable to exchange controls were not sufficient to fully finance the franc support operations. The situation worsened in March and 
in April on renewed labor unrest, and the Bank of France again started to lose reserves. To finance continued interventions, the Bank of France again drew $\$ 70$ million from its swap line in February and an additional $\$ 155$ million in March 1969. ${ }^{76}$ The bank also sold $\$ 50$ million in gold to the US Treasury (Bulletin, September 1969, 707).

President de Gaulle's resignation on 28 April 1969 did not stem the reserve losses, which if continued at their current pace, would exhaust the country's reserves by year's end. Many no longer believed that the franc's parity was viable, despite a further tightening of monetary policy in mid-June and George Pompidou's solid election victory. In May, as speculation on a mark revaluation intensified, francs sold forward, "with three-month contracts quoted at discounts as wide as 32 percent per annum before the forward market temporarily dried up completely" (Bulletin, September 1969, 707).

In May 1969, a deadline on swap credits again compounded the Bank of France's intervention operations. The bank owed $\$ 436$ million in swap debts to the Federal Reserve, as well as funds from drawings on other European credit arrangements. To service these obligations, the bank sold \$275 million in gold to the US Treasury and drew the remaining \$105 million available under the Treasury's swap arrangement (Bulletin, September 1969, 708).

Facing the prospect that its reserves would soon run out, France devalued the franc 11.1 percent on 8 August 1969 and instituted additional fiscal measures, credit restraints, and price controls to back up the new parity. The country had lost $\$ 500$ million per month in reserves during the last half 1968 and \$300 million per month during the first half of 1969 (Bulletin, September 1969, 708). The Bank of France also received additional international credits and applied for a standby credit of $\$ 985$ million with the IMF (Bulletin, September 1969, 708). Despite the devaluation, the franc remained under downward pressure, forcing France to further tighten its monetary policy.

Speculative pressures on the franc only began to unwind following the mark revaluation in October 1969. France's balance-of-payments position then began to shift from a large deficit to a surplus, and the franc moved from near its lower parity limit to near its ceiling. French authorities were able to repay $\$ 1.5$ billion in short-term international indebtedness, in part by drawing $\$ 985$ million from the IMF. In addition, the Bank of France removed some of its most restrictive exchange controls (Bulletin, September 1970, 701-03).

France continued to acquire reserves through 1971. Although the Bank of France eased monetary policy, French interest rates fell at a slower pace than US interest rates, and consequently encouraged a financial inflow. France used the additional reserves to continue to pay down its short-term international indebtedness. On 9 August 1971, the Bank of France paid off its IMF debt (Bulletin, March 1972, 246). Because France had to repay a portion of this debt in gold, that country bought $\$ 191$ million in gold from the US Treasury. 


\subsubsection{The Revaluation of the German Mark}

During the Bretton Woods period, Germany generally maintained a relatively tight monetary policy, ran fairly persistent trade surpluses, and experienced inflows of dollar reserves. Unlike many countries, Germany often refrained from converting dollar reserves into gold, as a means of compensating the United States for the American troops deployed on its soil. To some extent, this agreement freed US monetary authorities of the need to provide the Bundesbank with cover for excess dollar holdings. Nevertheless, the United States did undertake such cover operations from time to time with the US Treasury instead of the Federal Reserve, often playing the leading role. More often, however, US foreign-exchange operations tended to focus on influencing spot and forward mark-dollar exchange rates through direct interventions. Financing these operations through swap drawing proved difficult because the mark, which increasingly seemed undervalued, often traded above par and the FOMC's authorization precluded the desk from buying currencies above par.

To create an initial portfolio in early 1962-before the Federal Reserve established its \$50 million swap line with the Bundesbank - the Federal Reserve purchased \$32 million worth of German marks from the US Treasury (see figures 4.21 through 4.28). On 20 June 1962, with the German mark trading above parity, the Federal Reserve System began selling marks spot in the New York market. Between 1962 and 1966, the desk typically operated in the New York market after the European market had closed. Sometimes, however, the desk assumed all or part of the Bundesbank's intervention purchases of dollars in the European market (Board of Governors 1966, 22). This relieved the Bundesbank from holding additional dollar reserves. In late July 1962, just as the Federal Reserve began to intervene in concert with the Treasury, the mark began to ease against the dollar and afforded US monetary authorities with an opportunity to reconstitute their mark portfolios. At the end of September, the Federal Reserve and the US Treasury held open positions in marks equal to $\$ 31.2$ million and $\$ 31.7$ million, respectively. ${ }^{77}$ The Federal Reserve had not drawn on its swap line.

During the first half of 1963, improvements in the German trade balance, long-term financial inflows, and relatively tight monetary policy resulted in almost continuous buying pressure on the mark. Between early April and the end of July 1963, the Bundesbank and the Federal Reserve Bank of New York undertook fairly heavy coordinated interventions to stem the mark's appreciation. This time the Federal Reserve financed nearly all of its interventions from two swap drawings. In August, buying pressure on the German mark eased somewhat along with conditions in the German money market, but with the mark often trading above par, the Federal Reserve System was unable to acquire enough German marks from the market to fully 


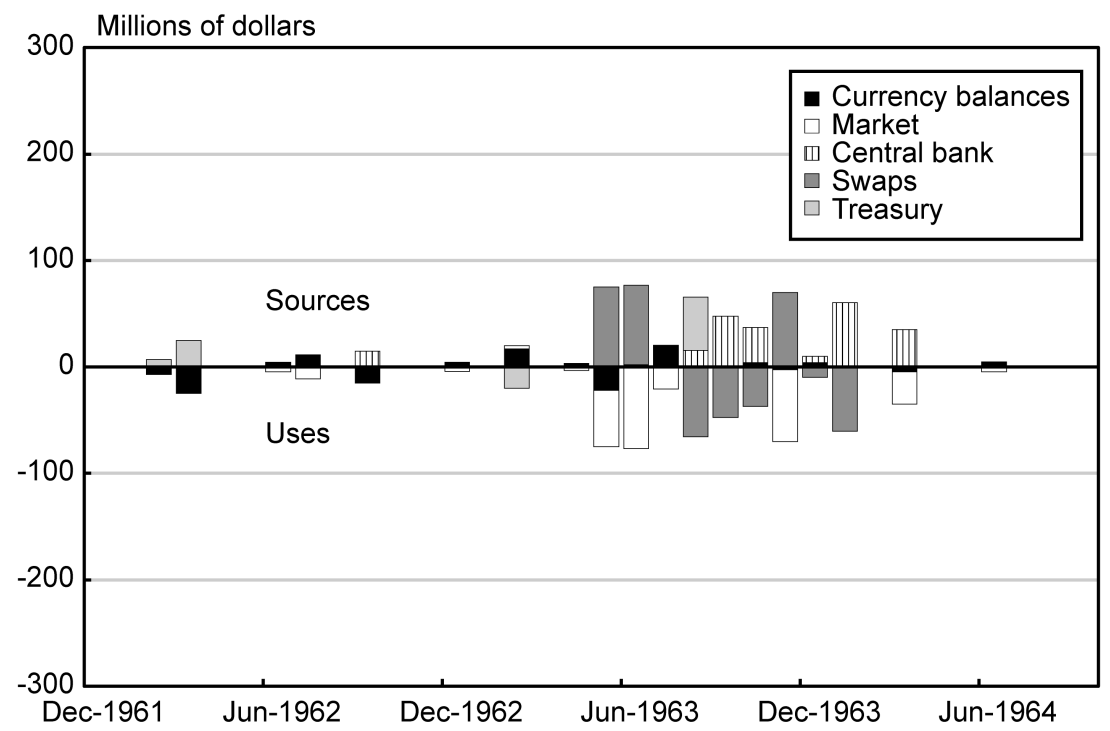

Fig. 4.21 Federal Reserve sources and uses of German marks, December 1961-September 1964

Notes: "Central bank" contains "exceptional items." Data do not include unexplained items or profits. Data are from the Federal Reserve System.

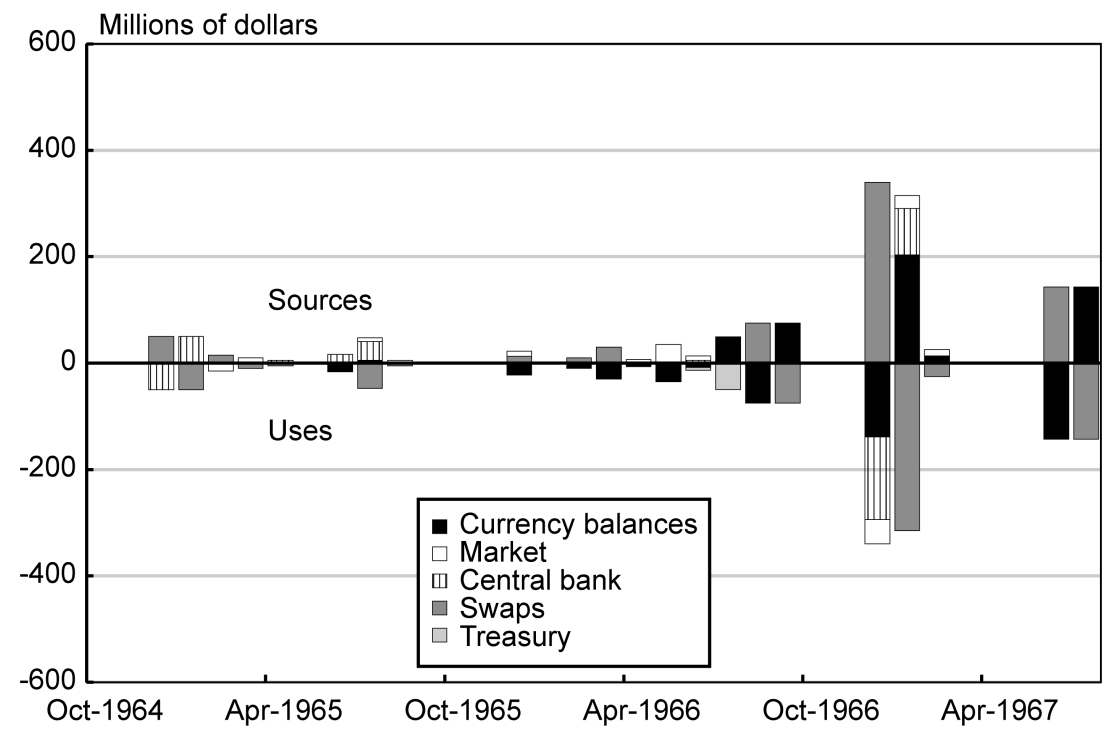

Fig. 4.22 Federal Reserve sources and uses of German marks, October 1964July 1967

Notes: "Central bank" contains "exceptional items." Data do not include unexplained items or profits. Data are from the Federal Reserve System. 


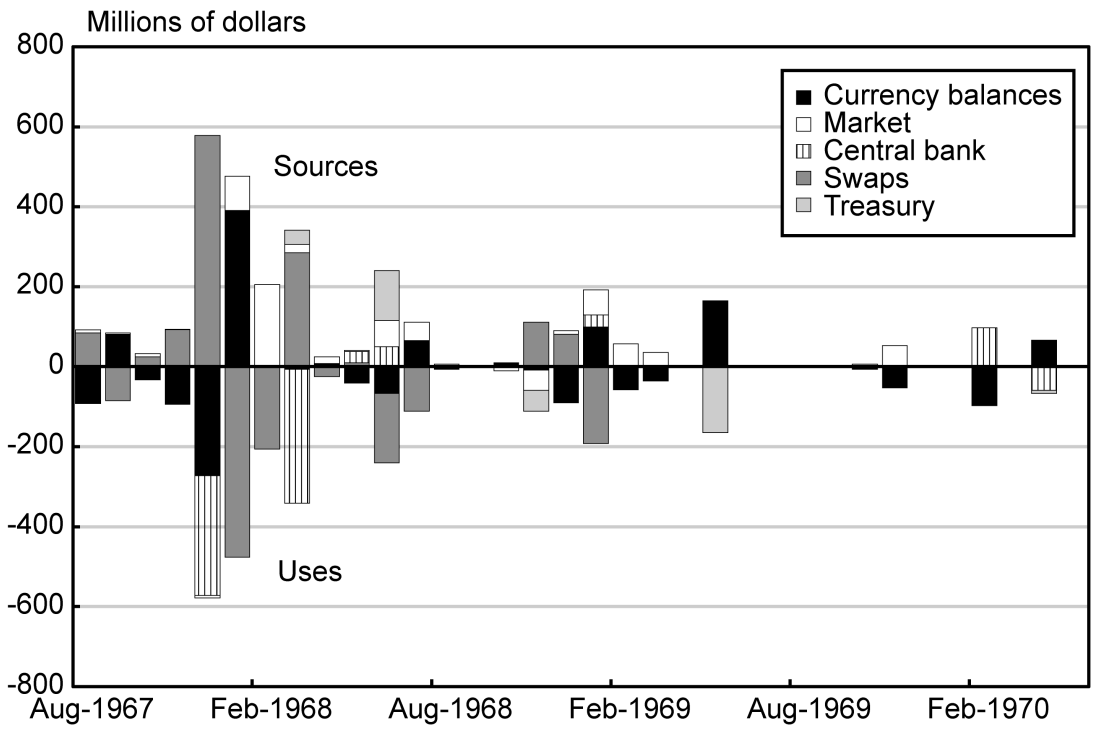

Fig. 4.23 Federal Reserve sources and uses of German marks, August 1967May 1970

Notes: "Central bank" contains "exceptional items." Data do not include unexplained items or profits. Data are from the Federal Reserve System.

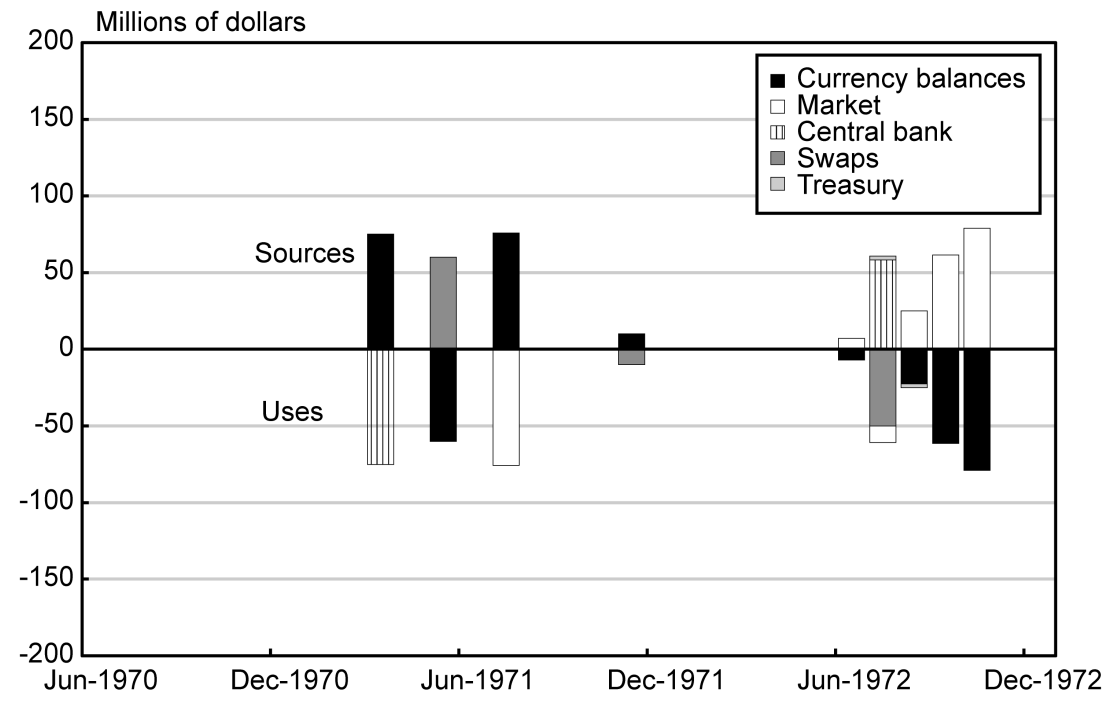

Fig. 4.24 Federal Reserve sources and uses of German marks, June 1970-December 1972

Notes: "Central bank" contains "exceptional items." Data do not include unexplained items or profits. Data are from the Federal Reserve System. 


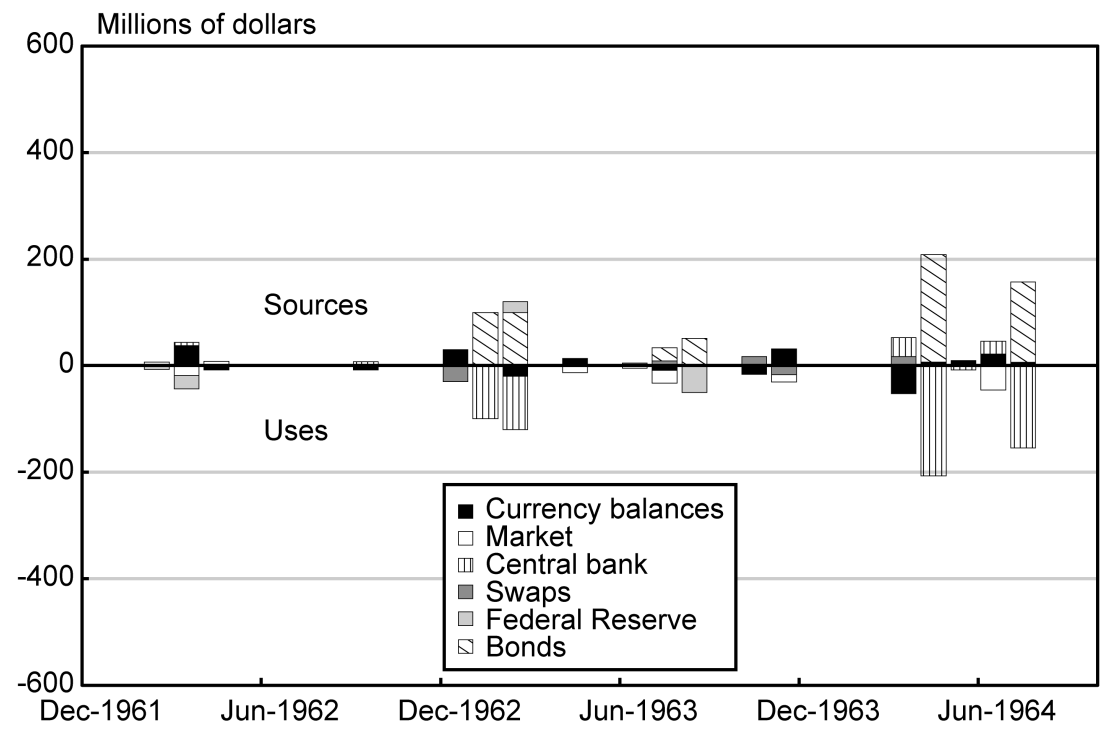

Fig. 4.25 US Treasury sources and uses of German marks, December 1961-September 1964

Notes: "Central bank" contains "exceptional items." Data do not include unexplained items or profits. Data are from the Federal Reserve System.

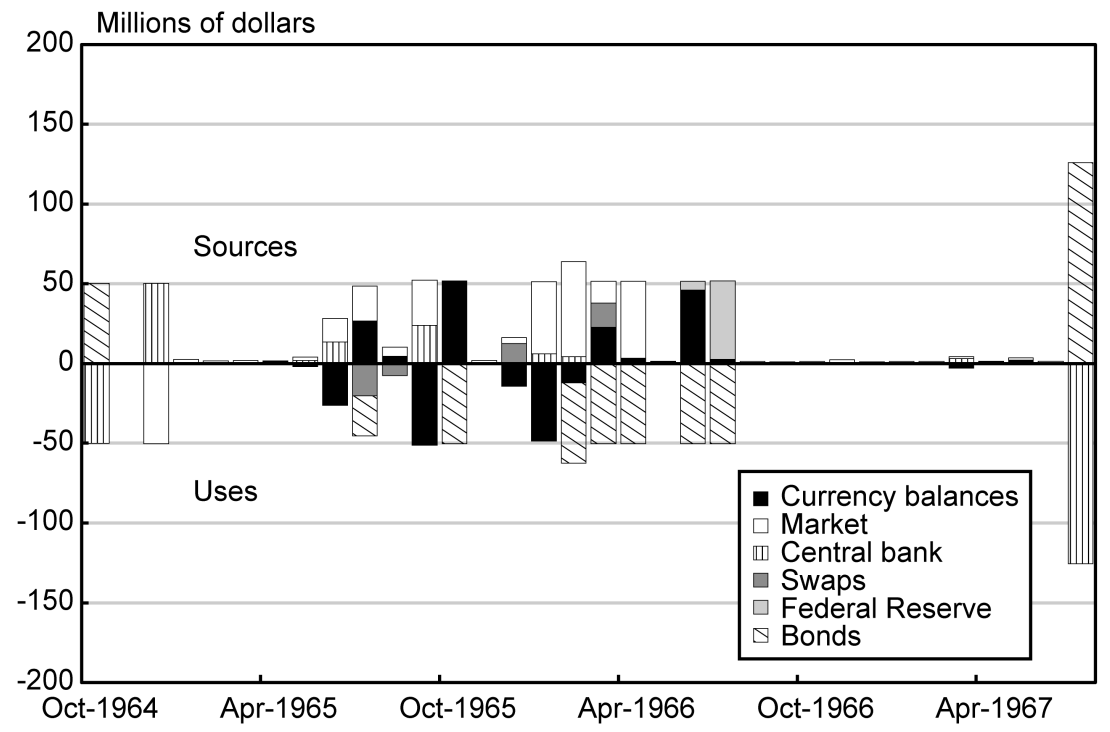

Fig. 4.26 US Treasury sources and uses of German marks, October 1964July 1967

Notes: "Central bank" contains "exceptional items." Data do not include unexplained items or profits. Data are from the Federal Reserve System. 


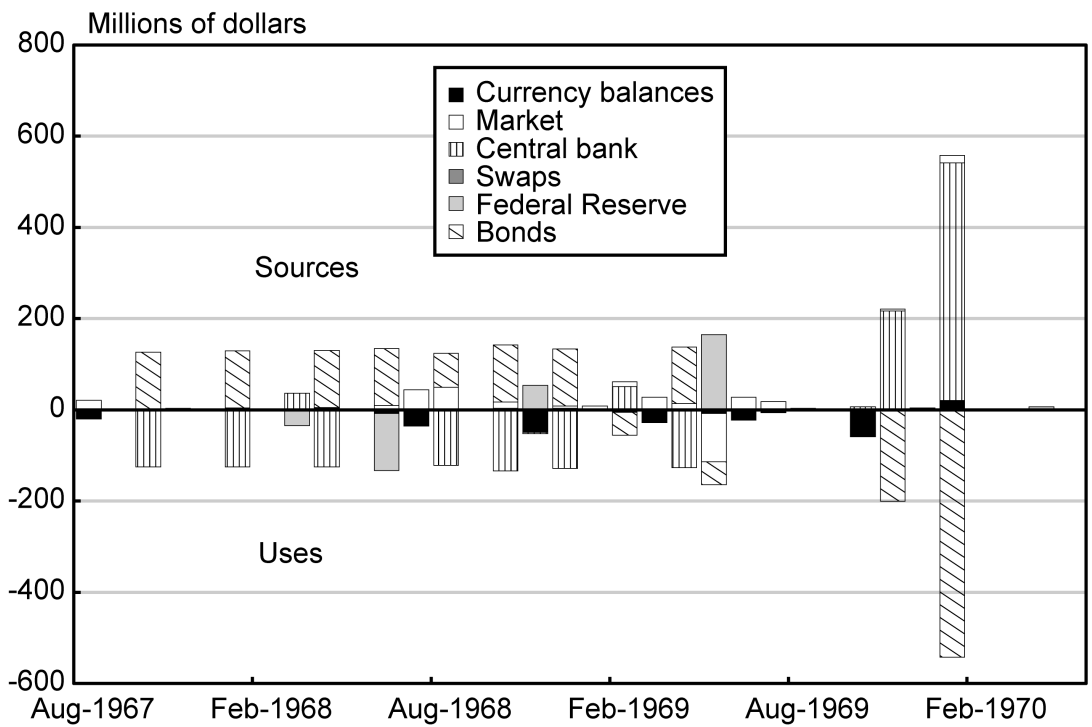

Fig. 4.27 US Treasury sources and uses of German marks, August 1967May 1970

Notes: "Central bank" contains "exceptional items." Data do not include unexplained items or profits. Data are from the Federal Reserve System.

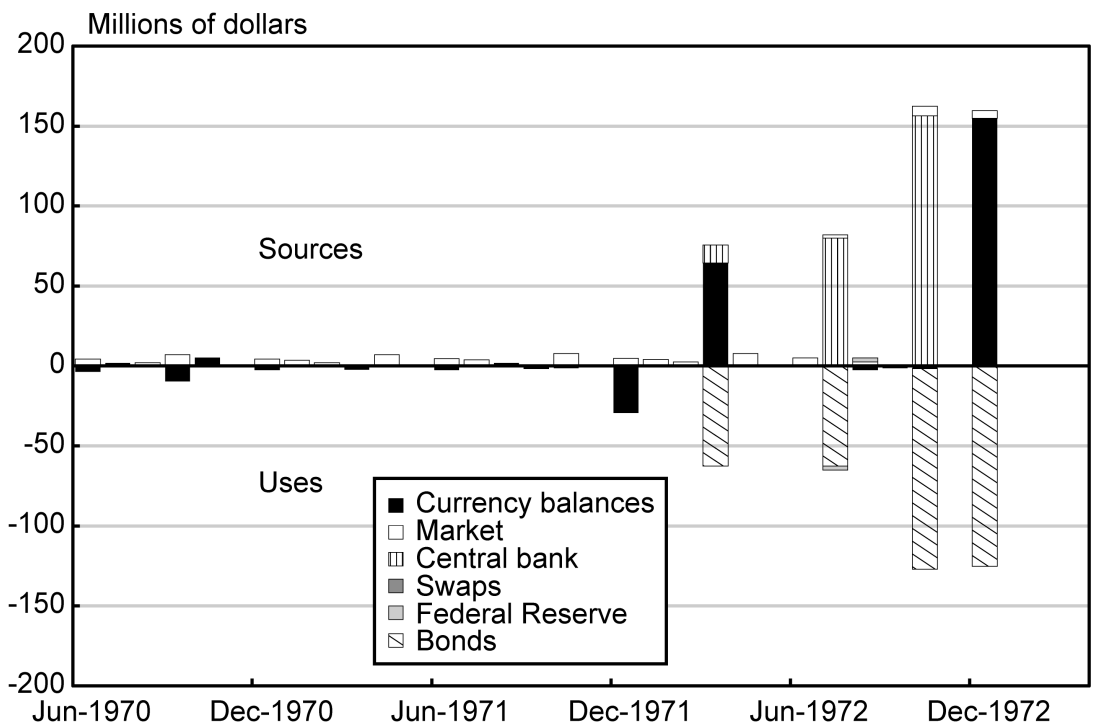

Fig. 4.28 US Treasury sources and uses of German marks, June 1970-May 1972

Notes: "Central bank" contains "exceptional items." Data do not include unexplained items or profits. Data are from the Federal Reserve System. 
repay its swap drawing. The Bundesbank offered to extend the swap line, but the Federal Reserve instead turned to the US Treasury. The Treasury issued $\$ 50$ million worth of two-year, mark-denominated bonds (Roosa bonds) to the Bundesbank and sold the proceeds to the Federal Reserve System. This was the first time that the Treasury backstopped a central bank swap by issuing Roosa bonds. Over the next three months, when pressure on the mark eased, the Federal Reserve purchased marks off-market from central banks and from the German Defense Ministry, which needed dollars to buy US military equipment (Bulletin, March 1964, 297). On 10 October 1963, with recent swap debt repaid, the Federal Reserve System increased its swap line with the Bundesbank to $\$ 250$ million.

In late 1963, short-term funds moved back into German marks, prompting the Federal Reserve to draw $\$ 70$ million equivalent marks from its swap line with the Bundesbank. The Federal Reserve used part of these funds to intervene with the US Treasury in the New York market, but in contrast to earlier episodes, the Federal Reserve also used a portion of the proceeds from the swap drawing to cover excess dollar balances at the Bundesbank. Over 1963, foreign-exchange reserves in Germany - presumably all dollars - had increased substantially. In January 1964, the German government, which needed additional dollars for military expenditures, supplied the Federal Reserve with marks to repay its swap drawing in full by early 1964 .

In response to rumors of a mark revaluation, the Treasury - in concert with the Bundesbank - sold \$21 million equivalent marks three months forward. This was the Treasury's first outright forward sale since 1961. On 23 March 1964, Germany imposed a 25 percent withholding tax on nonresidents' interest income from German fixed-interest securities (Bulletin, September 1964, 1124). The tax reduced long-term financial inflows and induced some liquidation of investments in German bonds. In addition, the Bundesbank undertook market swaps with German commercial banks (selling dollars spot and repurchasing them forward for delivery in 90 to 180 days) at preferential rates hoping to encourage these banks to purchase US Treasury securities - a financial outflow. Such market swaps would eventually create a problem for the Bundesbank, because the commercial banks would simply sell the dollars thus acquired back into the market. The Federal Reserve used the respite that controls afforded to buy marks and repay the swap drawings made early in March.

Although pressure on the mark-dollar rate had subsided, the US Treasury sold $\$ 200$ million worth of mark-denominated bonds to the Bundesbank in April 1964 and used the proceeds to again buy excess dollar balances from the Bundesbank. ${ }^{78}$ The excess dollars resulted from financial flows out of Italy and into Germany. The Bank of Italy required dollar reserves for support of the lira, so the US Treasury repaid a \$200 million equivalent lira bond that it had issued in 1962 to the Bank of Italy. To do so, the Treasury purchased lira from the Bank of Italy with the dollars it acquired selling the 
bonds to the Bundesbank. In the end, the Treasury financed a lira support operation with debt issued to the Bundesbank.

The mark came under renewed upward pressure in mid-1964, and by the end of the year, US Treasury had $\$ 678$ million equivalent in markdenominated bonds outstanding. In December 1964, the Federal Reserve also drew $\$ 50$ million worth of marks on the swap line to absorb dollar balances at the Bundesbank. Germany's need for dollars to finance military purchases again enabled the Federal Reserve to reverse this swap in January 1965.

From May 1965 through October 1965, Germany's trade balance deteriorated and the mark began to trade below its parity. With pressure off of the German mark, the Federal Reserve System and the US Treasury purchased German marks from central banks and from the market in order to strengthen their reserve positions and to pay down US Treasury markdenominated bonds. This was the first liquidation of the bonds since the Treasury issued them in 1963, but at the end of 1965, the Treasury still had a total of $\$ 602$ million worth of mark-denominated bonds outstanding.

The German balance-of-payments deficit that emerged in 1965 continued through the first five months of 1966, now largely because higher Eurodollar rates attracted a short-term financial outflow from Germany. The mark generally traded below par; the Bundesbank intervened substantially, and Germany's foreign-exchange balances declined. The Treasury took this opportunity to reduce its mark indebtedness further, in part, with the Federal Reserve's help. The Federal Reserve purchased marks from the market and European central banks between April and June and sold them to the US Treasury.

In May 1966, the Bundesbank raised its discount rate (Bulletin, September 1966, 1322). This hike, in conjunction with the renewed wave of sterling selling, produced a financial flow into German marks that returned the spot rate to parity and resulted in the Bundesbank acquiring more reserves than it previously had lost. Eventually, the Bundesbank cut its reserve requirements, but it continued to acquire dollar reserves.

Again, the Federal Reserve used its own balances and drew on its swap line to purchase dollars from the Bundesbank. The Federal Reserve also sold marks outright and undertook swap transactions with the market involving a spot sale of German marks and a forward purchase. The Treasury, which was intent on trying to pay down outstanding mark obligations, did not participate in these interventions.

In early 1967, as the mark once again eased, the Federal Reserve easily repaid its swap drawings. The Federal Reserve then bought marks as a precaution. In November 1967, the market became unsettled following the depreciation of the pound and rumors of a mark appreciation. Demand for German marks increased. The Bundesbank acquired \$357 million outright in the spot market (Bulletin, March 1968, 277-78). The Bundesbank then undertook market swaps, selling dollars spot against forward purchases with 
German commercial banks to keep dollars in the market and to reduce a widening premium on forward marks. By 30 November 1967, the Bundesbank had outstanding market swaps totaling \$600 million (Bulletin, March 1968, 278). The Federal Reserve increased its swap line with the Bundesbank from $\$ 400$ million to $\$ 750$ million. The Federal Reserve then drew $\$ 300$ million equivalent marks on that line and sold them to the Bundesbank for dollars. This official swap transaction provided the Bundesbank with cover for one-half of its outstanding swap commitments with German commercial banks (Bulletin, March 1968, 278). In addition, as uncertainty about the official gold prices grew, the Federal Reserve sold \$7.3 million worth of marks in the New York market. Late in December 1967, when dollars briefly flowed out of Germany, the Federal Reserve bought marks.

After the closing of the Gold Pool in March 1968, speculative financial flows into Germany increased and the Bundesbank quickly acquired $\$ 800$ million. The Bundesbank immediately offered most of these dollars to commercial banks on an attractive swap basis. This swap offering was intended to provide dollar liquidity to the Eurodollar market, lower Eurodollar interest rates, and thereby to take pressure off of the British pound. The Federal Reserve absorbed $\$ 300$ million through its swap line, thereby providing some cover for the forward leg of Bundesbank's swap transactions (Bulletin, September 1968, 731).

In May 1968, Bundesbank President Karl Blessing reiterated Germany's intention not to convert dollars into gold. That same month, as unrest was erupting in France, the German mark came under downward pressure following an April increase in the Federal Reserve's discount rate. At the time, the Bundesbank had announced an easing in German monetary policy. The Federal Reserve again used the opportunity afforded by the financial outflow from Germany to buy marks in the New York market and to repay its outstanding mark obligations. In May 1968, the Federal Reserve also purchased \$25.2 million worth of marks from Canada, which had recently floated a bond in Germany, and in June the Federal Reserve acquired \$50 million equivalent marks from the Bundesbank when the latter sought to replenish dollar reserves following a sale of dollars to France. In late June, the central bank acquired an additional $\$ 125$ million equivalent marks from the US Treasury, which had just issued special mark-denominated securities to German banks as part of an agreement with Germany to absorb dollars associated with stationing troops there (Bulletin, September 1968, 732). By the end of August 1968, these mark acquisitions enabled the Federal Reserve to repay all of its swap obligations to the Bundesbank and to the BIS. In that same month, the Treasury issued the first of a new series of mark-denominated securities to the Bundesbank, which were designed to absorb troop dollars, in addition to the securities already issued to German commercial banks. By year's end, the Treasury had $\$ 1.3$ billion equivalent mark-denominated securities outstanding. 
In late August 1968, however, rumors of a mark revaluation resurfaced. After permitting an unprecedented one-day appreciation of the mark to its ceiling, the Bundesbank acquired \$820 million as the Labor Day weekend approached, with half of that amount coming on Friday alone (Desk Report 1969, 34). Between August 27 and September 6 the Bundesbank purchased $\$ 1.6$ billion (Bulletin, March 1969, 214). The Bundesbank also undertook market swaps to encourage German commercial banks to hold dollars. In cooperation with the Bundesbank, the Federal Reserve and the US Treasury each sold $\$ 17$ million equivalent German marks forward in the New York market during August and early September, but despite the concerted actions to limit speculation, the Bundesbank acquired an additional $\$ 840$ million in the three days ending 6 September 1968.

Speculation dramatically intensified in November, after a brief respite in October. At the Basle Meeting, the central bank governors recommended a 7.5 percent revaluation of the mark (Solomon 1982, 2). Instead the Bundesbank intensified its intervention efforts, making very large dollar purchases (over $\$ 1$ billion in just two days ending Friday, 15 November 1968, and \$2 billion since the beginning of the month) and undertaking approximately $\$ 1$ billion in swaps with German commercial banks (Desk Report 1969, 37; Bulletin, March 1969, 215). Rather than invest the swap proceeds in interestearning assets, however, these commercial banks resold the now-covered dollars in the market, thereby negating the effects of the swap and leaving the Bundesbank with a forward obligation to sell marks. The Bundesbank responded by issuing swaps only to banks that used the proceeds to acquire US Treasury securities, but it soon had to sell marks through outright forwards (Bulletin, March 1969, 215-16). German banks wanted outright cover for their dollar position; they did not want cover on a swap basis which eventually had to be rolled over, and therefore left them with some exposure. Bundesbank forward mark sales in late November amounted to \$246 million equivalent (Bulletin, March 1969, 216). The Federal Reserve drew $\$ 111.3$ million equivalent marks on its swap line with the Bundesbank and sold $\$ 47$ million equivalent marks spot in New York. With the remaining marks from the swap drawing as partial cover, the Federal Reserve also sold $\$ 72$ million equivalent marks forward in New York. In December, as the mark temporarily weakened, the Federal Reserve bought marks spot as additional cover for its forward position.

After acquiring $\$ 850$ million over two days -18 and 19 November 1968 - the German authorities announced that they would not revalue the mark. ${ }^{79}$ They then undertook a faux revaluation by adjusting value-added tax rates to raise export prices and lower import prices (Solomon 1982, 158). In addition, the Bundesbank imposed 100 percent reserve requirements on new foreign-owned mark deposits at German banks, reinforcing the previous ban against interest payments on such deposits (Bulletin, March 1969, 216). 
These policies were sufficient to encourage a financial outflow by the end of November 1968, enabling the Federal Reserve to acquire, once again, sufficient marks to repay its swap drawings by January $1969 .{ }^{80}$ Nevertheless, in 1968, Germany had acquired a little more than \$1billion in foreign exchange reserves. In January, as the mark moved below par, the Bundesbank sold large amounts of dollars in the market and reduced the attractiveness of its swaps with commercial banks. The larger sales of dollars continued in February and March 1968. United States monetary authorities made heavy market purchases of German marks between December 1968 and March 1969. In addition to paying down its swap drawings, the Federal Reserve used the newly acquired marks to meet forward obligations as they matured, and to increase balances. In February 1969, the Treasury, which also had been acquiring small amounts of marks from the market and from the Bundesbank, redeemed a $\$ 50$ million equivalent outstanding mark-denominated note.

The outflow of funds from Germany reversed itself in April 1969, when President de Gaulle's resignation heightened speculation of a French franc devaluation. Concurrent rumors that some members of the German cabinet favored an 8 to 10 percent mark revaluation as part of a multilateral exchange rate readjustment encouraged speculative flows into marks (Desk Report 1970, 9). Moreover, a tightening of monetary and fiscal policies to combat growing inflationary forces only worsened Germany's balanceof-payments situation (Desk Report 1970, 9-10).

Speculative flows became massive, so much so that in the three days prior to Friday, 2 May 1969, the Bundesbank acquired $\$ 860$ million (Bulletin, September 1969, 702). On 7 May, the Bundesbank discontinued its swap operations, since commercial banks were now placing the funds into the Eurodollar market where they were recycled into the foreign exchange market and again converted into marks. On 8 May, the Bundesbank received very heavy inflows of dollars, much of it through support operations in the New York market. The Bundesbank then limited such support operations to only 400 million German marks, an amount that quickly proved inadequate. Although IMF rules oblige a country to defend its currency in its own market, a member country was not obliged to defend its currency in a foreign market. To assist in the defense of the mark, the US Treasury sold $\$ 106$ million worth of marks into the New York market. It financed this defensive operation by acquiring virtually all ( $\$ 165$ million equivalent) of the Federal Reserve's mark balances. The following day, speculation was equally intense, "the heaviest flow in international financial history" (Bulletin, September 1969, 703).

"The speculative onslaught between the end of April and May 9 increased German monetary [international] reserves by some $\$ 4.1$ billion-including $\$ 2.5$ billion on 8 and 9 May alone-to a record level of $\$ 12.4$ billion" (Bulletin, September 1969, 703). After Germany emphatically dismissed revalu- 
ation rumors, speculation subsided. With inflationary pressures now emerging, Germany tightened fiscal and monetary policies. Absorbing domestic liquidity in this situation, however, could only encourage additional inflows. Revaluation now seemed a certainty; only the timing remained unclear.

Speculation intensified again as the 28 September election approached. The Bundesbank acquired increasing amounts of dollars, but was simultaneously selling dollars on a swap basis. The funds were spilling into the Eurodollar market. "[O]n September 18, after such sales had reached \$0.7 billion over a 10-day period, the [Bundesbank] raised its swap rate, thus bringing to a virtual halt the covered movements of German funds into the Euro-dollar market" (Bulletin, March 1970, 230). A further tightening of monetary policy in mid-September only intensified the financial inflows. The government closed the foreign exchange market for the two days prior to the elections and suspended official foreign-exchange operations. In New York, the mark traded above parity. When the election was inconclusive, the Bundesbank briefly returned to the market, took in \$245 million in the first hour and a half of trading, and then allowed the mark to float. The mark appreciated $71 / 4$ percent by mid-October, with the Bundesbank gradually raising its buying rate to keep a floor just below the market rate (Desk Report 1970, 20). The Federal Reserve also bought marks. The coalition government that took office on 21 October 1969 revalued the mark 9.3 percent on 24 October 1969 and eliminated the special taxes on exports and imports that created the faux revaluation of November 1968. "The revaluation was larger than had generally been anticipated, thus decisively removing the mark from the realm of speculation" (Bulletin, March 1970, 231).

The revaluation led to a severe outflow of funds from Germany, which depleted official reserves and drained liquidity. To stem the movement out of marks, the Bundesbank eliminated discriminatory reserve requirements on foreign deposits. The bank also raised its Lombard rate, and in December 1969, German authorities removed the prohibition on paying interest of foreign-owned deposits. The Federal Reserve took advantage of the financial outflows to rebuild its depleted mark balances. The US Treasury activated revaluation clauses covering its mark-denominated securities. This allowed the Treasury to purchase marks at a substantial discount either to hold as cover or to resell for a substantial profit. By now, the Bundesbank had depleted most of its liquid dollar holdings. To recoup these, Germany sold mark-denominated US Treasury securities back to the Treasury for dollars, sold $\$ 500$ million in gold to the US Treasury, and drew $\$ 1.1$ billion in credits from the IMF (Bulletin, March 1970, 232).

\subsection{Breakdown of Bretton Woods, 1970-1973}

Much of the exchange-market turmoil from 1967 through 1969 stemmed from the adjustment problems of individual currencies. ${ }^{81}$ While these raised uncertainties about the underlying Bretton Woods parity structure and 
created undesirable reshufflings of dollar reserves, they did not directly reflect problems with the dollar. Inflation in the United States, however, was accelerating, and the nature of the international financial problem was changing. By 1970, the market viewed exchange-market disorder as a dollar crisis and not, as was the case earlier, a problem of unsustainable cross rates (Solomon 1982, 182).

According to Coombs (1976, 204-11), the Nixon administration, which came to office in January 1969, believed that our major trading partners were deliberately discriminating against the United States. Consequently, the administration adopted a practice of "benign neglect" about the growing balance-of-payments deficit and the United States' commitments under Bretton Woods. A subsequent US focus on domestic growth and employment and the emergence of inflation flooded foreign economies with dollar reserves, put upward pressures on their currencies and price levels, and ultimately led to the demise of the Bretton Woods system.

\subsubsection{Closing the Gold Window, 1970-1971}

Despite some tightening in US monetary policy, the US inflation rate continued to accelerate through 1969, reaching nearly 6 percent by year's end. The onset of a recession induced the Federal Reserve to again loosen monetary policy and to maintain an accommodative stance in 1970 and 1971 (figure 4.6). Interest rates in the United States fell, and as US banks repaid earlier borrowings from foreign affiliates, so did Eurodollar rates. Many European countries, however, were tightening monetary policy to ward off inflationary pressures by 1969. Even when European countries lowered interest rates, as they eventually had to do, their movements typically lagged those in the United States during this period. This interest-rate pattern induced heavy financial flows out of dollar-denominated assets. Initially, much of the dollar reflow went to countries like the United Kingdom and France that needed to rebuild dollar reserves and to repay debts (Bulletin, September 1971, 783). The dollar reflows, however, quickly became a problem for countries like Germany, Italy, Belgium, the Netherlands, and Switzerland. Dollar inflows pushed their currencies to their upper parity limits vis-à-vis the dollar, forcing their central banks to intervene. In many cases, the acquisition of dollar reserves offset domestic monetary restraint programs designed to reduce inflationary pressures. Attempts to tighten policy further only aggravated the inflow of funds. By early 1971, as Coombs $(1976,212)$ notes, the process developed a self-reinforcing aspect as "overt speculation further swelled the torrent of dollars flowing to foreign markets."

By the summer of 1971, confidence in US monetary policy was rapidly evaporating and a crisis atmosphere was emerging. Inflation in the United States remained around 4.4 percent, despite slow economic growth and a high unemployment rate. Moreover, the US balance-of-payments position continued to deteriorate. Expecting further revaluations, speculators began borrowing Eurodollar funds to buy foreign currencies (Bulletin, September 
1971, 812). On 6 August 1971, a congressional subcommittee identified the dollar as overvalued and called for a realignment of currency rates, including a dollar devaluation. On that same day, the US Treasury reported a loss of gold and reserves of $\$ 1$ billion, largely as Britain and France exchanged dollars to repay IMF debts. Over the next week, $\$ 3.7$ billion in gold and reserve assets moved abroad (Coombs 1976, 215). Gold moved to $\$ 44$ per ounce in London, and speculative flows out of dollars and into foreign central banks intensified. On 15 August 1971, President Nixon closed the gold window; that is, he suspended convertibility of officially held dollars into gold. Acting under the Economic Stabilization Act of 1970, he ordered a ninety-day freeze on wages and prices and recommended new tax measures to stimulate investment and employment. He also introduced a temporary 10 percent surcharge on dutiable imports.

Although Chairman Burns told the FOMC that suspending the dollar's convertibility would be temporary, Charles Coombs appreciated the action's real significance: "[T]he decision to close the gold window had demolished with one stroke the Bretton Woods exchange rate system" (FOMC Memoranda, 24 August 1971, 27). The announcement surprised the major European governments, who closed their exchange markets and sought - unsuccessfully - a joint policy response to the US measures (Bulletin, September 1971, 786). They reopened their markets on Monday, 23 August, and although they formally adhered to their parities - with the exception of France - they suspended their commitments to defend them. Japan had initially attempted to defend its parity, and took in \$2 billion on 15 August 1971 alone. With substantial inflows of dollars continuing, Japan suspended its official intervention on 28 August. All of the major currencies appreciated against the dollar during the next two months - except the fixed French commercial franc - as speculative flows continued. At the high end was the German mark, which rose 9.5 percent above its previous ceiling. At the low end was the French financial franc, which rose only 1.7 percent (Bulletin, September 1971, 786)..$^{82}$

The foreign currencies appreciated despite heavy foreign interventions, and foreign central banks continued to accumulate large amounts of unwanted dollar reserves, which contributed to their inflationary pressures. As a consequence, monetary authorities began to tighten controls on financial inflows. "The exchange rate structure thus emerging after August 15 was, in most instances, the product of controlled rather than free floating" (Bulletin, October 1971, 786). Europeans and Latin American countries argued that the US import surcharge was also distorting exchange-rate relationships (Solomon 1982, 189). They lodged a formal complaint with the General Agreement on Tariffs and Trade (GATT).

In 1971 prior to the closing of the gold window, the Federal Reserve frequently initiated large swap drawings to forestall foreign central banks from converting excessive dollars reserves into US monetary gold. On 1 January 
1971, the Federal Reserve had outstanding swap commitments of \$810 million. By July 1971, the Federal Reserve had reduced this to $\$ 605$ million often with the aid of US Treasury sales of gold and SDRs, borrowings from the IMF, and the issuance of foreign-currency denominated securities. As funds moved rapidly abroad, the Federal Reserve then drew $\$ 2.2$ billion on its swap lines - with assurances of a Treasury backstop - to provide further cover to central bank through 13 August 1971 (Coombs 1976, 217; Bulletin, September 1971, 787).

After 13 August 1971, the Federal Reserve made no further drawings on its swap lines. The Federal Reserve encountered difficulties in repaying outstanding swaps because most foreign central banks did not want the Federal Reserve buying their appreciating currencies in the market. They preferred to roll over existing swaps, expecting that new parities would soon be established and a reversal of financial flows would follow (FOMC Memoranda, 16 November 1971, 15; Bulletin, September 1971, 787). In contrast, the Belgian National Bank asked the Federal Reserve to repay a \$35 million swap drawing that had been outstanding for seven months. This required the Federal Reserve to purchase Belgian francs at a premium and to incur an overall loss of $\$ 1.9$ million on the transaction. The US Treasury preferred that the Federal Reserve take a loss on this transaction to financing the repayment through official reserves (FOMC Memoranda, 19 October 1971, 18). By 14 October 1971, the Federal Reserve had outstanding swap commitments of $\$ 3.0$ billion.

Despite this heavy use of swaps, the United States lost large amounts of official reserves to foreign central banks in 1971. "From January 1, through mid-August a total of $\$ 3.1$ billion in such assets was paid out, including $\$ 864$ million of gold, $\$ 394$ million of foreign exchange, $\$ 480$ million of SDRs, and $\$ 1,362$ million taken down against the US IMF position" (Bulletin, September 1971, 789). In addition, the Treasury issued $\$ 582.7$ million in new Swiss franc denominated securities between 1 January 1971 and 13 October 1971 (Bulletin, September 1971, 789).

\subsubsection{First to Float: Canada}

In stark contrast to most other key developed countries after the Second World War, Canada had allowed its currency to float freely against the dollar from September 1950 until May 1961 (see Bordo, Dib, and Schembri 2010). Rather than import inflation from the United States, Canada again floated in 1970. Its actions set a precedent for both other countries and speculators.

Following the devaluation of sterling in November 1967, the Canadian dollar came under heavy speculative attack. The market also feared that the recently announced US restraints on financial flows might adversely affect US direct investments into Canada and short-term financial flows between the two countries (Bulletin, August 1968, 739). Canadian reserve losses were heavy in January and February 1968, causing Canadian mone- 
tary authorities to draw $\$ 250$ million on the $\$ 750$ million swap facility with the Federal Reserve and \$426 million from the IMF (Bulletin, August 1968, 740). The Bank of Canada also increased its discount rate.

Pressures on the Canadian dollar persisted and intensified in March 1968, as speculative funds moved out of Canadian dollars and into gold. Canada sought and received additional international credits amounting to $\$ 900$ million from the US Export-Import Bank, the German Bundesbank, the Bank of Italy, and the Bank for International Settlements. These credits did not include the $\$ 500$ million still available to Canada through the Federal Reserve swap line, which the central bank subsequently increased to $\$ 1.0$ billion (Bulletin, August 1968, 740). In addition, the United States exempted Canada completely from the financial restraints that it imposed in January 1968. For its part, Canada agreed to invest its dollar reserves - apart from working balances - in US government securities (Bulletin, August 1968, 740). Canada again raised its bank lending rate when the Federal Reserve Bank hiked the discount rate.

The situation briefly improved in the spring of 1968, enabling Canada to acquire reserves and repay international credits. In 1969, however, the United States tightened monetary policy. High interest rates in the United States and in the Eurodollar market encouraged a financial outflow from Canada and prompted the Bank of Canada to tighten its monetary policy and its restrictions on financial outflows.

With the onset of a recession in early1970, the United States eased monetary policy, and the financial tide quickly reversed. Strong inflows of both long-term and short-term funds now pushed the Canadian dollar to the top of its trading range. The Bank of Canada-as agent for the federal government - bought large amounts of US dollars to keep the Canadian dollar within its parity range, adding unwanted domestic liquidity to the Canadian market at a time when the Bank of Canada was trying to contain inflationary pressures. Inflation was currently running at approximately 4 to 5 percent and wage settlements reached 9.1 percent (Powell 2005, 71, fn. 90). Although the Bank of Canada favored a new par value with wider parity bands, the government rejected the idea out of a concern that it would provide only temporary relief and would not be credible. The government also considered asking the United States to rescind its Canadian exemption under the US Interest Equalization Tax, but the exemption helped reduce the borrowing costs of provincial governments (Powell 2005, 72).

On Sunday, 31 May 1970, Finance Minister Benson announced that the Bank of Canada would no longer defend the upper limit for the Canadian dollar, effectively allowing it to appreciate. Benson intended to refix the exchange rate as soon as possible. The Bank of Canada intervened on 1 June when the Canadian market opened to smooth the increase in the rate. Over the following weeks, the Bank of Canada intervened to dampen the swings, especially excessive increases in the exchange rate (Bulletin, September 1970, 695). The Canadian dollar, however, was now floating. 
Coombs viewed the Canadian float as a serious threat to the Bretton Woods system. He noted that the ability of central banks to defend their parities against speculative attacks was increasingly "suspect." Nevertheless, "[u]ntil the Canadian decision to let their rate float, the market had not taken seriously official discussions of rate flexibility." (FOMC Memoranda, 23 June 1970,42) Reflecting his overall attitude toward floating rates, Coombs viewed financial flows under the Canadian float as destabilizing:

... the rise in the rate tended to be self-reinforcing in that it encouraged an increasing tendency to cover Canadian dollar commitments. Another factor in the market, starting toward the end of July, was the appearance of professional traders, mainly European banks, who would move in and out of the Canadian dollar within a single day to take advantage of the wide fluctuations in the rate, their actions clearly aggravating those fluctuations. (Bulletin, September 1970, 695)

This early float, however, insulated the Canadian dollar from much of the exchange-market chaos of 1971.

\subsubsection{The German Mark Example}

Germany's experience in 1970 and 1971 provides the clearest example of the problem with fixed exchange rates when domestic and international objectives conflict. ${ }^{83}$ In the spring of 1970 , the Bundesbank began to tighten monetary policy to counteract growing inflationary pressures. Germany's GNP deflator increased 7.3 percent in 1970 and 7.7 percent in 1971 (IMF 1972, 7). With interest rates on dollar-denominated assets falling - the United States experienced a recession in 1970 - funds began to flow into Germany. The mark, which had been trading near its floor value ever since the October 1969 revaluation, began to rise sharply. By mid-May 1970 with the mark now trading at its upper limit, the Bundesbank began acquiring substantial amounts of dollars through its interventions. The floating of the Canadian dollar in June 1970 only added to speculative pressures against the mark. On 10 June 1970, the Bundesbank, in "the most hectic day of trading since the fall of 1969," purchased $\$ 640$ million at the upper parity band, but the rate moved even higher that afternoon in New York after the close of business in Frankfurt (Bulletin, September 1970, 697). During the whole of the second quarter of 1970, the Bundesbank acquired \$1.4 billion in reserves (Bulletin, March 1971, 189-207).

Germany next attempted to fine-tune its monetary policy and to supplement it with other measures, like a tighter fiscal policy. The Bundesbank cut its discount and Lombard rates hoping to take pressure off market rates, but the bank also instituted heavy reserve requirements on bank liabilities. Although short-term rates fell briefly, they quickly turned around. The net effect was that inflows of reserves continued and in the third quarter of 1970, the Bundesbank acquired almost \$2.5 billion (Bulletin, March 1971, 198). In late October 1970, the Bundesbank converted its reserve requirements into 
a form of capital controls by directing them to certain interest-arbitrage transactions and to dealings related to foreign borrowing. Continued pressure on the mark, however, forced the Bundesbank to lower its discount and Lombard rates again in early November 1970. Despite these maneuvers, funds continued to flow into Germany. In December, following a cut in the US discount rate, the Bundesbank again lowered its official lending rates, and German interest rates fell more closely in line with Eurodollar interest rates. Nevertheless, in the fourth quarter of 1970, the Bundesbank acquired $\$ 2.3$ billion in reserves, and remained hampered in adopting an anti-inflation policy stance.

Despite these interest-rate cuts, the spread vis-à-vis Eurodollar rates continued to attract funds into Germany during early 1971. The spot rate remained at, or near, the upper parity band and the Bundesbank continued to acquire dollars. "During the period February-April 1971, German corporate borrowing abroad amounted to roughly $\$ 2.5$ billion, nearly equivalent to total business lending by the entire German banking system over the same period" (Bulletin, October1971, 784). In February and March 1971, the Bundesbank undertook a series of forward German mark sales through the Federal Reserve Bank of New York in an effort to offset the attractive interest-rate differential on marks and forced the mark to a substantial forward discount. The sales failed to stop the dollar inflow, however, and in mid-March 1971, after $\$ 537$ million worth of forward mark sales, the Bundesbank halted these operations (Bulletin, October 1971, 791).

The Bundesbank again tried to fine-tune its credit conditions. On 31 March 1971, the Bundesbank cut its discount and Lombard rates a full percentage point, but simultaneously reduced banks rediscount quotas by 10 percent (Bulletin, October 1971, 791). Credit conditions were little changed and speculative pressures on the mark intensified. "Within three days, the Federal Bank [Bundesbank] took in more than $\$ 1.3$ billion in holding the spot mark at the ceiling and swapped some $\$ 600$ million of this inflow out in the market for three months' delivery" (Bulletin, October 1971, 792). The funds swapped out ended up back in the market.

In April, the Bundesbank reinstituted three-month forward sales of German marks. This time, however, the Bundesbank operated in the Frankfurt market, and the Federal Reserve undertook similar forward mark sales for the Federal Reserve's account in the New York market. At this time, Eurodollar interest rates began to increase, while German rates began to ease. The spot mark rate moved off its ceiling. The Federal Reserve continued concerted forward interventions nearly every day through April 1971, with the Bundesbank selling a total $\$ 1.5$ billion equivalent marks and the Federal Reserve selling \$75.7 million equivalent marks (Bulletin, October 1971, 792). The Federal Reserve covered its operations with existing mark balances and with a \$60 million swap drawing on the Bundesbank (Bulletin, October 1971, 792). The Bundesbank ceased these operations on 28 April 1971 
(Solomon 1982, 179). Although the operations "calmed" the market and may have brought the spot rate off of the ceiling, strong pressure on the mark quickly resumed. In part, reports of an European Economic Community (EEC) meeting on 16 April 1971 fanned speculative embers. At this meeting, German Minister Schiller proposed that the European currencies float or revalue together against the dollar, and Minister d'Estaing advocated a dollar devaluation (Solomon 1982, 179). During the first four months of 1971, Germany acquired $\$ 3.0$ billion and at the end of April had outstanding forward commitments of $\$ 2.7$ billion (Bulletin, October 1971, 792).

In early May 1971, leading German economic research institutes recommended floating or revaluing the mark, and many German officials gave their suggestion a sympathetic ear (Coombs 1976, 213). Speculative flows into Germany then intensified. "The German central bank was forced to buy dollars in mounting volume: more than $\$ 1$ billion on May 3 and 4 and a further $\$ 1$ billion in the first 40 minutes of trading on May 5, at which point it withdrew from the market." (Bulletin, September 1971, 784.) The Bundesbank stopped intervening. Foreign exchange trading in Frankfurt effectively ended for the next week. Austria, Belgium, the Netherlands, and Switzerland also ceased official operations. The mark began to appreciate in other markets. On 9 May 1971, Germany indicated that it would no longer defend the parity limits although formally Germany kept the parity in place. The Bundesbank would now focus policy on keeping inflation low. The mark continued to appreciate until early June.

In June, the mark started to turn around, and the Bundesbank began a series of spot dollar sales. These helped German monetary authorities to tighten monetary policy. "By mid-June the authorities had sold $\$ 1.7$ billion, considerably more than they had taken in under maturing forward contracts from the operations in February and March" (Bulletin, October 1971, 793). With the exchange rate less of a constraint on domestic policy, the Bundesbank substantially increased reserve requirements on banks' domestic and foreign liabilities. Interest rates in Germany rose. "Overall, from June 3 through the end of July, the Federal Bank [Bundesbank] sold $\$ 4.8$ billion in the spot market while it took in a total of $\$ 2.7$ billion through maturing forward contracts" (Bulletin, September 1971, 793). This respite in foreign exchange market proved short-lived, and the Bundesbank stopped selling dollars. By early August 1971, the spot mark reached a level 7.6 percent above its previous parity ceiling.

\subsubsection{The Unraveling, 1971-1973}

Nixon's actions on 15 August 1971 sent shock waves through the international community. European exchange markets remained closed for a week, and when they reopened, European governments did not defend their par values. Restraints on cross-border financial flows began to emerge. Monetary officials feared a collapse of international monetary relations amid the 
uncertainty about exchange rates, the imminent spread of protectionism, and the looming prospects of recession. IMF officials immediately pressed for negotiations to revamp exchange-rate parities and address other perennial complaints about Bretton Woods (de Vries 1976, 531-56). With respect to any future international monetary system, leaders wanted a return to fixed exchange rates, although in a system with wider margins around parities. The central role of the dollar, the role of gold, shared responsibility for exchange rate adjustment, and measures to deal with volatile financial flows were also raised (de Vries 1976, 531-56; FOMC Memoranda, 21 September 1971, 5). Negotiations proceeded over the next four months.

On 17 and 18 December 1971, monetary authorities from the Group of Ten countries met at the Smithsonian Institution in Washington, DC. The participants agreed to an 8.57 percent hike in the official gold price from $\$ 35$ per ounce to $\$ 38$ per ounce. The Swiss franc, the Italian lira, and the Swedish krona were also devalued slightly against gold, while the German mark, Japanese yen, Dutch guilder, and Belgian franc were revalued somewhat. The British pound and the French franc remained at their previous parities, and the Canadian dollar continued to float. The net effect was roughly a 10.7 percent average devaluation of the dollar against other key currencies (de Vries 1976, 555). In addition, the Smithsonian Agreement specified wider margins for currencies around their new central parities. Any currency could move $21 / 4$ percent on either side of its central parity relative to its intervention currency - typically US dollars. This implied that currencies could diverge by as much as $41 / 2$ percent against most other currencies. Further discussions toward reforming Bretton Woods were promised.

The Smithsonian Agreement did little to restore confidence in the Bretton Woods system, in part because governments still had to ratify the agreement. Funds, however, did not immediately return to the United States, and other countries continued to accumulate reserves as they attempted to defend their parities (IMF 1972, 2; Coombs 1976, 233). Germany and Japan also imposed further controls on financial flows, while others threatened similar actions (Bulletin, September 1972, 774). Moreover, the prospects of further dollar devaluation loomed large (Silber 2012, 94, de Vries 1976, 549). Following fifteen months of near constant uncertainty and turmoil, Bretton Woods collapsed. ${ }^{84}$

\subsection{Outstanding Obligations from Swaps and Bonds}

At the end of August 1971, the Federal Reserve had outstanding swap obligations totaling approximately $\$ 3.0$ billion in UK pounds, German marks, Swiss francs, and Belgian francs (Task Force 1990e, Paper no. 10, 21). The Treasury had outstanding obligations totaling nearly $\$ 1.8$ billion in German marks and Swiss francs, which, with the closing of the gold window, the Treasury could not extinguish with gold sales (Task Force 1990e, 
Paper no. 10,21). The revaluation clauses that were typical in swap drawings and Roosa bonds did not apply to a move from fixed parities to floating rates, since it was hard to determine if a creditor country appreciated or if a debtor country depreciated. The revaluation clauses only pertained to situations in which the creditor country revalued its currency. In 1972, the position emerged that if all of the G10 currencies appreciated together, that would imply a dollar depreciation (FOMC Memoranda, 19-20 March 1973, 63). Suppose, however, that one currency appreciated by more or less than the G10 average. Should the revaluation clause apply, and how should it apply? The situation was unclear. Without the revaluation clauses or some form of risk sharing, the United States faced a substantial loss on its outstanding obligations.

The Federal Reserve did not experience much difficulty in paying down its German mark and UK pound obligations. It had acquired marks through a swap drawing in May 1971 to cover some current forward positions. The desk acquired marks both from the market and from a central bank to pay off its swap debt by July 1972. Likewise, the Federal Reserve bought sterling in the market and extinguished its debts when the pound came under strong downward pressure in July and August 1972 (FOMC Memoranda, 18 July 1972, 17-18).

The Federal Reserve had more difficulty in extinguishing its Belgian and Swiss franc obligations. In part, this resulted because the Belgian franc and Swiss franc were often strong in the market, and the National Bank of Belgium and the Swiss National Bank did not want market purchases that would encourage further appreciation. Some of the $\$ 600$ million worth of Belgian debt was repaid in 1971 and 1972 when the Federal Reserve made small periodic franc purchases at the request of the National Bank of Belgium. In December 1973, however, the Federal Reserve halted such purchases when the Treasury sought to clarify the issue of risk sharing with both of these central banks and, therefore, the terms of debt repayment. The Treasury wanted equal sharing, but the Belgians "interpreted this request as a change in the original agreement and felt no obligation to comply" (Task Force 1990e, Paper no.10, 23).

After delaying, the Federal Reserve reached an agreement with the National Bank of Belgium. "In December 1975, the [Federal Reserve] System and the National Bank of Belgium agreed to adjust the outstanding swap debt to take into account the revaluation of the Belgian franc in 1971, and the two devaluations of the dollar in 1971 and 1973" (Task Force 1990e, Paper no. 10,23). As a consequence, the Federal Reserve's outstanding swap debt was increased by $\$ 54.1$ million. Near the end of 1975, with the Belgian franc-US dollar exchange rate at a level that made losses associated with the remaining liability small, the Federal Reserve began a series of Belgian franc purchases. By November 1976, the central bank had liquidated the Belgian franc debt. 
In August 1971, the Federal Reserve had $\$ 1.0$ billion in outstanding swap obligations with the Swiss National Bank, the full amount of the line, and $\$ 600$ million in outstanding Swiss franc swap obligation to the BIS. Over the next four years, the Federal Reserve made periodic purchases of Swiss francs both in the market and from the Swiss National Bank to retire this debt. In December 1975, the Federal Reserve added \$196 million worth of francs to its outstanding swap debt with the SNB to reflect losses associated with two dollar devaluations. ${ }^{85}$ Shortly thereafter, the Federal Reserve and Treasury reached a loss sharing agreement with the Swiss National Bank. In February 1976, the Federal Reserve drew $\$ 600$ million on the Swiss National Bank swap line to pay down the BIS Swiss franc line completely. Then in October 1976, the Federal Reserve undertook an unusual transaction to pay down the entire line with the Swiss National Bank. The Federal Reserve negotiated a new "special" swap line with the SNB that embodied the risk sharing agreement and set a three-year timetable for repayment. The Swiss National Bank also agreed to sell the Federal Reserve and the US Treasury Swiss francs if necessary. The Federal Reserve paid off the original swap with a drawing on this special swap, and paid off the special line by April 1979. The Treasury also paid off its outstanding Swiss franc obligations in April 1979.

The Federal Reserve and the Treasury took seven and a half years to pay off its pre-August 1971 swap obligations. The estimated losses to the Federal Reserve and to the Treasury on these outstanding debts were $\$ 986$ million and $\$ 1.5$ million, respectively (Task Force 1990e, Paper no. 10, 25).

\subsection{Conclusion}

The Bretton Woods system flew in the face of the fundamental trilemma of international finance, because it attempted to credibly maintain fixed exchange rates and free financial flows, but also allowed some deviations from these desired objectives to promote domestic macroeconomic goals. When these ideals came into serious conflict by the early 1970s, national governments opted to promote domestic objectives for price stability and full employment over exchange-rate stability and free financial flows.

In hindsight, that conflict seemed inevitable. Triffin's paradox fundamentally threatened the Bretton Woods system. Although efforts to repair this basic flaw - to provide a source of liquidity not based on US balanceof-payments deficits - got underway in the mid-1960s, a high US inflation rate and inevitable cross-rate adjustment problems overtook these efforts. By 1971, Bretton Woods was quickly unraveling. By 1973, it was gone. Floating exchange rates were the predictable consequence of countries' unwillingness to make domestic economic objectives - price stability and full employment-subservient to the maintenance of par values.

United States foreign-exchange-market operations during Bretton Woods often worked as designed; they regularly provided a solution to tem- 
porary, reversible balance-of-payments disequilibria. Very often, however, the operations failed to distinguish between temporary and fundamental disequilibria situations, and they did not address the system's deep-seated weaknesses. Consequently, they arguably may have prolonged and worsened the inevitable breakdown of Bretton Woods.

The US institutional mechanisms for foreign-exchange-market interventions survived the collapse of Bretton Woods and would adapt to a floating exchange-rate environment. The fundamental reservations about these operations - ultimately their potential threat to Federal Reserve independence-would also remain. Attitudes about these reservations, however, would evolve along with thoughts about the proper role of monetary policy before intervention itself was abandoned as a threat to monetary credibility. 